\title{
21. MESOZOIC AND CENOZOIC CALCAREOUS NANNOFOSSILS RECOVERED BY DEEP SEA DRILLING PROJECT LEG 71 IN THE FALKLAND PLATEAU REGION, SOUTHWEST ATLANTIC OCEAN ${ }^{1}$
}

\author{
Sherwood W. Wise, Jr., Department of Geology, Florida State University, Tallahassee, Florida
}

\begin{abstract}
Three continuously cored DSDP Leg 71 sites drilled in the high latitudes of the southwestern Atlantic Ocean yielded thick sections of nannofossil-bearing sediments of Late Jurassic, Cretaceous, and Tertiary age. Oxfordian-lower Tithonian, Albian, upper Turonian-Maestrichtian, and middle Eocene-Oligocene assemblages are reasonably diverse for these latitudes and generally well preserved. Long sections of Santonian to lower Campanian, middle Eocene, and Oligocene strata add substantially to the record of nannofossiliferous sediments recovered from this region by the previous Glomar Challenger cruise to the area, DSDP Leg 36.

High-latitude provincial forms are common in the Cretaceous and Tertiary sections and have prompted the proposal of new zones or subzones for the Barremian-Aptian, Albian, Coniacian-Turonian, and Oligocene. Severe climatic conditions limit post-Oligocene coccolith assemblages to fewer than one dozen species; thus zonations remain virtually unworkable for that part of the column in this area.

Exceptional preservation of many assemblages aided in the recognition of new taxa, including Reticulofenestra bisecta filewiczii, n. ssp., Chiasmolithus solitus inversus, n. var., Broinsonia parca expansa, n. ssp., Cretarhabdella bergenii, n. sp., Crucicribrum striatum constansii, n. ssp., Petrarhabdus, n. gen., and Thiersteinia ecclesiastica n. gen., n. sp. Long sections and good preservation also prompted some speculations concerning the phylogeny of groups such as the Broinsonia parca plexus.
\end{abstract}

\section{INTRODUCTION}

Leg 71 of the Deep Sea Drilling Project was the fifth cruise of the Glomar Challenger to the high latitudes of the Southern Ocean and the second to the area of the Falkland Plateau. A total of 173 rotary drill and hydraulic piston cores containing 824 meters of sediment were taken at four sites, two on the Falkland Plateau and two to the east northeast on the lower flank of the Mid-Atlantic Ridge (Figs. 1 and 2).

Significant numbers of calcareous nannoplankton were recovered at DSDP Sites 511, 512, and 513, which were continuously cored. The new sections recovered complement well sequences obtained previously during DSDP Leg 36, which interval-cored Sites 327, 329, and 330 on the Falkland Plateau (Fig. 1). The Falkland Plateau is an intermediate-depth aseismic feature which extends some $1000 \mathrm{~km}$ east across the southwest Atlantic from the Falkland Islands. It has now yielded the most extensive record of Jurassic to Recent carbonate-bearing marine sediments yet available for study from this region. These sediments provide an excellent opportunity to study the biostratigraphic and biogeographic distribution of calcareous nannofossils from the higher latitudes of the Southern Hemisphere. These sequences are especially attractive for coccolith studies, because favorable lithologies and the exposure of relatively old stratigraphic units near the surface under low overburden pressures have enhanced the preservation of older nannofossil assemblages.

${ }^{1}$ Ludwig, w. J., Krasheninnikov, v. A., et al., Init. Repts. DSDP, 71: Washington (U.S. Govt. Printing Office).
Stratigraphic and biogeographic studies of DSDP Leg 36 coccoliths were carried out initially by Wise and Wind (1977) and by Haq, Lohmann, et al. (1977). The Leg 36 nannofossil assemblages have since provided an important benchmark for regional or worldwide biogeographic coccolith studies by Haq, Perch-Nielsen, et al. (1977), Wind (1979a, b), Haq (1980), Roth and Bowdler (1981), and Thierstein (1981). Noël and Manivit (1978) drew on material from Sites 327 and $\mathbf{3 3 0}$ for a comparative nannofacies study of the Mesozoic black shales of the South Atlantic and Wise (1977) used Site 330 material in his study of early chalk diagenesis. Wind and Wise (1978) used Site 327 samples to help document their discovery of Mesozoic holococcoliths.

Coccoliths encountered during subsequent piston core studies of the Falkland Plateau have been noted by Ciesielski et al. (1977), Ciesielski and Wise (1977), and Wise (1981). Wise et al. (1982) summarized the paleoenvironmental history of the Falkland Plateau, using paleontologic and sedimentologic data from all sources available prior to DSDP Leg 71.

In addition to the descriptions of the Leg 71 coccolith assemblages given here, other chapters in this volume of the Initial Reports give information on various aspects of the Falkland Plateau nannofloras. Wind and Wise discuss and correlate upper Campanian-Maestrichtian assemblages, and Parker et al. analyze nanno chalk carbonate cycles in the Aptian-Albian black shales. Wise and Mostajo illustrate well-preserved, correlative Eocene-Oligocene nannofloras sampled in piston cores from the Plateau. Another companion paper (MacKenzie and Wise) deals with Paleogene nannofloras from DSDP holes south and east of South Africa that provide a look at temperate assemblages for comparison with 


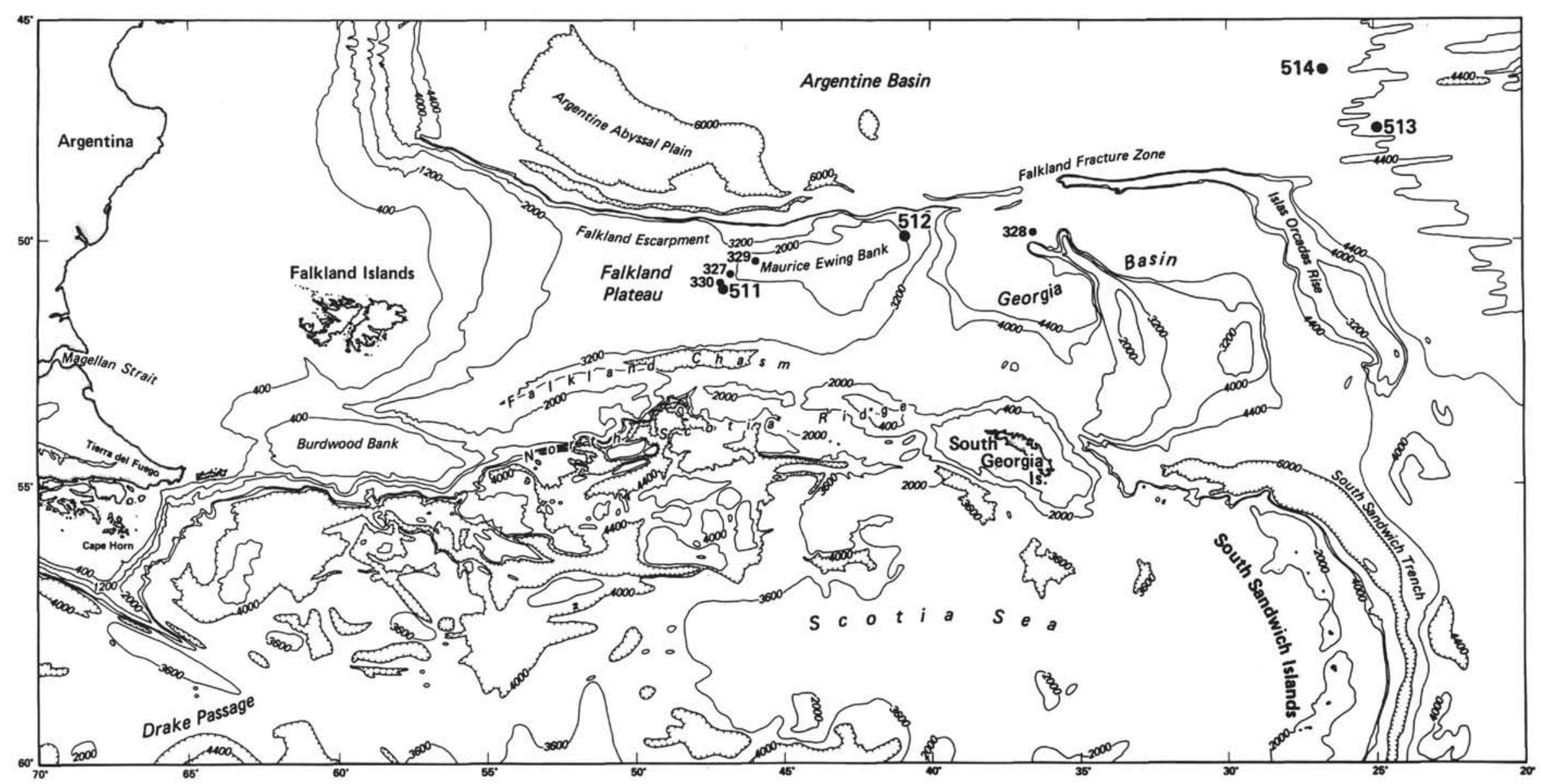

Figure 1. Site locations, DSDP Leg 71. 

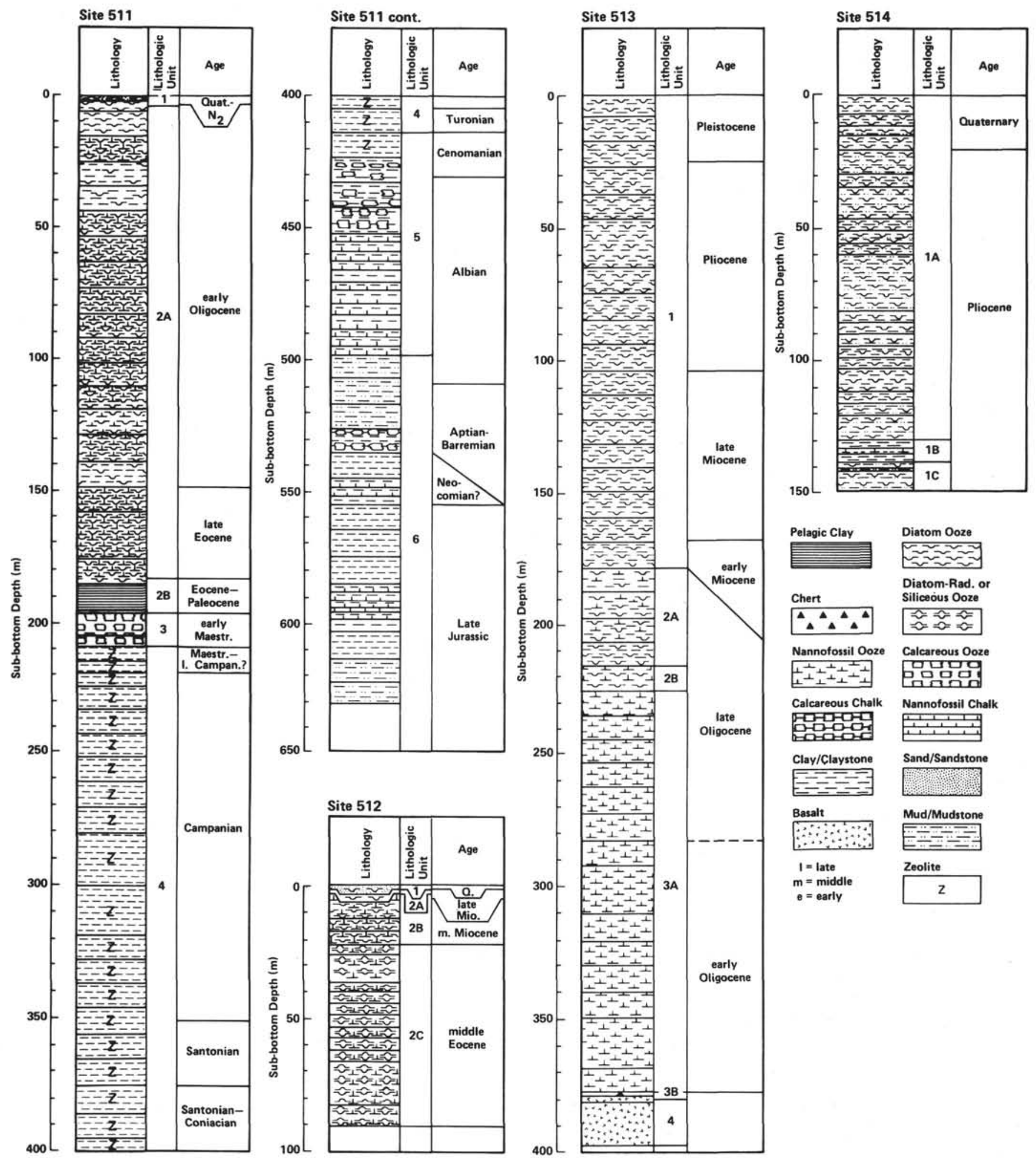

Figure 2. Lithologic columnar sections, DSDP Leg 71 sites.

the higher latitude floras sampled by DSDP Legs 36 and 71. Much regional paleoenvironmental information on the high-latitude Falkland Plateau nannofloras is already available in the publications already cited; therefore, this chapter will discuss primarily stratigraphic and taxonomic aspects of the Leg 71 nannofloras and will offer some speculations on the evolution of certain groups. Of particular interest are assemblages from intervals not previously sampled in the area. Much of the description and many of the illustrations are devoted to coccoliths from these newly sampled sequences.

Because of the highly episodic nature of sedimentation on the Falkland Plateau and the presence of numerous hiatuses in the section, completely different strati- 
graphic units, highly variable in thickness, can be sampled within the Upper Cretaceous-Tertiary despite relatively short distances (10 to $100 \mathrm{~km}$ ) between drill sites. Sections sampled on the Plateau during Leg 71 for the first time ever or for the first time to any appreciable extent include the Turonian, Coniacian-Santonian, lower Campanian, middle Eocene, upper Eocene, and lower Oligocene. In addition, a major gap was partially filled within the upper Campanian-Maestrichtian section. At Site 513 on the flank of the Mid-Atlantic Ridge, a nearcomplete Oligocene section was sampled; its base overlaps the lower Oligocene section drilled at Site 511 on the Falkland Plateau. The upper Oligocene at Site 513 is far more extensive and better preserved than a more lithified section drilled at Site 329 on the Plateau during Leg 36.

The zonation, biostratigraphy, and systematic paleontology of calcareous nannofossils recovered are discussed in detail in subsequent sections of this chapter. The species considered are listed in Appendix A, where they are arranged alphabetically by specific and generic epithets (parts A and B, respectively). Most bibliographic references for these taxa are presented by Loeblich and Tappan $(1966,1968,1969,1970 a, 1971,1973)$ or by Heck (1979a, b, 1980a, b, 1981a, b, 1982); any not included therein are given in the references.

Austral taxa. Some of the taxa studied are endemic to or flourished in cooler waters, and these provide useful information not only for local stratigraphy, but also for paleobiogeographic and phylogenetic studies. Forms confined to the high latitudes are often bipolar. These and other Austral forms have have been discussed by Wise and Wind (1977), Wind (1979a, 1979b), Haq, Lohmann, et al. (1977), Haq, Perch-Nielsen et al., (1977), Haq (1980), Thierstein (1981), Roth and Bowdler (1981), and others. The important Austral species encountered in the region of the Falkland Plateau during Legs 36 and 71 are listed in Appendix B.

A summary of coccolith occurrences by site measured against low-latitude biostratigraphic zonations compiled by Bukry (1973a), Thierstein (1973), and Roth (1978) is given in Figure 3; Figure 4 gives a summary of datum levels and zones adopted in this chapter for use in the range charts and lithologic logs (see site chapters, this volume). Most of the datum levels used for this study have been defined during numerous investigations conducted over the past fifteen years. Those used here are chosen whenever practical from the low-latitude zonations just mentioned to facilitate long-range correlation. Ecologic restraints and provincialism among the high-latitude floras of Leg 71 are such, however, that it is not unusual for low-latitude index forms to be rare or absent. It became apparent that regional studies in this area would be facilitated by a zonation that employs some provincial or secondary marker species which are numerous and easily identified in these sediments. The zonation adopted for this report, therefore, is a compromise between the needs of long-range and regional correlation.

\section{ZONATION}

As with other calcareous planktonic organisms, coccoliths attain their maximum diversity in the tropics. As noted earlier, many tropical forms used as guide fossils are not found in the higher latitudes, nor are they systematically replaced poleward by other taxa endemic to cooler waters, as is the case with most siliceous planktonic microfossil groups. For this reason, the number of usable coccolith index species decreases with increasing latitude, and zonal intervals must be expanded poleward, with a consequent loss of biostratigraphic resolution. As noted by others who have participated in highlatitude DSDP legs, this problem is most acute for Neogene coccoliths. The general climatic deterioration which occurred during the late Cenozoic resulted in a contraction of climatic belts and a steepening of temperature gradients poleward. From the Miocene onward low-latitude coccolith zonations are essentially useless for Falkland Plateau material. For most of the long Jurassic-Cretaceous interval, during a time when global climates were generally more equitable, tropical zonations can be applied to the Falkland Plateau sequence without much difficulty. It is convenient, however, to use common and easily recognized provincial markers either for subzones or for an alternate set of zones for purposes of local correlation. For this reason, a number of provincial zonal units have been established to be used in lieu of or in conjunction with the well-defined low-latitude zonal schemes. Some of these provincial units were outlined previously by Wise and Wind (1977) or Wind (1979a). New units established herein or units whose definitions have been modified from previous usage are listed here.

\section{Cenozoic}

The Oligocene zones listed here are all based on last evolutionary occurrences. In the high latitudes, as forms became extinct during the Oligocene, there were no newly evolved cool-water species to replace them. This trend reflects the deteriorating climatic conditions of the polar regions at this time.

\section{Reticulofenestra bisecta Zone}

Definition. Interval from the last common uphole occurrence of Chiasmolithus altus to the LAD (last appearance datum) of Reticulofenestra bisecta .

Reference locality. Hole 513A, 198 to 218 meters.

\section{Chiasmolithus altus Zone}

Definition. Interval from the LAD of Reticulofenestra umbilica to the last common uphole occurrence of Chiasmolithus altus.

Reference locality. Hole 513A, 218 to 326 meters.

\section{Reticulofenestra daviesii Zone}

Definition. Interval from the LAD of Clausicoccus fenestratus to the LAD of Reticulofenestra umbilica. Reference locality. Hole 513A, 327 to 337 meters. 
A

\begin{tabular}{|c|c|c|c|c|c|c|}
\hline \multirow[b]{2}{*}{ Age } & \multirow{2}{*}{$\begin{array}{c}\text { Bukry } \\
\begin{array}{c}\text { Zone- } \\
\text { Subzone }\end{array}\end{array}$} & \multicolumn{5}{|c|}{ This Study } \\
\hline & & $\begin{array}{l}\text { Site } \\
511\end{array}$ & $\begin{array}{l}\text { Site } \\
512\end{array}$ & $\begin{array}{l}\text { Site } \\
513\end{array}$ & $\begin{array}{l}\text { Site } \\
514\end{array}$ & $\begin{array}{l}\text { Falkland Plateau } \\
\text { Zone-Subzone }\end{array}$ \\
\hline \multirow{5}{*}{ 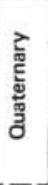 } & CN15 & $1-1$ & 1.1 & & \multirow{11}{*}{$1-1 / 35, \mathrm{CC}$} & Emiliania huxleyi \\
\hline & CN14b & & & & & \\
\hline & CN14a & & & & & \\
\hline & CN13b & & & & & \\
\hline & CN13a & & & & & No zone \\
\hline \multirow{9}{*}{ 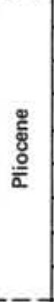 } & CN12d & & & & & (diatom correlation) \\
\hline & CN12c & & & & & \\
\hline & CN12b & & & & & \\
\hline & CN12a & & & & & \\
\hline & CN11b & & & & & \\
\hline & CN11a & & & & & \\
\hline & CN10d & & & & & \\
\hline & CN10c & & & & & \\
\hline & CN10b & & & & & \\
\hline \multirow{15}{*}{ 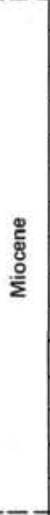 } & CN10a & & & & & \\
\hline & $\mathrm{CN} 9 \mathrm{~b}$ & & & & & \\
\hline & $\mathrm{CN9a}$ & & & & & \\
\hline & CN8b & & \multirow{4}{*}{$1-1 / 6-1$} & & & \multirow{4}{*}{$\begin{array}{c}\text { No zone } \\
\text { (diatom correlation) }\end{array}$} \\
\hline & CN8a & & & & & \\
\hline & CN7b & & & & & \\
\hline & CN7a & & & & & \\
\hline & CN6 & & & & & \\
\hline & CN5b & & & & & \\
\hline & CN5a & & & & & \\
\hline & CN4 & & & & & \\
\hline & CN3 & & & & & \\
\hline & CN2 & & & & & \\
\hline & CN1c & & & & & \\
\hline & CN1b & & & & & \\
\hline \multirow{8}{*}{ 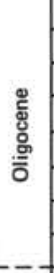 } & CN1a & & & $13 \mathrm{~A} \cdot 1 / 14 \mathrm{~A}-2$ & & Cyclicargolithus abisectus \\
\hline & CP19b & & & $14 \mathrm{~A} \cdot 6 / 16, \mathrm{CC}$ & & Reticulofenestra bisecta \\
\hline & CP19a & & & \multirow{3}{*}{$17 A-1 / 28 A-3$} & & \multirow{3}{*}{ Chiasmolithus altus } \\
\hline & CP18 & & & & & \\
\hline & CP17 & & & & & \\
\hline & CP16c & $2-3 / 3, \mathrm{CC}$ & & $28 \mathrm{~A} \cdot 4 / 29 \mathrm{~A}, \mathrm{CC}$ & & Reticulofenestra daviesii \\
\hline & CP16b & $4-1 / 4-3$ & & 30A-1/30A,CC & & Clausicoccus fenestratus \\
\hline & CP16a & $4, \mathrm{CC} / 16-2$ & & & & Blackites spinosus \\
\hline \multirow{4}{*}{ 总 } & CP15b & $17 \cdot 1 / 20-3$ & & & & Reticulofenestra oamaruensis \\
\hline & CP15a & \multirow{3}{*}{${ }_{i}^{21-1 / 22, c c} ?$} & & & & \\
\hline & CP14b & & & & & \\
\hline & CP14a & & $6-1 / 19, C C ; 2 A$ & & & Discoaster bifax \\
\hline
\end{tabular}

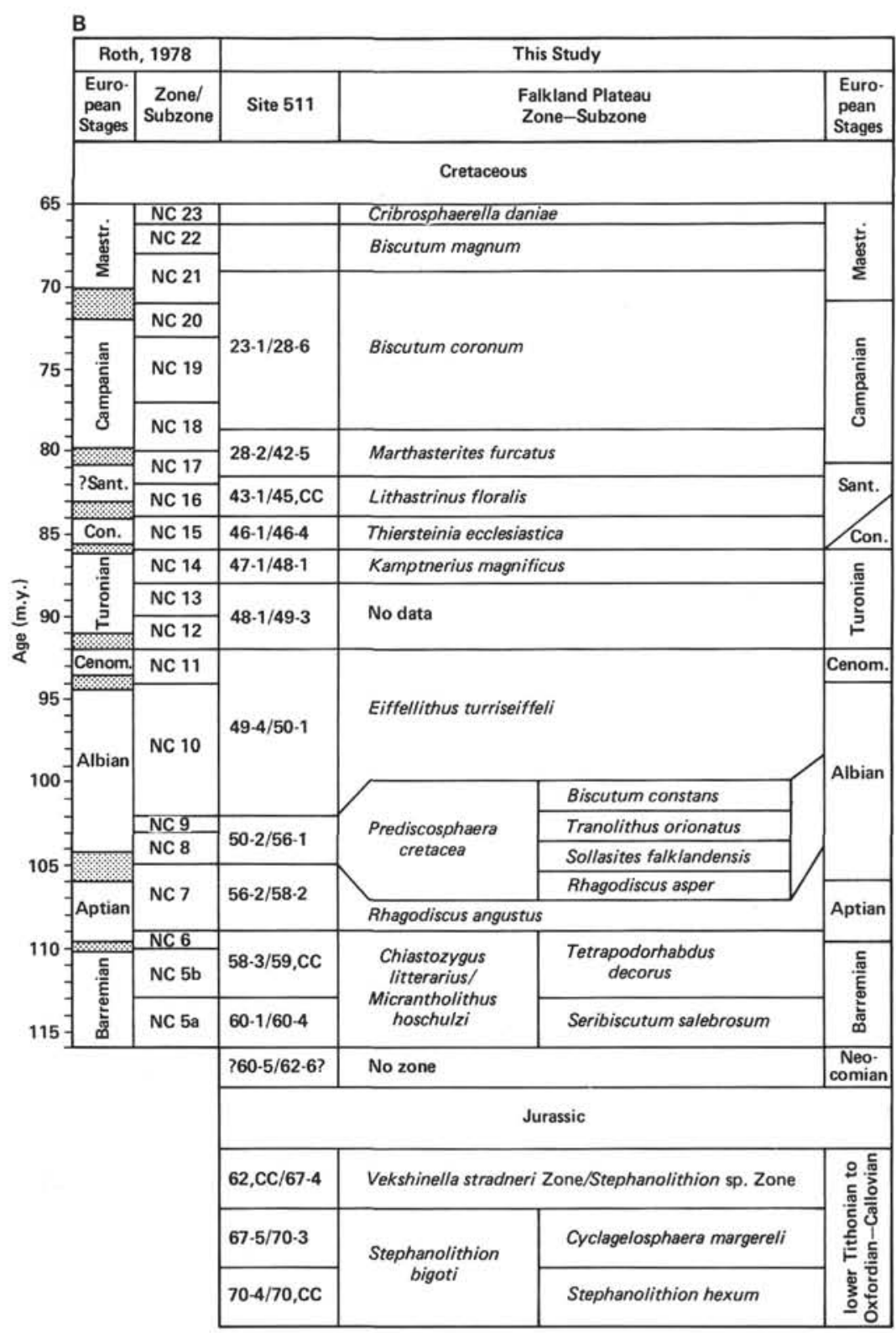

Figure 3. Zonal and geologic age assignments: (A) Cenozoic calcareous nannofossil assemblages in DSDP Leg 71 cores, measured against standard low- or middle-latitude zonation for the Cenozoic by Bukry and coworkers (Bukry, 1973a; Okada and Bukry, 1980). (A indicates cores from Holes 512A and 513A.) (B) Mesozoic calcareous nannofossil assemblages in DSDP Leg 71 cores, measured against the low- or middle-latitude zonation for the Cretaceous compiled by Roth (1978). 


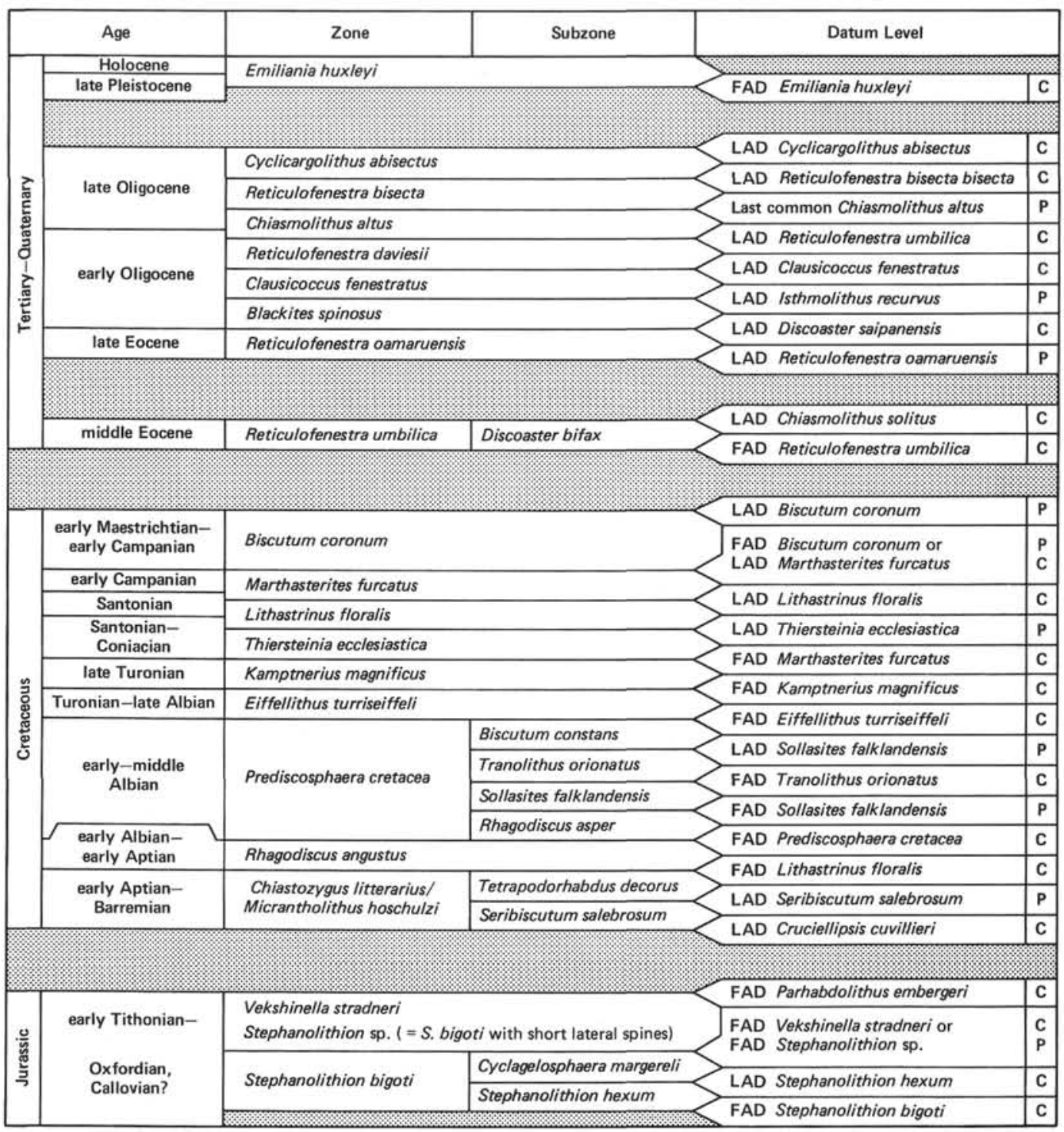

Figure 4. Calcareous nannofossil zones used in this chapter. ( $\mathrm{C}=$ cosmopolitan, $\mathrm{P}=$ middle- or high-latitude provincial species.)

\section{Clausicoccus fenestratus Zone}

Definition. Interval fronı the LAD of Isthmolithus recurvus to the LAD of Clausicoccus fenestratus.

Reference locality. Hole 511, 24 to 27 meters.

\section{Mesozoic}

\section{Biscutum coronum Zone}

Definition. Interval from the LAD of Marthasterites furcatus and the FAD (first appearance datum) of $\mathrm{Bi}$ scutum coronum to the LAD of Biscutum coronum.

Reference locality. None at present (see Remarks).

Remarks. Wind (1979a) originally defined this zone as the total range of Biscutum coronum. At that time, little was known about the Santonian to upper Campanian of the high southern latitudes; thus the range of $B$. coronum was unknown and no reference section was given. From the present study it appears that the FAD of $B$. coronum is in the lower Campanian (Section 51128-5, Table 1B, later). The record at Site 511, however, is incomplete because dissolution resulting from a high calcium carbonate compensation depth prevented the deposition of nannoliferous sediment during most of Campanian time. Just above the FAD of $B$. coronum is noted the last appearance of Marthasterites furcatus in Sample $511-28-2,115 \mathrm{~cm}$, which contains only dissolution-resistant coccoliths. The range of that species in this section, therefore, appears to have been truncated by dissolution. It does seem to overlap to some unknown extent the range of $B$. coronum as indicated by their co-occurrence over an interval of some meters in Core 511-28. The preservation of the section is generally poor, however, and the ranges of these and other potentially important index species in the middle and upper Campanian are virtually unknown in this part of the world (examples, the LAD of Seribiscutum primitivum and Amphizygus? sp.). Rather than selecting only one 
marker for the base of the B. coronum Zone, therefore, I choose to specify two. These datums may actually be quite close together in time. The present ambiguity in the succession of these and the other datums mentioned will, I hope, be resolved through further investigation of this part of the high-latitude section.

\section{Marthasterites furcatus Zone}

Definition. Interval from the LAD of Lithastrinus floralis to the LAD of Marthasterites furcatus and the FAD of Biscutum coronum.

Reference locality. Hole 511, 226 to 363 meters.

Remarks. Both boundaries modified from Čepek and Hay (1969) to meet local requirements. The topmost portion of this zone is probably not represented at Site 511 since the section becomes barren of calcareous nannofossils upsection in the lower Campanian.

\section{Lithastrinus floralis Zone}

Definition. Interval from the LAD of Thiersteinia ecclesiastica to the LAD of Lithastrinus floralis.

Reference locality. Hole 511, 336 to 389 meters.

\section{Thiersteinia ecclesiastica Zone}

Definition. Interval from the FAD of Marthasterites furcatus to the LAD of Thiersteinia ecclesiastica.

Reference locality. Hole 511, 396 to 399 meters.

\section{Kamptnerius magnificus Zone}

Definition. Interval from the FAD of Kamptnerius magnificus to the LAD of Thiersteinia ecclesiastica.

Reference locality. Hole 511, 404 to 414 meters.

Remarks. The upper boundary is modified from Roth's (1978) zone of the same name, which is at a different stratigraphic level than is the Kamptnerius magnificus Zone of Cepek and Hay (1969).

\section{Sollasites falklandenis Subzone of the Prediscosphaera cretacea Zone}

Definition. Interval from the FAD of Sollasites falklandensis to the FAD of Tranolithus orionatus.

Reference locality. Hole 511, 446 to 482 meters.

Remarks: Modified from Wise and Wind (1977) by alteration of the lower boundary.

\section{Rhagodiscus asper Subzone of the Prediscosphaera cretacea Zone}

Definition. Interval from the FAD of Prediscosphaera cretacea to the FAD of Sollasites falklandensis.

Reference locality. Hole 511,471 to 482 meters.

Remarks. A new subzone established from the continuously cored section at Hole 511. At DSDP Holes $327 \mathrm{~A}$ and 330 , it had not been possible to ascertain the FAD of Sollasites falklandensis because of discontinuous coring.

Tetrapodorhabdus decorus Subzone of the Chiastozygus litterarius/Micrantholithus hoschulzi Zone

Definition. Interval from the LAD of Seribiscutum salebrosum to the FAD of Lithastrinus floralis.

Reference locality. Hole 511, 513 to 524 meters.
Remarks. Seribiscutum salebrosum is a high-latitude form whose stratigraphic range is not well established, and therefore this subzone is highly tentative. The form identified here as $S$. salebrosum may also have undergone diagenetic alteration. Nevertheless, it is distinctive and readily identified in the local section. In nearly all instances where it has been used (example, Sissingh, 1977), the Micrantholithus hoschulzi (=Micrantholithus obtusus) Zone or Subzone is an interval zone which covers the upper Barremian. No attempt was made here to differentiate it from Thierstein's (1973) Chiastozygus litterarius Zone. Flabellites oblongus does not occur in this part of the Falkland Plateau section; therefore the zone of that name as suggested by Roth (1978) is not used here.

\section{Seribiscutum salebrosum Subzone of the Chiastozygus litterarius/Micrantholithus hoschulzi Zone}

Definition. Interval from the LAD of Cruciellipsis cuvillieri to the LAD of Seribiscutum salebrosum.

Reference locality. Hole 511, 528, to 533 meters.

Remarks. The base of this zone was not observed in Hole 511 because we encountered a barren interval and possibly a hiatus.

\section{METHODS AND PROCEDURES}

Selected samples were studied by scanning electron microscopy using procedures outlined by Wise and Kelts (1972). For samples in which coccoliths were rare or tended to occur in isolated pods (probably fecal pellets), coccoliths were located by scanning fracture sections of the rock for calcium, using the energy-dispersive X-ray system attached to the SEM. This proved especially advantageous for the Jurassic and Lower Cretaceous black shale sequences. On the range charts, occurrences of species which were determined by electron microscopy rather than by light microscopy are denoted by a double asterisk $\left(^{* *}\right)$ alongside either the sample number or the species name.

The abundances of coccolith species were tabulated on the range charts using the method proposed by Hay (1970). In the light microscope, tabulations were made using standard smear slide preparations, all examined at a magnification of $\times 1000$. Letters used on the range charts to denote coccolith abundances are keyed to the ${ }^{10} \log$ of the number of specimens of a particular taxon likely to be observed in any one field of view of the microscope. These and the corresponding logs are determined as follows: view)

E Extremely abundant, +3 (more than 1000 specimens per field of H Highly abundant, +2 (more than 100 specimens per field of view)

V Very abundant, +1 (more than 10 specimens per field of view) A Abundant, 0 ( 1 to 10 specimens per field of view)

C Common, -1 ( 1 specimen per 2 to 10 fields of view)

F Few, -2 (1 specimen per 11 to 100 fields of view)

R Rare, -3 (1 specimen per 101 to 1000 fields of view)

The abundances of reworked taxa and of downhole contaminants are denoted in lower-case letters.

\section{SITE SUMMARIES}

\section{Site 511 (Table 1)}

Site $511\left(51^{\circ} 00.28^{\prime} \mathrm{S} ; 46^{\circ} 58.30^{\prime} \mathrm{W}\right.$; water depth, 2589 $\mathrm{m})$ was located in the basin province of the Falkland Plateau about $10 \mathrm{~km}$ south of DSDP Site 330 where Leg 36 scientists drilled 567 meters of Mesozoic and Cenozoic sediment above continental basement (Barker, Dalziel, et al., 1977). The objectives of the site were to test the correlation of units penetrated at DSDP Sites 327 
Table 1A. Distribution of Eocene to Holocene calcareous nannofossils, Hole 511.

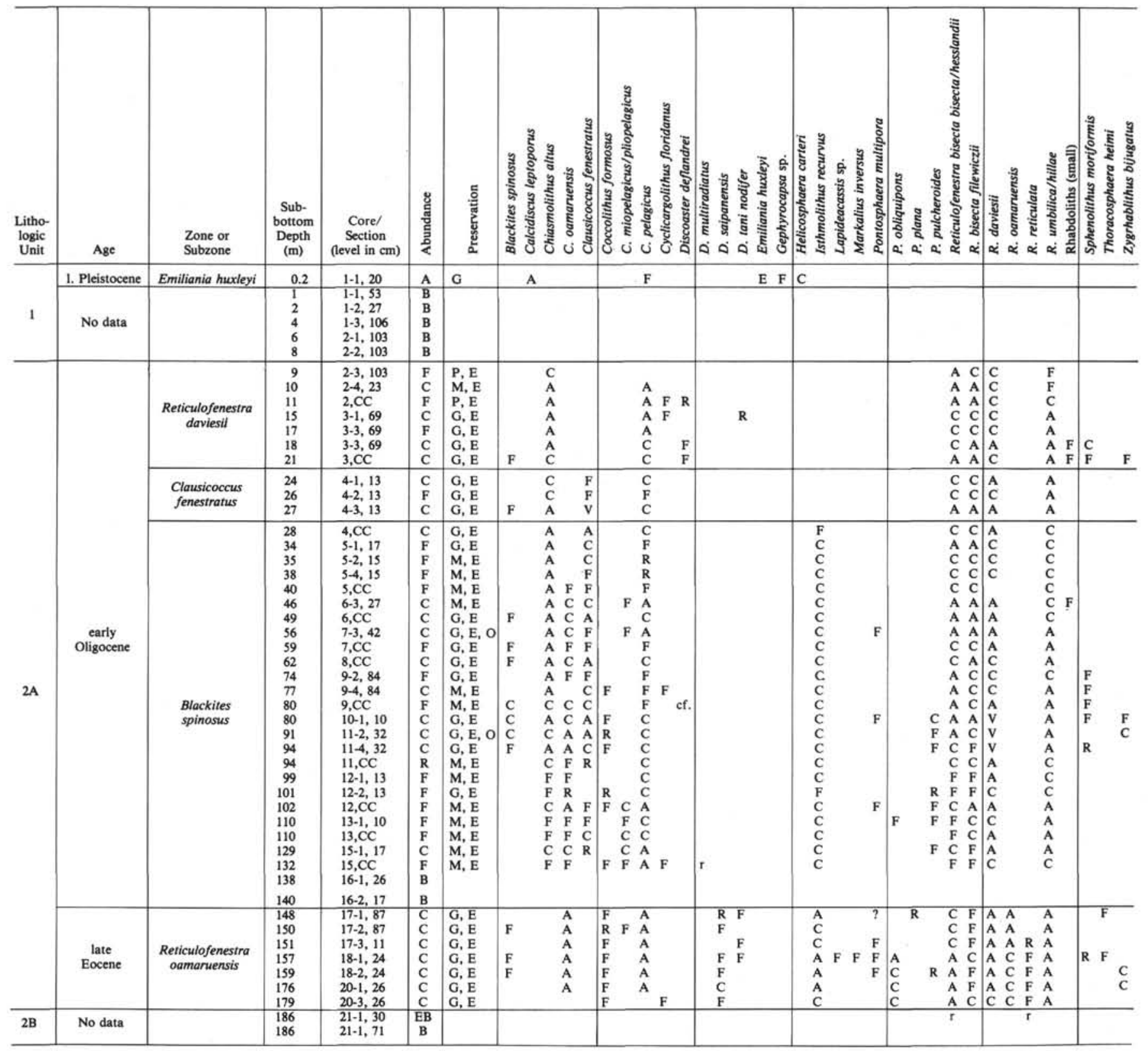

Note: Abundance is characterized by E, extremely abundant; V, very abundant; A, abundant; C, common; F, few; R, rare; B, barren; EB, essentially barren. For preservation, P, poor; M, moderate, G, good; E, etched; O, overgrown.

and 330 and to continuously core the sequence that had previously been spot-cored.

The 632.5 meter section recovered (Fig. 2) was divided into six lithologic units. Three meters of Quaternary glacial marine sediments (Unit 1) overlay an extraordinarily long (192 m) section of lower Oligocene diatomaceous oozes (Unit 2) which was largely unsampled during Leg 36 . The only equivalent material drilled previously was one core of lower Oligocene nanno chalk recovered at DSDP Site 329. Unit 3 consists of 14 meters of gray calcareous oozes of late Campanian to early Maestrichtian age. Fifty meters of this unit were penetrated at DSDP Site 327. Unit 4 is another extraordinarily long section consisting of $\mathbf{2 0 3 . 4}$ meters of gray to greenish gray zeolitic clays and claystones ranging from Coniacian to Campanian in age. The only equivalent to this section recovered previously was contained in one core (327-14) taken at DSDP Hole 327A. Lithologic Units 5 and 6 were more familiar from earlier studies, since they represented more laterally continuous sequences sampled in spot cores at DSDP Sites 327 and 330. Unit 5 consists of 80 meters of variegated to greenish gray zeolitic clays, nannofossil claystones, and muddy nannofossil chalks of early Albian to Turonian age. This was the first time Turonian strata had been sampled in this region. Unit 6 represents the top 140 meters of the extensive black mudstones of Jurassic to early Albian age sampled during Leg 36 . 
Calcareous nannofossils were few to common in amounts throughout the hole, becoming consistently abundant in the Maestrichtian/Campanian and Albian. They were generally scarce in the black mudstones, however, where assemblages were affected by the highly restricted (euxinic) paleoenvironment. Preservation is generally good, considering the thickness of the section and the age of the sediments. A relatively high carbonate compensation depth affected preservation in the Upper Cretaceous-Tertiary. Diversity was adversely affected by the high-latitude position of the site and all assemblages exhibit Austral floral compositions of the types discussed in some detail by Wise and Wind (1977).

\section{Cenozoic (Table 1A)}

In Unit 1 coccoliths were present only in a short (10 $\mathrm{cm}$ ) interval (repeated by a double hit of the drill string) at the top of the section. This assemblage, which belongs to the Emiliania huxleyi Zone, is probably Holocene in age.

Core 2 leads into a long lower Oligocene section (about $140 \mathrm{~m}$ ) in which coccoliths are few to common and divisible into three zones. Coccoliths in Cores 2 and 3 are few to common and contain assemblages of the Chiasmolithus altus Zone which are dominated by $C$. altus, Coccolithus pelagicus and a host of reticulofenestrids, including Reticulofenestra daviesii, R. umbilica, and two subspecies of $R$. bisecta. Discoasters, a group of warm-water affinity, are rare but present sporadically. Core 4 contains the last uphole occurrence of Clausicoccus fenestratus and is assigned to a new zone of that name. The rest of the assemblage is unchanged from the preceding. The bulk of the section (over $110 \mathrm{~m}$ ), from Samples $511-4, C C$ to $511-16-2,26 \mathrm{~cm}$, lies below the LAD of Isthmolithus recurvus and is assigned to the Blackites spinosus Zone. Reticulofenestrids and Chiasmolithus continue to dominate the floras and warmer water forms such as Cyclicargolithus floridanus and discoasters are virtually absent. A significant datum for local correlation is the extinction of Coccolithus formosus in Sample 511-9-4, $84 \mathrm{~cm}$. Unfortunately this species prefers warmer waters and is rare to few throughout this part of the section. Core 16 is barren of coccoliths and is assigned to the Oligocene based on ages derived from the few foraminifers present (Krasheninnikov and Basov, this volume).

The upper Eocene section penetrated in Cores 17 to 20 is highly significant because this is the first time these strata have been sampled in this region. The Oligocene/ Eocene boundary is drawn on the last occurrence of Discoaster saipanensis, which is few to rare in Core 17. The assemblages continue to be dominated by the reticulofenestrids seen earlier, with the addition of $R$. oamaruensis, which is common to abundant and serves as the name species of the upper Eocene zone. This species, plus the absence of Chiasmolithus altus s.s. and the addition of $R$. reticulata (which is rare to few below Sample $511-17-3,11 \mathrm{~cm}$ ) give the Eocene nannoflora a distinctive appearance, and one easily distinguished from the Oligocene assemblages. This distinction is undoubtedly sharpened by the barren interval in Core 16 , which creates a nannofossil hiatus that eliminates any transitional assemblage that may have linked more closely the Oligocene and Eocene nannofloras.

Within the Eocene, the extinction of $R$. reticulata may be a datum which can be used (with some difficulty because of its low abundance) for local correlation. Also important in this interval is $R$. daviesii, which dominates the small reticulofenestrids. The importance of this species in the high latitudes of the Southern Hemisphere was not appreciated prior to the examination of the Leg 71 sequences. Backman (1980) describes its occurrence in the higher latitudes of the North Atlantic.

Core 21 sampled a yellowish pelagic clay (Unit 2B) which is barren of coccoliths but which did contain some poorly preserved radiolarians and diatoms that may be late Paleocene to early Eocene in age (Site 511 site chapter this volume). Unfortunately, Core 22 contained no sediment, so little can be said about this poorly dated interval. Low accumulation rates (see Site 511 site chapter, this volume), however, suggest a disconformity between these cores and the Cretaceous sediment of Core 23. Missing in particular are 50 meters of nannoliferous upper Paleocene to lower Eocene diatomaceous oozes and zeolitic clays sampled at nearby DSDP Site 327.

\section{Cretaceous (Tables 1B and 1C)}

Core 23 and the top half of Core 24 contain an uppermost Campanian to lower Maestrichtian nannoflora dominated by cool-water assemblages assigned to Wind's (1979a) Biscutum coronum Zone. Alternatively they can be assigned to Sissingh's (1977) Reinhardtites levis and Tranolithus phacelosus Zones. These cores represented special stratigraphic and paleoenvironmental problems and are dealt with in a companion paper by Wind and Wise (this volume) which also provides range charts and illustrations of the assemblages.

Middle to upper Campanian nannofossil assemblages are essentially absent in sites sampled to date on the Falkland Plateau. This interval may be represented by the largely barren zeolitic clays in Cores 25 to 27 (Table 1B). Section 511-28-1, still within the $B$. coronum Zone, contains a few coccoliths including forms which approach in evolutionary development Broinsonia parca constricta. This taxon ranges from the lower Campanian upward at lower latitude localities (e.g., Hattner and Wise, 1980). Marthasterites furcatus and Lithastrinus grillii, however, which together are confined to the lower Campanian, are noted in Sections 511-28-2 and 511-29-1, respectively. It seems likely that the entire Core 28 is lower Campanian.

The remainder of the extraordinarily long Campanian section (about $125 \mathrm{~m}$ ), down to Sample 511-41-3, $116 \mathrm{~cm}$, contains a diverse, generally well preserved nannoflora consisting of over 40 species. The assemblages contain predominantly Watznaueria barnesae, Reinhardtites elegans, Prediscosphaera cretacea, Eiffellithus eximius, Ahmuellerella octoradiata, Repagulum parvidentatum, small amphizygids(?), zygodiscids, and members of the "BAG" group (Broinsonia-Arkhangelskiella- 
Table 1B. Distribution of Upper Cretaceous calcareous nannofossils, Hole 511.

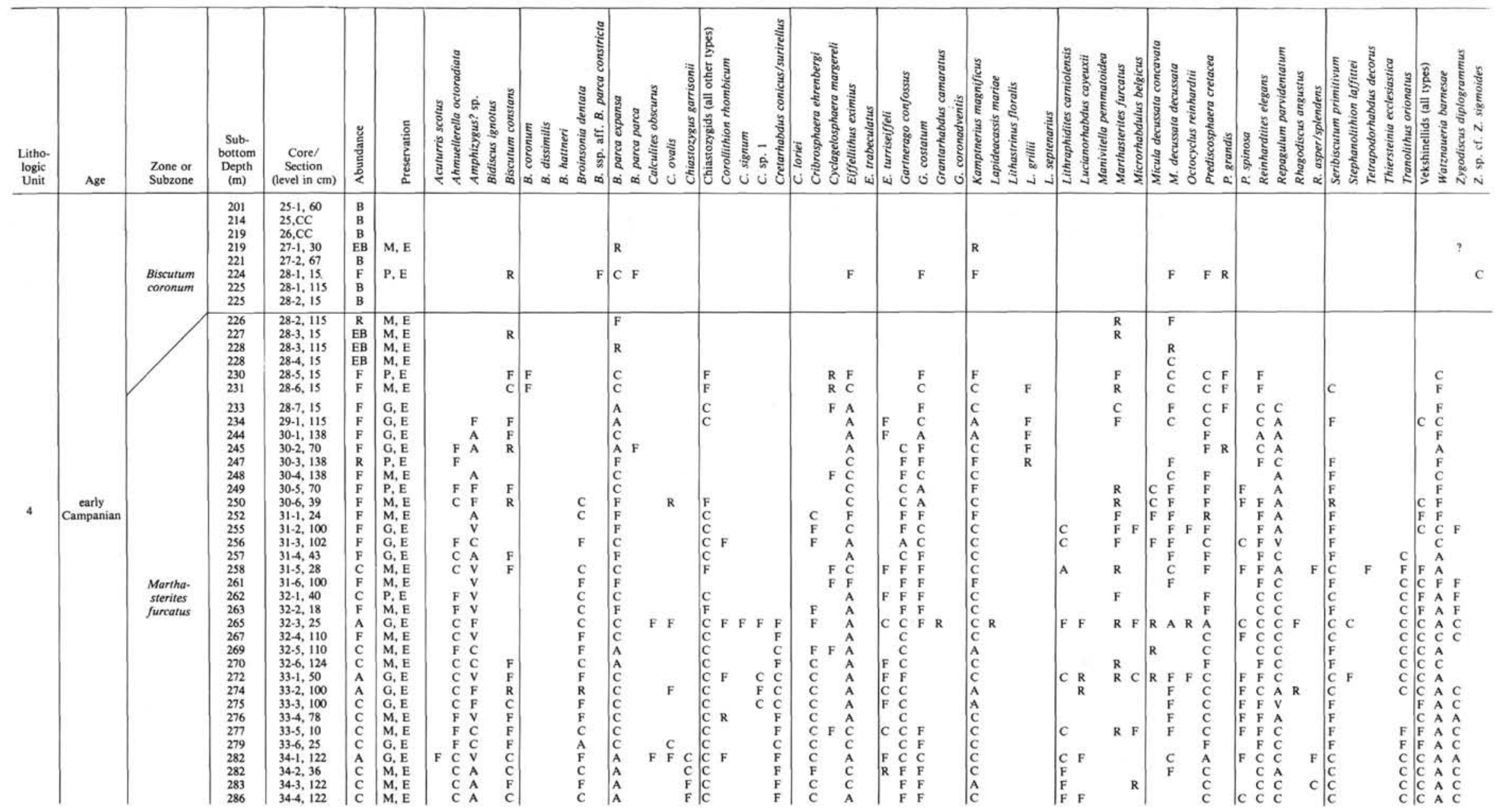




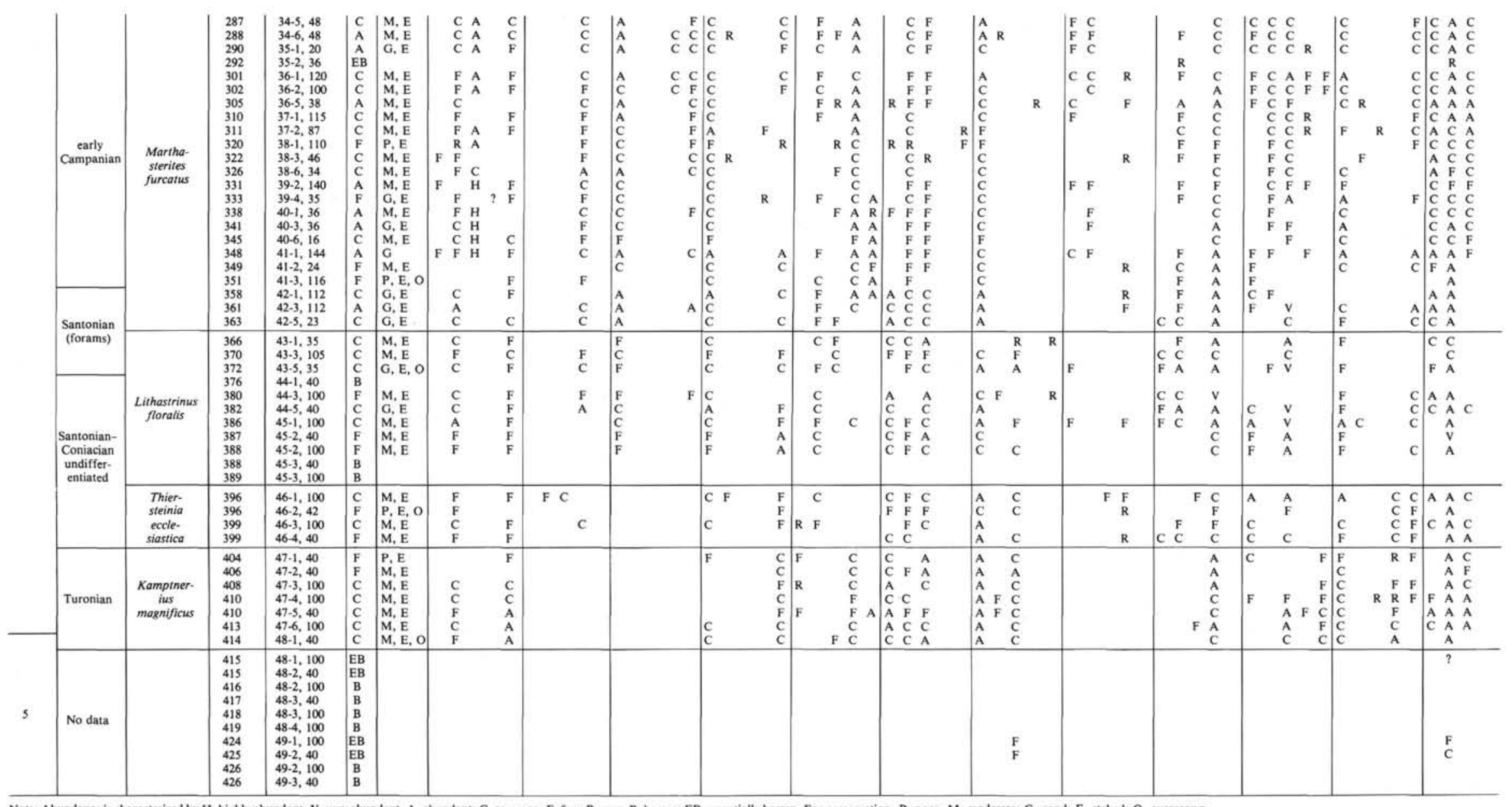


S. W. WISE, JR.

Table 1C. Distribution of Lower Cretaceous and Cenomanian-Neocomian? calcareous nannofossils, Hole 511.

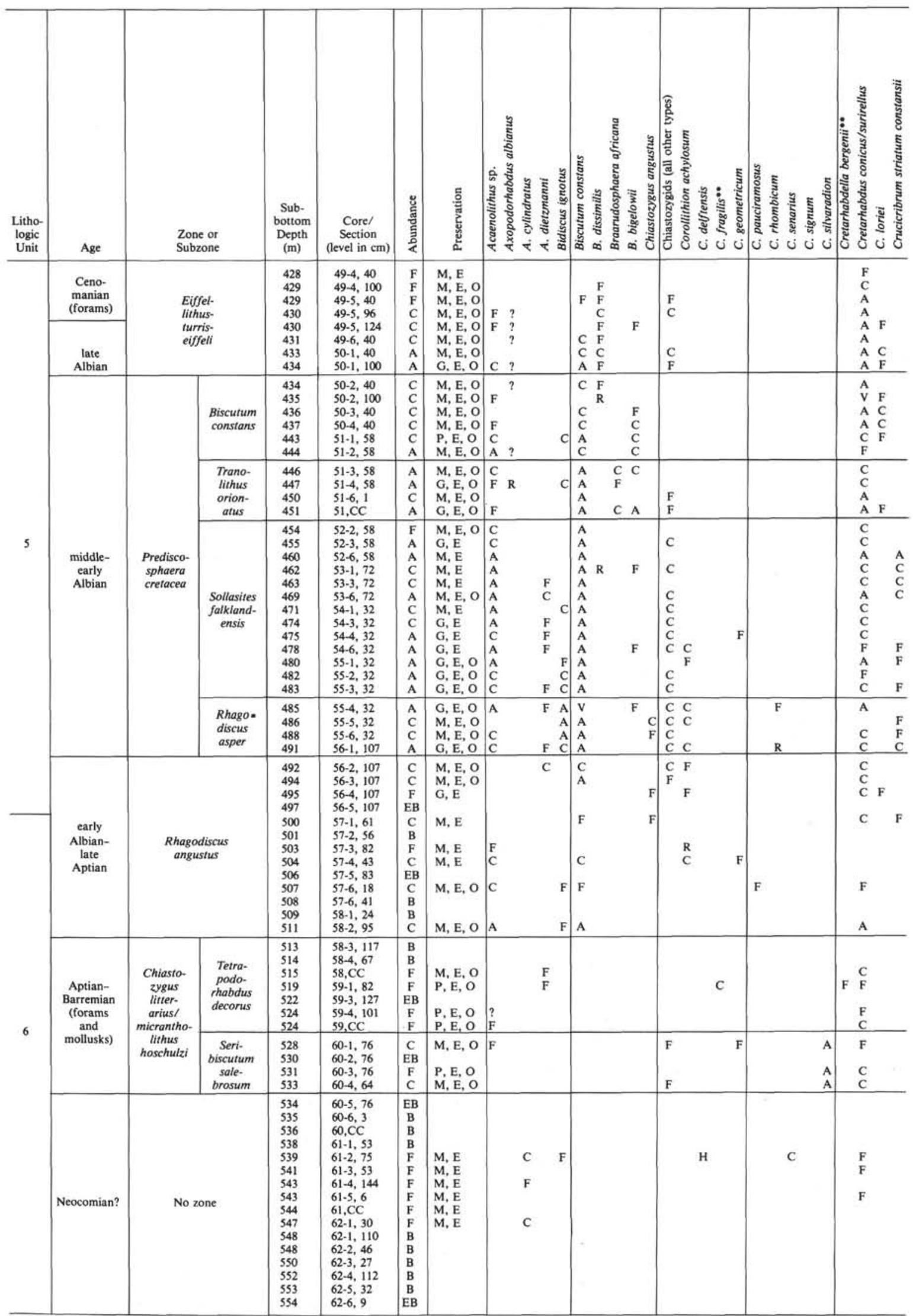

Note: Abundance is characterized by $\mathrm{H}$, highly abundant; V, very abundant; A, abundant; C, common; F, few; R, rare; B, barren; EB, essentially barren; Fr, fragments. For preservation, P, poor; M, moderate; G, good; E, etched; O, overgrown.

* Noted in scanning electron micrographs. 
Table 1C. (Continued).

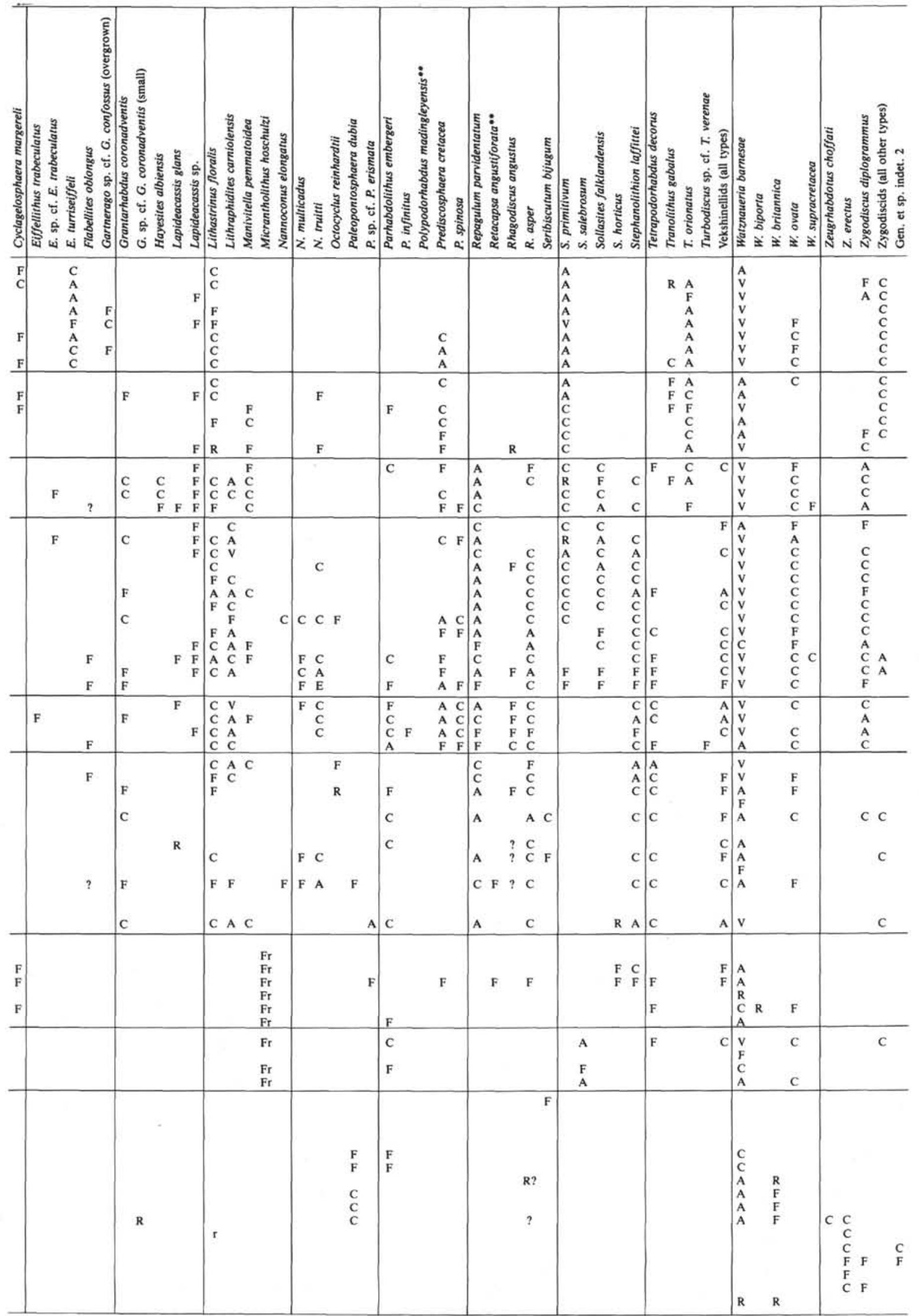


Table 1D. Distribution of Jurassic calcareous nannofossils, Hole 511.

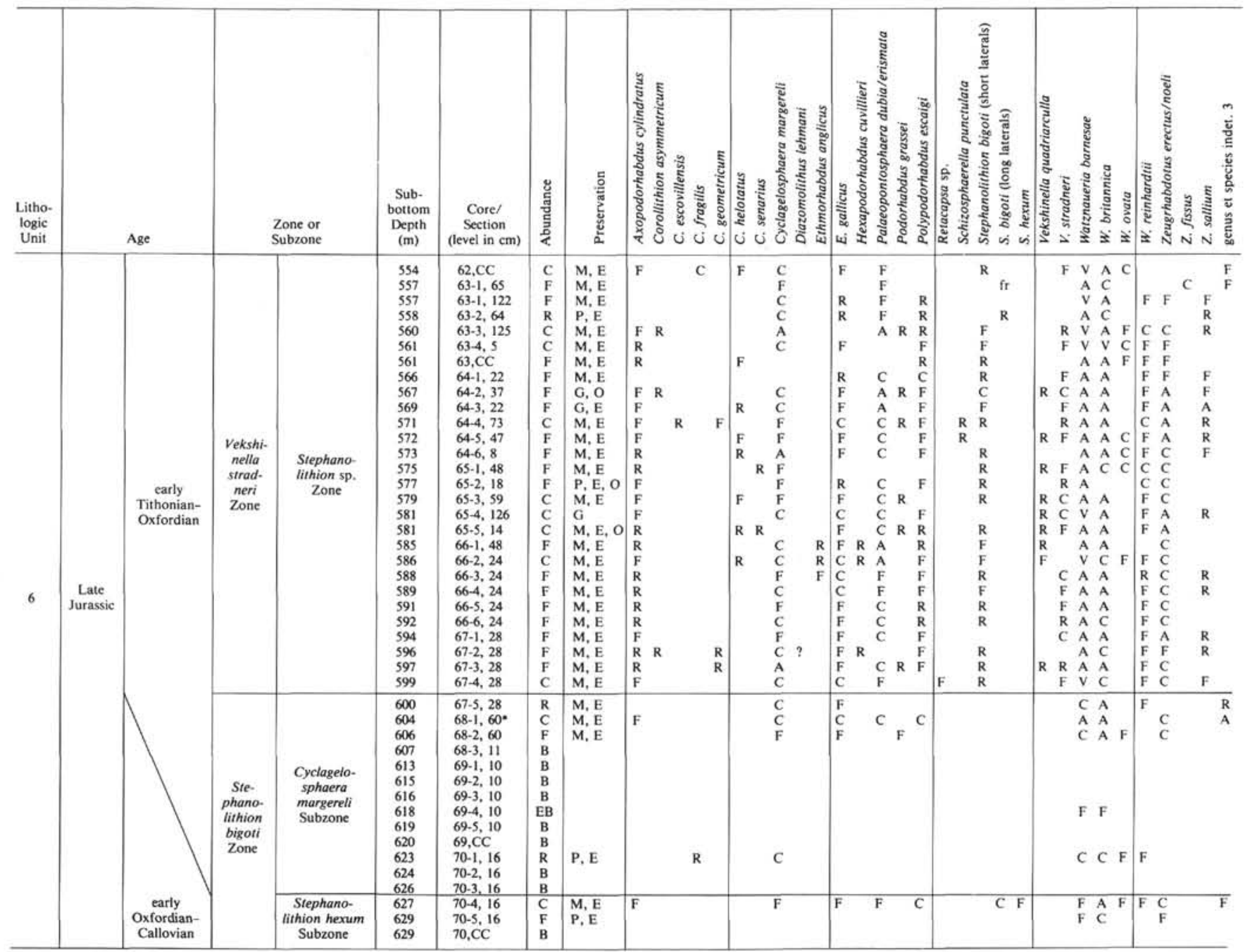

Note: Abundance is characterized by V, very abundant; A, abundant; C, common; F, few; R, rare; B, barren; EB, essentially barren, fr, fragments. For preservation, P, poor; M, moderate; G, good; E, etched; O, overgrown.

- Concentrated by settling.

Gartnerago) plus the closely allied Kamptnerius magnificus. Most prominent among the latter is $B$. parca expansa, which from its distribution in this section can be seen as the progenitor of $B$. parca parca and probably of $B$. parca constricta (see section entitled "Evolution of Broinsonia parca and related forms"). Etching of the assemblages and the near absence of holococcoliths (which are quite common in Lithologic Unit 3) suggests deposition under the influence of a relatively high CCD.

The lower Campanian is so replete with high-latitude nannofloras that its subdivision for local correlation can perhaps best be made using provincial forms. Significant stratigraphic events include the first appearance uphole (FAD) of the abundant Amphizygus (?) sp. (Sample 511-41-2, $24 \mathrm{~cm}$ ). A local event of some importance is the sudden appearance and disappearance of abundant representatives of the long-ranging $E$. trabeculatus (Santonian Sample 511-42-1, $116 \mathrm{~cm}$ and Campanian Sample 511-39-4, $35 \mathrm{~cm}$, respectively). This presumably marks some ecologically important event, perhaps a warming, accompanied by the migration of this species into this area.

The Campanian/Santonian boundary can be located only by planktonic foraminifers and was placed between Cores 41 and 42 by Krasheninnikov and Basov (this volume), who also designated an interval from Section 51143-5 through Core 511-46 as Santonian-Coniacian undifferentiated. The first significant nannofossil datum within those intervals is the extinction of Lithastrinus floralis between Cores 42 and 43 , used here as a zonal marker. The last occurrences of rare $L$. septenarius were also noted at this point.

A major change in the nannofossil assemblages occurs across a barren interval in Section 511-45-3. B. parca expansa apparently disappears at this point and is replaced downhole by Thiersteinia ecclesiastica, a form, newly defined in this report, which ranges down into the Turonian. The stratigraphic relationships within this section plus some ultrastructural similarities between these two forms suggest that $T$. ecclesiastica may have 
given rise to $B$. parca expansa. In any case, the extinction of the former is an easily recognized high-latitude datum which can be used to subdivide the local section. The base of the Coniacian-Santonian is located on the FAD of Marthasterites furcatus and coincides with the boundary chosen on the basis of planktonic foraminifers. Absent at Site 511 below the first $M$. furcatus are Micula decussata and Cribrosphaera ehrenbergi, which generally range further down the column. The FAD of Eiffellithus eximius, which occurs elsewhere in the upper Turonian (Manivit et al., 1977), was marked even higher in the section.

The Turonian is represented at Site 511 by Roth's (1978) Kamptnerius magnificus Zone, which contains the name species in abundance. According to a section restudied by Perch-Nielsen (1979, fig. 1), this zone would begin in the lower to middle Turonian. Krasheninnikov and Basov's evidence (this volume) from planktonic foraminifers suggests that the lower Turonian is present in the short interval between Samples 511-47,CC and $511-48-1,35 \mathrm{~cm}$. This is not contradicted by the nannofossil data since Krasheninnikov and Basov divide the Turonian into only two divisions.

The remainder of Core 511-48 and the first three sections of Core 511-49 are barren of coccoliths. This barren interval represents a period in which the carbonate compensation depth was high in relation to the site of deposition. It coincides with a period of tectonic instability and major paleoceanographic change along the Falkland Plateau following the rifting of South America from Africa (see Barker et al., 1977; Wise et al., 1982).

Calcareous nannofossils are again encountered downhole toward the bottom of Core 49 (Table 1C), where samples down to $511-49-5,96 \mathrm{~cm}$ are dated by planktonic foraminifers as Cenomanian. These and upper Albian samples down to Sample 511-50-1, $100 \mathrm{~cm}$ are assigned to a broad $E$. turriseiffeli Zone, the base of which is well marked in our section. Coccoliths cannot be used to draw the Cenomanian/Albian (i.e., Upper/Lower Cretaceous) boundary at these latitudes because marker species used in tropical zonations are absent. Hayesites albiensis, used to subdivide the E. turriseiffeli Zone at lower latitudes (Manivit et al., 1977), is present but occurs too low in the section to be used.

The late Albian-Cenomanian assemblages differ significantly from those of the Turonian-Campanian and are much closer to those of the early Albian in composition. In addition to the Campanian-Coniacian species just mentioned that were not recorded in the Turonian, a number of other taxa common in the overlying stages are not present in upper Albian-Cenomanian sediments. These include Ahmuellerella octoradiata, K. magnificus, and T. ecclesiastica. The absence of Ahmuellerella octoradiata, if not a diagenetic phenomenon, could indicate that only the lower half of the Cenomanian is present (see Perch-Nielsen, 1979, fig. 2). Planktonic foraminifers (Krasheninnikov and Basov, this volume), however, indicate that the lower Cenomanian is actually missing and only the upper Cenomanian is present.

In addition to the species listed above, the "BAG" group is practically unrepresented in the $E$. turriseiffeli
Zone, except for a few heavily overgrown Gartnerago which are tentatively identified as $G$. confossus. Broinsonias are absent, and their place seems to have been taken by species of Acaenolithus and Crucicribrum. Secondary calcite overgrowths, such as those noted on Gartnerago, are consistently observed from this point downward through the Cretaceous section, an indication that a diagenetic threshold has been reached at this depth because of lithologic and kinetic factors.

The lower to middle Albian Prediscosphaera cretacea Zone is quite expanded at Site $511(57 \mathrm{~m})$, just as it is at Sites 327 and 330. It was subdivided into three subzones by Wise and Wind (1977) and is further subdivided into a total of four subzones here on the basis of a more complete section. One of these subdivisions is the base of the Tranolithus orionatus Subzone which is defined as the FAD of the name species. This datum has been recognized in many parts of the world (Thierstein, 1973; Perch-Nielsen, 1979). It is especially helpful in the present study because it occurs only 5 meters below a local subzone marker, the LAD of Sollasites falklandensis. Thus it helps correlate that locally important and easily recognized datum with the international zonal scale. The fourth subzone boundary is drawn at the FAD of $S$. falklandensis, which occurs about 8 meters above the FAD of $P$. cretacea. About half of the $P$. cretacea Zone, therefore, falls within the $S$. falklandensis Subzone.

The Albian assemblages are dominated by Watznaueria barnesae, accompanied at various levels by common to abundant $T$. orionatus, Biscutum constans, $L$. floralis, Lithraphidites carniolensis, Stephanolithion laffittei, Sollasites falklandensis, Seribiscutum primitivum, Repagulum parvidentatum, Rhagodiscus asper, P. cretacea, E. turriseiffeli, and various species of Acaenolithus, Crucicribrum, Cretarhabdus, and Zygodiscus.

The first consistent occurrence of the distinctive highlatitude species $B$. dissimilis begins within the $B$. constans Subzone, although a rare specimen was noted in Sample 511-53-1, $72 \mathrm{~cm}$ (downhole contamination?). Although consistently present in the middle AlbianCenomanian, $B$. dissimilis is virtually absent in the overlying strata until the upper Campanian-Maestrichtian, where it is again consistent in its occurrence. At present, its absence in the long Santonian-lower Campanian section is something of a mystery. Nevertheless, the first consistent occurrence of this species in the Albian begins just a meter below the first $E$. turriseiffeli, which helps calibrate the former datum for purposes of local correlation.

Another important FAD is that of Seribiscutum primitivum, which coincides with the first Sollasites falklandensis. Both species are few in number at that point in the section.

Nannoconids, particularly Nannoconus truitti, occur only in the $P$. cretacea Zone and in the underlying $R$. angustus Zone. They are few to common in sporadic occurrences. Braarudosphaerids have a similar distribution, which bespeaks the shallow (shelf-break) depths of the plateau at this time (Sliter, 1977) and variations in salinity and/or nutrient supply. Another species which may have interesting ecologic requirements is Corollith- 
ion achylosum, a long-ranging species (upper AptianCampanian; Thierstein, 1973) which appears quite suddenly in the section in Sample 511-54-4, $32 \mathrm{~cm}$ and is common in various samples down to about the base of the Albian. This form was also noted in the lower Albian at Sites 327 and 330 .

The next 20 meters of section is assigned to the $R$. angustus Zone of Thierstein (1973; = his Parhabdolithus angustus Zone) on the basis of the FAD of Lithastrinus floralis. Just how much more of the section below could be included in this zone is not quite clear. At Site 327 this zone was 30 meters thick, but the boundaries were not certain because of the sparse assemblages in the black mudstones. A single specimen of $L$. floralis was noted in Sample 511-61-4, $144 \mathrm{~cm}$, but this is considered a downhole contaminant because of the absence of any other such forms in the intervening 30 meters of section.

The boundary between the well-oxidized nannofossil claystones of Unit 5 and the black mudstones of Unit 6 was cored for the first time in Hole 511, where it is somewhat transitional, with some interfingering of grayish and blackish lithologies in beds across the contact. The lithologic boundary falls just below the Prediscosphaera cretacea Zone near the base of Core 511-56 (see frontispiece). The Albian/Aptian boundary can be located only on the basis of planktonic foraminifers and has been placed between Cores 57 and 58 (FAD of Ticinella roberti, see Krasheninnikov and Basov, this volume), some 17 meters below the base of the $P$. cretacea Zone. This is in good agreement with the placement of the lower boundary of the Prediscosphaera cretacea Zone within the lower Albian by Thierstein (1973) rather than at the Albian/Aptian boundary as indicated by Roth (1978).

The occurrence of coccoliths in the black mudstones of the Rhagodiscus angustus Zone is sporadic. In the light microscope, many samples are recorded as barren. In the scanning electron microscope, however, there appear pods of coccoliths which were probably deposited as fecal pellets and which contain diverse and often reasonably well-preserved floras. More information on these assemblages and on nannofossil carbonate cycles in these black mudstones is given in Parker et al. (this volume). One interesting form noted in the SEM studies was Seribiscutum bijugum (Pl. 32, Figs. 1-4) which was initially described from Site 330 and which is the presumed progenitor of S. primitivum (Wise and Wind, 1977).

Planktonic foraminifers, palynomorphs, and molluscs date the interval from 513 to 533 meters as Barremian to Aptian. Section 511-58-4 and Sample 511-58, $\mathrm{CC}$ are barren of coccoliths, but the assemblages below, down to $511-60-4,64 \mathrm{~cm}$ are distinctive in that they contain a flood of Micrantholithus hoschulzi fragments which appear as small wedge-shaped fragments of calcite. A thin nanno chalk correlative to this unit has been discussed in detail by Wise and Wind (1977; see also frontispiece to Barker, Dalziel, et al., 1977). Sissingh (1977) gives the LAD of $M$. hoschulzi as mid-Aptian. Core 60 from this interval contains an easily recognized subassemblage dominated by $S$. salebrosum and Corollithion silvaradion (Plates 29-31), the latter strongly affected by diagenesis. Taylor (1982) gives the range of $S$. salebrosum in the Boreal Realm as Ryazanian to lower Barremian. This LAD is somewhat higher than that plotted by Sissingh (1977) in the Hauterivian. This chapter is the first report of that species in the Southern Hemisphere, and therefore its range here has not been ascertained. A second bothersome question that must be considered concerns the extent to which diagenetic factors which altered the corollithions in this interval may have affected the species which is here referred to as $S$. salebrosum. Nevertheless, the association of $S$. salebrosum and $C$. silvaradion in this interval could potentially be useful for local correlation.

\section{Neocomian?}

The next nannoliferous interval encountered in this portion of the black mudstones is separated from the above assemblage by a barren interval and runs from Sections 511-61-2 to 511-62-1. The nannofacies and assemblages in this sequence are most peculiar. SEM studies of Sample 511-61-2, $75 \mathrm{~cm}$ reveal pods of coccoliths which consist nearly entirely of Corollithion senarius and C. delftensis (Pl. 33, Figs. 3-4), suggesting either highly restricted floras in the surface waters or else highly selective appetites among the surface-grazing zooplankton. Such "nannofacies" have been described previously by Noël (1973), Noël and Manivit (1978), and to some extent by Wise and Wind (1977).

The second peculiarity of these sediments is a biostratigraphic one. Palynomorphs (Kotova, this volume) and foraminifers (Krasheninnikov and Basov; Basov and Krasheninnikov, both this volume) date these rocks as Cretaceous. Kotova (pers. comm. to Krasheninnikov, 1981) suggested an earliest Cretaceous age. Rare planktonic hedbergellid foraminifers, if not downhole contaminants, suggest a Barremian or younger age (Krasheninnikov and Basov, this volume). Age-diagnostic molluscs are not present in this interval, which consists of fine mudstones (Jeletzky, this volume). Dinoflagellates (Goodman and Millioud, 1982, pers. comm.) suggest a Jurassic age.

Coccoliths are few in this interval, but have been observed in both the SEM and light microscope. Among those present, Cretarhabdus conicus (PI. 32, Figs. 7-8) is generally considered a Cretaceous form, although Wind (1978) suspected that it ranged down into the Jurassic. Corollithion delftensis has been reported from both the Cretaceous and Jurassic as well as Watznaueria barnesae, $W$. britannica, Zeugrhabdotus erectus, and Palaeopontosphaera dubia. The specimens identified as Axopodorhabdus cylindratus, Z. choffati, and C. senarius, however, have been reported previously only from the Jurassic. An unidentified species labeled here "Genus et Species indet. 3" has been found only in this interval and in the Jurassic below. In addition, $W$. britannica, Z. erectus, and P. dubia are far more prevalent in the Jurassic than in the Cretaceous. Somewhat peculiar is our failure so far to detect Parhabdolithus embergeri in this assemblage, an index species common in 
superjacent units and one which ranges from the Cretaceous down into the uppermost Jurassic in the Boreal and Tethyan provinces.

In short, the nannofossil assemblage described above has aspects of both Cretaceous and Jurassic nannofloras. A similar assemblage was noted previously in nearby Core 330-4, which also contained the unequivocally Upper Jurassic form Stephanolithion bigoti (short laterals) in Section 330-4-2 and Sample 330-4,CC (Wise and Wind, 1977, table 6C), a finding confirmed by Medd (in press). This same core was dated as Cretaceous (late Neocomian to Aptian) on the basis of palynomorphs, however, by Harris (1977), who did note Jurassic species which he considered reworked into the Cretaceous. Thus the same disparity between coccolith and palynomorph ages for this part of the section has resulted from studies of Core 330-4 and Core 511-61, which were recovered at sites only $10 \mathrm{~km}$ apart.

All of the above would not be a problem if there was a distinct lithologic boundary between the Jurassic and Cretaceous at Sites 511 and 330. Unfortunately no such lithologic boundary has been discovered at either site, despite the apparent existence of a 20-m.y. hiatus within the section at both sites. Such a hiatus is suggested by the fact that no unequivocally Berriasian, Valanginian, or Hauterivian coccoliths have been noted anywhere in the section. Conspicuously absent are index species such as Speetonia colligata Black, 1971, and Cruciellipsis cuvillieri (Manivit) Thierstein, 1971, which are common in the Hauterivian of England (Boreal) and which should be present in our section if the appropriate strata were present. Also absent are Calcicalathina oblongata (Worsley) Thierstein, 1971, Lithraphidites bollii (Thierstein) Thierstein, 1973, Diadorhombus rectus Worsley, 1971, and a wide variety of nannoconids, including the longranging Nannoconus colomii (de Lapparent) Kamptner. The absence of the first three species could conceivably be a result of ecological exclusion since they have only been described from the lower latitudes.

As stated earlier, there is no distinct lithologic boundary to mark a hiatus at or near the Jurassic/Cretaceous boundary. Instead, anoxic black mudstones occur throughout both the Upper Jurassic and Lower Cretaceous (until the Albian) of Sites 330 and 511. Any hiatus present, therefore, must be detected paleontologically. The conclusion at which Wise and Wind (1977) finally arrived was that the interval in doubt in their section (Core 330-4) was probably Cretaceous (based on the palynomorphs) and that the coccoliths therein were reworked from the underlying Jurassic (sampled in Cores $330-5$ to 330-14). Upon examination of the continuously cored section from Hole 511, however, this hypothesis of reworking seems somewhat less likely because (1) coccoliths in Core 511-61 are reasonably well preserved, and (2) coccoliths are hardly more common in the underlying Jurassic than in Cores 511-61 and 511-62. Assuming some loss in transport, it would seem difficult to achieve any appreciable concentration of Jurassic coccoliths in younger strata through reworking. In addition, delicate forms such as Corollithion appear, well preserved and in profusion, in selected samples from
Core 511-61 (Plate 33, Figs. 3-4) and certainly could not have been reworked individually.

A second possibility is that the necessarily long-range correlation of the pollen and spores could be somewhat imprecise, since the land sections of South Africa used as reference sections are distant and have not been studied in great detail (see Basov et al., this volume, for more discussion). The difference in uppermost Jurassic and lowermost Cretaceous palynomorph assemblages may be difficult to discern at this point. The section, then, could conceivably be dated as Jurassic. If this were the case, then the hedbergellid foraminifers in Cores 511-61 and 511-62 would have to be regarded as downhole contaminants.

The last possibility is that coccoliths in the section in question in Hole 511 constitute a natural Cretaceous rather than a Jurassic assemblage and that the forms with Jurassic affinities are simply long-ranging species that transcend the boundary. Because independent evidence from other localities has not yet been discovered to confirm Wind's (1978) evidence that Cretarhabdus conicus does in fact range down into the Upper Jurassic, I at present tentatively assign the section at Site 511 to the Cretaceous, although reworking cannot yet be ruled out. The interval at both this site and at Site $\mathbf{3 3 0}$ needs further study before a conclusion can be drawn. Since the differences of opinion on this question could not be resolved among all the various paleontological disciplines during the time allotted for this initial investigation, the interval is labeled here as "Neocomian?" on the range chart (Table 1C).

\section{Jurassic (Table 1D)}

Beneath the nearly barren interval sampled from Sections 511-62-2 to 511-62-6, coccoliths are again encountered in some numbers in Sample 511-62,CC. Nannofossils are thence few to common but persistently present downsection to Section 2 of Core 511-68. The assemblages within this interval are Jurassic, as is evidenced by the presence of Stephanolithion bigoti (longand short-spined forms), Ethmorhabdus gallicus, E. anglicus, Corollithion minutus, C. escovillensis, C. helotatus, Hexapodorhabdus cuvillieri, and Watznaueria reinhardtii. Assemblages down to Sample 511-67-3, 28 $\mathrm{cm}$ contain Vekshinella stradneri and can be assigned to the zone of that name as delineated by Barnard and Hay (1974); in England, this zone ranges from the middle Oxfordian into the Kimmeridgian.

Included in this interval are a few specimens of Retacapsa which are similar to those which Wise and Wind (1977) identify as $R$. angustiforata. Their presence indicates that this genus and, in particular, this species, cannot be used to define the base of the Cretaceous as has been done in some recent publications (e.g., Roth, 1978; Taylor, 1982). Another form which transcends the Cretaceous/Jurassic boundary is Watznaueria britannica, which achieves dominance over $W$. barnesae below the FAD of $V$. stradneri. A form that may transcend the boundary, depending on one's taxonomic concept, is the species labeled in this study Polypodorhab- 
dus escaigi, some specimens of which exhibit a double rim cycle (Pl. 33, Fig. 5; see "Systematic Paleontology" for comments on the taxonomy of this species).

$S$. bigoti, in the interval from Sample 511-62,CC to Core 511-68, consistently exhibits short lateral spines except for rare long-spined specimens and fragments thereof toward the top of the section (Pl. 34, Fig. 2). Short-spined forms were present in DSDP Cores 330-5, 6 , and 7 , which comprise the top of the Jurassic section in the nearby Leg 36 hole. This form appears to be useful for local correlation and for correlation with Boreal assemblages described from the type Volgian Stage of Russia by Medd (in press). Medd (pers. comm., 1981) intends to designate this form as a new species, based on specimens from the Volga Basin. Those specimens are quite narrow in width, range in size from 2 to $4 \mu \mathrm{m}$ long, and have very short lateral spines. Specimens from the Falkland plateau are generally larger (4 to $6 \mu \mathrm{m}$ ), have more pronounced lateral spines (Pl. 34, Figs. 3-4; see also Wise and Wind [1977], pl. 79, figs. 1-3; plate 89, figs. 1-3), and are more oval than the specimens described by Medd (in press). Medd (in press) considers the Falkland morphotypes to be species equivalents of the Volgian specimens. They could also perhaps be viewed as forms transitional between long-spined specimens of S. bigoti (Plate 34, Fig. 1) and the small, narrow Volgian specimens. Nevertheless, the short-spined forms from the Falkland Plateau are easily distinguished from the long-spined morphotype. At Site 511, the short-spined form is overwhelmingly dominant above its FAD in Section 511-67-4 and seems to provide a stratigraphically useful datum for local correlation, also perhaps for correlation with the Volgian section described by Medd (in press).

The continuously cored section from $511-62, \mathrm{CC}$ to the barren interval beginning at $511-68-3,11 \mathrm{~cm}$ is closely equivalent to the section spot-cored at Site 330 from Cores $330-5$ to $330-7$. The precise age of this interval, measured in stage terminology, has always been a subject of some uncertainty. Molluscan data (Jones and Plafker, 1977; Jeletzky, this volume) call for a Kimmeridgian to early Tithonian age. Palynologists differ somewhat between Oxfordian-Kimmeridgian (Harris, 1977) and Kimmeridgian-early Tithonian (Kotova, this volume) for the sections at Sites 330 and 511. Goodman and Millioud (pers. comm., 1982) date the dinoflagellates from Cores 511-61-67 as early Kimmeridgian to late Oxfordian. The deepest sample they examined, $511-70-1,50 \mathrm{~cm}$, is dated as early Oxfordian to late Callovian in age.

In regard to the age of the Jurassic section at Site 330, Wise and Wind (1977) noted the presence of Vekshinella stradneri and assigned the interval to Barnard and Hay's (1974) V. stradneri Zone, based in part on the presence of $S$. bigoti (long- and short-spined forms). From the literature available at that time, they further noted (p. 287) that:

Although Medd (1971) and Rood and Barnard (1972) concluded that $S$. bigoti is probably confined to Callovian and Oxfordian strata of England and Northern France, the absence of coccoliths in the lowermost Kimmeridgian of Northern Europe leaves open the possibility that this zone may extend as high as lower Kimmeridgian in other areas.

That possibility indeed turned out to be the case, as documented by Wind (1978) and Hamilton (1982). Medd (in press) confirms that forms of $S$. bigoti with long lateral spines range into the lower Kimmeridgian as high as the ammonite Aulacostephanus autissiodorensis Zone. The range of forms of $S$. bigoti with short lateral spines in his Russian section extends somewhat higher into the middle Volgian (which is equivalent to the top of the Kimmeridgian of England).

Thus it seems from these observations that the interval from DSDP Hole 511 beginning at 511-62,CC and extending down to Section 511-67-4 at a minimum is equivalent to the English Kimmeridgian and approximately the lower half of the Russian Volgian (including possibly some portion of the Russian Kimmeridgian). This would be equivalent to the lower Tithonian (including possibly the lowermost portion of the upper Tithonian) of the Tethyan Realm. This correlation does not conflict with the opinion of mollusk specialists who have examined the Falkland Plateau material (Jones and Plafker, 1977; Jeletzky, this volume). The interval can be assigned to Barnard and Hay's (1974) V. stradneri Zone or to a zone based on the predominance of short-spined $S$. bigoti over any other variety present. Since Medd plans to name the short-spined form as a new species, the zone is simply noted as the Stephanolithion sp. Zone on the range chart (Table 1D).

Little can be said for most of the section between 51167-5 and 511-70-3, since most of the samples were barren of coccoliths. Sample 511-68-1, $60 \mathrm{~cm}$ was concentrated by settling techniques but failed to yield stagediagnostic species. This coccolith-poor interval falls conveniently within Roth, et al.'s (in press) Cyclagelosphaera margereli Interval (= gap) Subzone.

Sample 511-70-4, $16 \mathrm{~cm}$ did yield a distinctly different nannoflora containing common $S$. bigoti with long lateral spines (Pl. 34, Fig. 1) and few $S$. hexum (Pl. 33, Figs. 6-8). Interestingly, the latter have distinctly shorter spines than the holotype described by Rood and Barnard (1972) and other specimens of this species figured subsequently from England and Northern Europe. Perhaps the short spines are an ecological variation prevalent in higher latitudes. Rood and Barnard (1972, p. 331) state that in France $S$. hexum first appears in the ammonite Clydoniceras discus Zone (uppermost Bathonian) and ranges nearly to the top of the Callovian. Hamilton (1982, p. 25) concludes that "the full stratigraphic extent of $S$. hexum is from the base of the Callovian to the ammonite Peltoceras athleta Zone in the upper Callovian"' in the combined French and English sections. Medd (1979; in press), however, finds that in England the species ranges as high as the lower Oxfordian ammonite Cardoceras cordatum Zone, although its highest common occurrence is in the Callovian (top of the ammonite Eurymonoceras coronatum Zone). It seems, therefore, that the assemblage encountered in Sample 511-70-5, $16 \mathrm{~cm}$ could be either Callovian or early Oxfordian in age, and that Roth, et al.'s (in press) $S$. hexum Subzone could be applied in this instance. 


\section{Site 512 (Table 2)}

Site $512\left(49^{\circ} 52.194^{\prime} \mathrm{S} ; 40^{\circ} 50.713 \mathrm{~W}\right.$; water depth, $1846 \mathrm{~m}$ ) situated on the northeastern corner of the Maurice Ewing Bank, was hydraulic piston cored continuously to a sub-bottom depth of $77.9 \mathrm{~m}$ and rotary drilled in a second hole to a sub-bottom depth of $89.3 \mathrm{~m}$. A surficial $0.93 \mathrm{~m}$ upper Pleistocene to lower Pliocene glacial marine sequence (Lithologic Unit 1) is separated by a disconformity from 19 meters of a mixed calcareous nannofossil-diatomaceous ooze of middle to late Miocene age (Lithologic Sub-units 2A and 2B). Beneath that is 69 meters of greenish gray siliceous nannofossil ooze of middle Eocene age (Lithologic Subunit 2C).
The top of the section at Site 512 contained a late Quaternary coccolith assemblage belonging to the Emiliania huxleyi Zone. The next 20 meters yielded common to abundant, moderately to well-preserved, middle-late Miocene coccoliths of very limited diversity. The half dozen or so taxa are dominated by reticulofenestrids. At the top of the Miocene section these were primarily Reticulofenestra perplexa (=Dictyococcites antarcticus $\mathrm{Haq}$ ). These gave way in the middle of the section (Sections 512-2-3 to 512-4-3) to $R$. pseudoumbilica gelida, which strongly dominates the assemblage. The fluctuations between these two reticulofenestrids may represent climatic shifts, with $R$. perplexa representing the cooler water end member. Such fluctuations in the Miocene

Table 2. Distribution of middle Eocene, Miocene, and Quaternary calcareous nannofossils, Site 512.

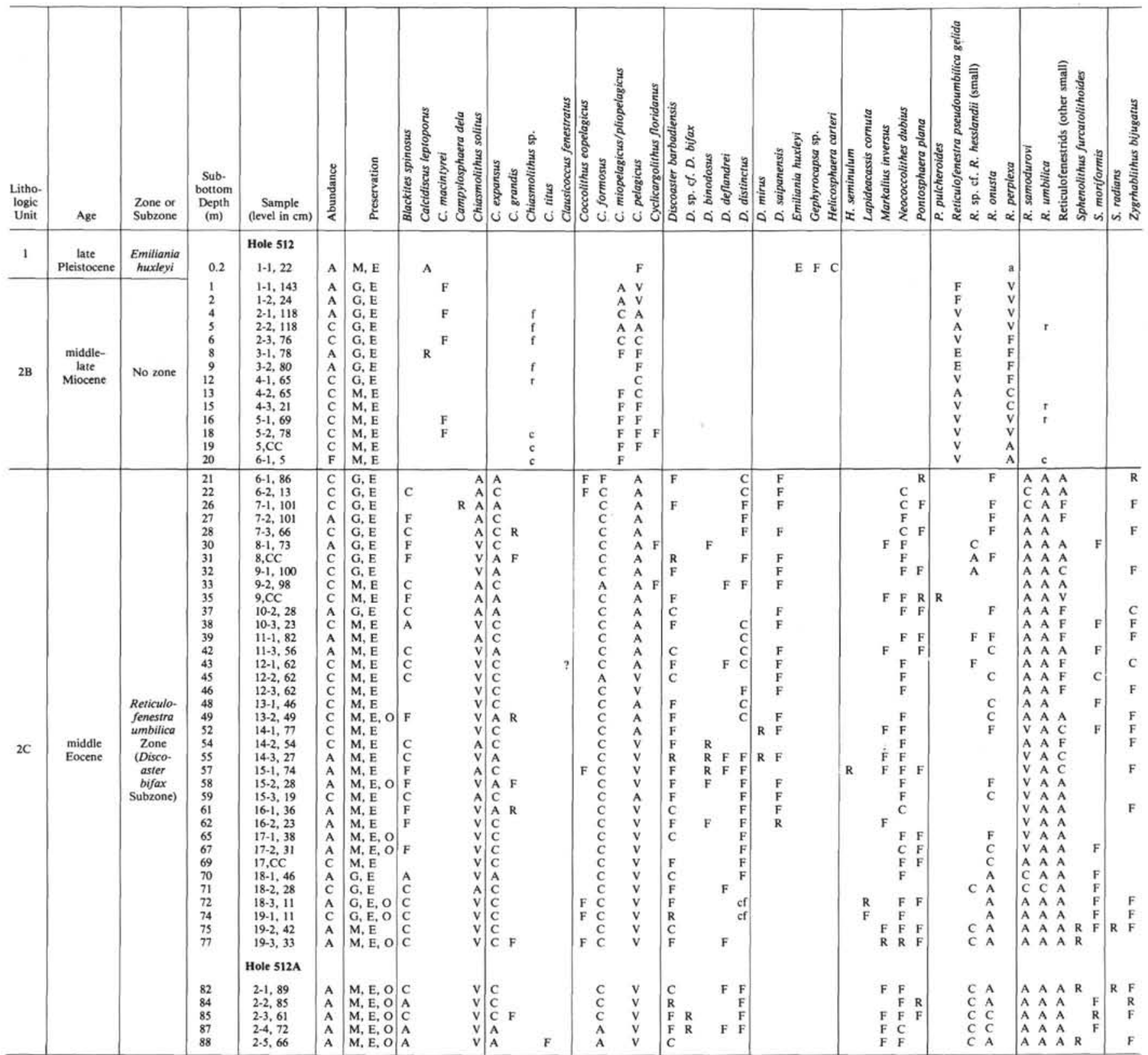

Note: Abundance is characterized by E, extremely abundant; V, very abundant; A, abundant; C, common; F, few; R, rare. For preservation, P, poor; M, moderate; G, good; E, etched; O, overgrown. Lower-case letters indicate material considered to be reworked 
have been mapped on a grand scale throughout the Atlantic Basin by Haq (1980). The third most important taxon in the assemblage is Coccolithus pelagicus. A few reworked Paleogene forms, particularly rims of Chiasmolithus, are present. This same assemblage was cored in the long section at DSDP Site 329 and in many other Miocene localities on the Maurice Ewing Bank mapped by Ciesielski and Wise (1977, fig. 4).

Unfortunately for stratigraphic purposes, the coccolith species mentioned above are long-ranging and the assemblage is indistinguishable in the high southern latitudes from the middle Miocene to some point in the Pliocene. Correlation of the section at this site with lower latitudes is dependent on diatom and radiolarian biostratigraphies.

In the remainder of the section, coccoliths are common to abundant and belong to Bukry's (1973a) Discoaster bifax Subzone of his middle Eocene $R$. umbilica Zone. This zone is delimited by the FAD of $R$. umbilica and the LAD of $C$. solitus. Both of these marker species are abundant or very abundant in the section at Site 512 .

As opposed to the overlying Miocene section, diversity in the Eocene is reasonably high for this latitude, with close to 30 species recorded (Table 2). The cool-water chiasmoliths, reticulofenestrids, and the species $\mathrm{Coc}$ colithus pelagicus are strongly dominant. The warmer water discoasters and sphenoliths maintain a marginal existence. Chiasmolithus solitus is the dominant member of that genus. $C$. expansus is well represented but $C$. titus is extremely rare. C. grandis occurs sporadically. Because of less than optimal preservation, the smaller reticulofenestrids in this section have not been worked out in detail. In the intermediate size range, $R$. onusta could be readily distinguished in the light microscope. It increased in number downsection.

A variety of discoasters were noted in the section. Discoaster saipanensis appeared in Core 512-16 and continued sporadically upsection. Eight-rayed forms which could be considered transitional between $D$. barbadiensis and D. saipanensis were present throughout the section, but were counted with the former species. Rare specimens which can probably be attributed to $D$. bifax were noted in Core 512A-2 at the base of the section.

A distinctive but rarely occurring marker species is Sphenolithus furcatolithoides (Pl. 8, Figs. 8-9), which occurred in the basal cores of Holes 512 and 512A along with rare $S$. radians. Bukry (1973a) notes that the extinction of S. furcatolithoides occurs within the Discoaster bifax Subzone. The LAD of this species, although rare, may serve as a useful datum if it is not ecologically controlled.

Judged from these observations, the sediment accumulation rate during this rather brief interval of the middle Eocene was quite high on the Falkland Plateau. Bukry (1973b) estimates the duration of the D. bifax Subzone to be about one million years; thus the sediment accumulation rate for this section would be in excess of a minimum of about $70 \mathrm{~m} / \mathrm{m}$.y. The middle Eocene assemblage is easily distinguished from that of the upper Eocene encountered in Hole 511 by marked changes among the reticulofenestrids and chiasmoliths plus the presence of rather different floral elements such as
Neococcolithes dubius as opposed to Isthmolithus recurvus. This middle Eocene assemblage has been sampled elsewhere on the Maurice Ewing Bank in piston cores described by Wise and Mostajo (this volume).

\section{Site 513 (Table 3)}

Located on the lower Mid-Atlantic Ridge flank, east of the Argentine Basin, Hole $513\left(47^{\circ} 34.99^{\prime} \mathrm{S} ; 24^{\circ}\right.$ $38.40^{\prime} \mathrm{W}$; water depth $4,373 \mathrm{~m}$ ) was drilled and continuously cored to 140 meters sub-bottom. A second hole, $513 \mathrm{~A}$, was washed to 70 meters, thence rotary cored continuously until it terminated in basement basalt at 587 meters sub-bottom.

Calcareous nannofossils were present only in Lithologic Units 2 and 3. Lithologic Unit 1 consisted of 180 meters of muddy diatomaceous ooze of Miocene to Pleistocene age. Unit 2 consisted of 53.9 meters of diatomaceous nannofossil ooze ranging from late Oligocene to possibly early Miocene in age. Unit 3 (145.5 m thick) is a light gray and white nannofossil ooze which contains some indurated chalk layers and chert at the base of the sequence. Unit 4 was 6 meters of finegrained basalt.

Calcareous nannofossils were absent in the top 180 meters of the section as a result of down-flank subsidence of the site below the carbonate compensation level. They are present in Lithologic Units 2 and 3, however, which represent most of the Oligocene. Preservation is generally moderate to good, although secondary calcite overgrowths become more troublesome downsection. Six zones are recognized in this interval, the basal part of which overlaps in time the long Oligocene section cored at Site 511. Whether or not one would consider the top of the nannoliferous section to be Miocene depends on one's species concept of Cyclicargolithus abisectus and the correlation of the zone of that name with the low-latitude planktonic foraminiferal zonation. I include all forms that are $9 \mu \mathrm{m}$ or longer in my concept of $C$. abisectus (based on measurements of the holotype). I prefer Bukry's (1973a) placement of the C. $a b$ isectus zone within the Oligocene and Bolli and Krasheninnikov's (1977) placement of the corresponding Globigerina woodi connecta Zone within the Oligocene (see Basov et al., this volume, for a discussion of alternate correlations). On that basis, there would probably be no Miocene coccolith assemblage represented at this site.

The assemblage of the C. abisectus Zone (Sections 513A-13-2 to 513A-14-2) is of low diversity, as would be expected at this high latitude $\left(48^{\circ} \mathrm{S}\right)$. Discoasters are generally few and diagnostic sphenoliths are absent. Instead the assemblage is dominated by the Coccolithus pelagicus plexus along with abundant Cyclicargolithus floridanus.

The LAD of Reticulofenestra bisecta bisecta is sharp and provides an easily distinguished boundary for the next zone downhole. The remainder of the assemblage is unchanged except that reticulofenestrids, including $R$. daviesii, appear in greater numbers beginning in Sample 513A-15, CC.

A barren interval at the base of Core 513A-15 separates the $R$. bisecta Zone from the underlying Chiasmolithus altus Zone, the top of which is marked by the 
Table 3. Distribution of Oligocene calcareous nannofossils, Hole 513A.

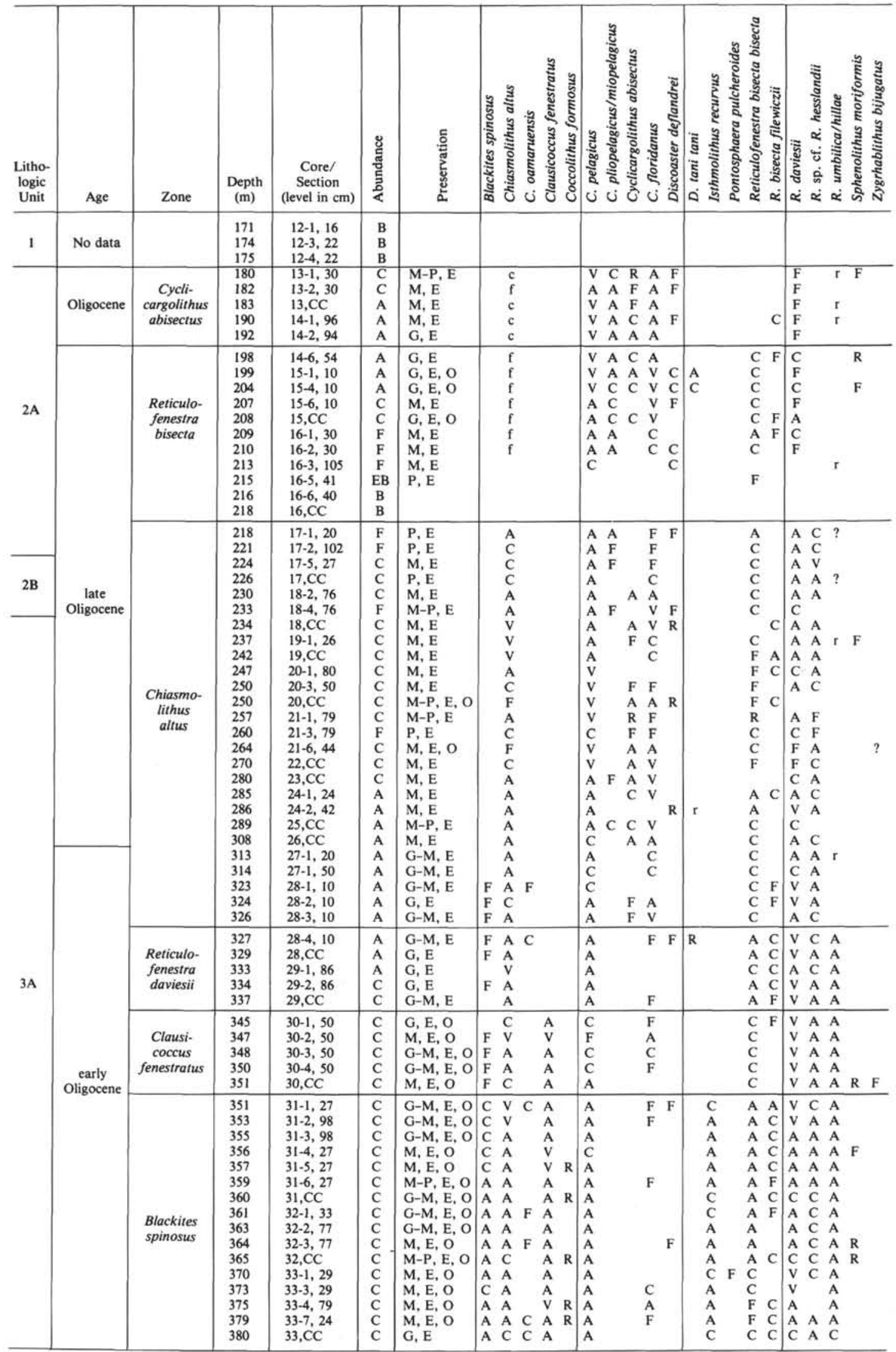

Note: Abundance is characterized by V, very abundant; A, abundant; C, common; F, few; R, rare; B, barren, EB, essentially barren. For preservation, P, poor; M, moderate; G, good; E, etched; O, overgrown. Lower-case letters indicate material considered to be reworked. 
last common occurrence of that species. Specimens of C. altus above this level are generally few in number, poorly preserved, and are considered reworked. This reworking does make the selection of the top boundary of this zone somewhat subjective.

Except for the addition of the nominate species, the assemblage of the $C$. altus Zone is little changed from the $R$. bisecta Zone except for about half a dozen major fluctuations in dominance between members of the genera Cyclicargolithus and Reticulofenestra. Based on the work of Haq (1980), these fluctuations would indicate climatic shifts, with Cyclicargolithus representing the warmer water end member. The last Blackites spinosus uphole is noted near the base of the zone.

The boundary between the Chiasmolithus altus Zone and the underlying $R$. daviesii Zone is sharp, based on the LAD of $R$. umbilica. This boundary also happens to coincide with the FAD of Cyclicargolithus abisectus, which is probably climatically controlled, since $C$. floridanus is very common in the same sample but not in those immediately below. Indeed, below this boundary Cyclicargolithus becomes a minor constituent of the assemblages, indicating that the early Oligocene may have been measurably colder than the later Oligocene in this region. This is also indicated by the distribution of discoasters in the section. The FAD of $C$. abisectus is also noteworthy because it occurs somewhat lower here than the level at which it has been recorded in lower latitudes (Bukry, 1973a). This may indicate that its range is somewhat extended in the higher latitudes.

The assemblage of the $R$. daviesii Zone is dominated by the nominate species. At this level in the section the reticulofenestrids are quite diverse and abundant.

The LAD of Clausicoccus fenestratus provides another sharp and easily recognized zonal boundary in this section, although it must be recognized in an overgrown state. All of the specimens here have suffered heavy secondary overgrowths in the central area which have obliterated the perforation pattern. The species is distinguished from small specimens of Coccolithus pelagicus by the fact that its central area in proportion to the shield margin is considerably larger than that of $C$. pelagicus.

The last zone in the sequence, the Blackites spinosus Zone ( $=B$. rectus Zone of Edwards, 1971), is also well marked by the LAD of Isthmolithus recurvus. Again the zonal marker happens to be highly susceptible to secondary calcite overgrowth and must be distinguished in a highly overgrown state ( $\mathrm{Pl}$. 4, Figs. 1-2). The remainder of the assemblage is little changed from the assemblage above, except that $B$. spinosus becomes common to abundant. A locally important marker may be C. formosus, which has its LAD in this area within the B. spinosus Zone, just as it did at Site 511. Unfortunately it is rare and sporadic in its occurrence.

\section{Site 514}

Site $514\left(46^{\circ} 02.77^{\prime} \mathrm{S} ; 26^{\circ} 51.30^{\prime} \mathrm{W}\right.$; water depth 4318 $\mathrm{m}$ ) is located on the lower west flank of the Mid-Atlantic Ridge on the east side of the Argentine Basin. It lies about $150 \mathrm{~km}$ north of Site 513 and about $250 \mathrm{~km}$ north of the present-day position of the Antarctic Polar Front. The primary objective of drilling at the site was to detect climatically induced migrations of the Polar Front during the glacial epochs. Pliocene-Quaternary gray to greenish gray diatomaceous oozes were hydraulic piston cored to a depth of 150.8 meters.

Coccoliths were present in only a few of the cores examined from the Plio-Pleistocene section recovered at this site. They are sparse except in a few intervals near the bottom of the hole. Preservation was poor to moderate, an indication of deposition close to the CCD. Forms preserved were primarily dissolution-resistant species such as Coccolithus pelagicus, C. pliopelagicus, and Calcidiscus leptoporus. Such forms were found at various intervals in Cores 6, 7, 15, 19, 22, 28, and 31-33. All other cores were barren except for occasional specimens reworked from older strata. Because of their sparse occurrence, no range chart was drafted to show species distribution.

The only significant accumulation of coccoliths occurred in discrete intervals of Cores 31 to 33 , where some strongly etched nannofossil oozes are present. The greatest diversity was noted in Section 514-32-1, which contained a few astroliths such as Discoaster surculus, D. variabilis, and a few four-to six-rayed members of the $D$. brouweri plexus. In general, the occurrences of coccoliths in Hole 514 coincided with warm-water maxima or southerly shifts of the position of the Polar Front as recorded by the radiolarian biofacies (see Weaver, this volume).

\section{EVOLUTION OF BROINSONIA PARCA AND RELATED FORMS}

The evolution of species of Broinsonia in the Upper Cretaceous has been discussed by Forchheimer (1972), Lauer (1975), Verbeek (1977), Perch-Nielsen (1979), Hattner et al. (1980), and Crux (1982). Crux (1982) gives a particularly comprehensive discussion and reviews much of the previous literature. Most authors have examined some type of succession which ends with a form they attribute to $B$. parca. Taxa believed by various authors to be in the evolutionary lineage leading up to that form are not always the same, but many of the same trends are nevertheless noted.

Lauer (1975) noted four changes which took place in Broinsonia through time: (1) increase in size, (2) increasing difference in the diameter of the three layers (rim tiers), (3) reduction in the size of the central area, and (4) reduction in the number of perforations. Unfortunately, only sketches have been provided with the summaries given by Lauer (1975) and Perch-Nielsen (1979). The latter author included data from Prins (unpublished). In the successions studied by Verbeek (1977) and Crux (1982), the central area ornamentation was obscured by secondary calcite overgowths and was difficult or impossible to discern. Verbeek also found it difficult to distinguish changes in the relative diameters of the three rims. Verbeek chose the name $B$. lacunosa Forchheimer, 1972, to describe the lower end member of his lineage and Crux (1982) chose the name B. enormis (Shumenko) Manivit, 1971, to describe his lower 
end member (see "Systematic Paleontology" for further discussion of problems in the taxonomy of Broinsonia).

Hattner et al. (1980) could recognize changes 1, 3, and 4 enumerated by Lauer (1975) in electron micrographs of a succession of forms from a low-latitude site in South Carolina where the floras are quite well preserved. They noted a stratigraphic succession from assemblages dominated by B. furtiva Bukry, 1969 (=B. lacunosa) in the Santonian and earliest Campanian to ones dominated by $B$. parca constricta Hattner et al. (1980) higher up the section. Based on the stratigraphic evidence, they concluded, quite incorrectly it seems (see discussion below), that this also represented a direct evolutionary succession (Hattner et al., 1980, fig. 3). They did distinguish two subspecies of $B$. parca, based on the disposition of the central area perforations and the relative widths of the central area in relation to the margin (the b/a ratio of Verbeek, 1977). The b/a ratio of $B$. parca parca ranged roughly from 1.0 to 2.0 with perforations disposed along both the major and minor axes in at least one central area quadrant. These criteria encompassed all of the features of the holotype of $B$. parca, which consists of a sketch by Stradner (1963). As noted by Crux (1982), the criterion chosen by Verbeek (1977) to distinguish $B$. parca would have excluded the holotype. In B. parca constricta, perforations parallel the major but not the minor axis and the $b / a$ ratio is about 1.0 or less.

A section equivalent in time to the Santonian-lowermost Campanian of the South Carolina section was cored at DSDP Site 511. The succession of forms at this site attributed to the $B$. parca lineage, however, is quite different. The lower part of the section is dominated by a new subspecies, $B$. parca expansa. No $B$. furtiva were noted in any sample. Conversely, no specimens attributable to $B$. parca expansa have been noted in the South Carolina material.

In the Santonian-lower Campanian succession at Site 511 , two of the evolutionary trends noted by Lauer (1975) are evident: (1) reduction in central area perforations and (2) reduction in relative size of the central area. The increase in the width of the outer margin relative to the inner margin of the distal shield noted by Crux (1982) also seems to occur. No overall increase in the size of the specimens is seen, however, nor is there a change in the relative diameters of the three rim tiers.

Wide intraspecific variation is seen within the Falkland Plateau assemblages, however, from the long (179 m) Coniacian-Santonian to lower Campanian section. Specimens in the electron micrographs of Plates 10 and 11 are arranged according to the number of central area perforations. All specimens illustrated are from the top of the section except for two from the base (Pl. 11, Figs. 1 and 6). These latter have high perforation counts, very large central areas, and narrow outer distal margins. Several specimens on Plate 11 from the top of the section have the same characteristics. From those, however, a progression can be traced through the other specimens of the same assemblage. The perforation counts decrease until forms attributable to B. parca parca (Pl.
10, Figs. 3-4) are reached. Further reduction in the number of pores leads to forms that approach $B$. parca constricta (Pl. 10, Figs. 1-2) in that their perforations parallel the major axis only. Their $\mathrm{b} / \mathrm{a}$ ratios, however, remain between 2.0 and 1.0. None of these latter forms meet the criteria for $B$. parca constricta as prescribed by Hattner et al. (1980).

Two possible reasons that no bona fide $B$. parca constricta were encountered at Site 511 are (1) the form is not well developed in the high latitudes, or (2) the nannofossiliferous section at the site did not extend high enough to record the FAD of that subspecies. The evolutionary trend, however, is toward the development of a form approaching $B$. parca constricta (labeled here $B$. spp. aff. $B$. parca constricta). Had the nannofossiliferous section continued into the middle or late Campanian, we may well have seen forms matching the South Carolina representatives of that subspecies. What we have observed at Site 511 can be termed a single-lineage evolutionary species as envisioned by Wiley (1978) and Schafersman (1980) with a continuum from $B$. parca expansa to $B$. parca parca to $B$. parca ssp. aff. B. parca constricta (Fig. 5). The ultrastructural detail of the perforation pattern of $B$. parca expansa is identical to that of $B$. parca constricta. One can conclude, therefore, that $B$. parca expansa rather than $B$. furtiva is the true ancestral form of $B$. parca constricta. We can speculate that the reason $B$. parca expansa has not been previously identified in the lower latitudes is due to the fact that it either (1) originated in the high latitudes and migrated into the low latitudes only during the early Campanian, about the time it developed into B. parca parca, or (2) was always present in the lower latitudes but has not been identified as such because of unfavorable preservation. If the latter is true, it would be present in an overgrown state and lumped with other forms under names such as $B$. enormis. Further research on well-preserved sections would clarify this point.

As to the ancestor of $B$. parca expansa, the Site 511 section may provide a clue by the presence of Thiersteinia eccelesiastica in the Coniacian-Santonian (Fig. 5). This form has a pore and margin ultrastructure very similar to $B$. parca expansa and is a likely candidate to be the progenitor of the $B$. parca lineage.

The stratigraphic succession at the top of the Cretaceous of the Falkland Plateau (Fig. 5) could be interpreted to suggest that the $B$. parca species lineage in turn gave rise to Arkhangelskiella cribrata, which is present in the Maestrichtian of Hole 327A (Wise and Wind, 1977, pl. 26, fig. 6). A. cribrata has not yet been observed in the lower Campanian-Santonian of the Falkland Plateau within the stratigraphic range of $B$. par$c a$, and both taxa have similar pore ultrastructures. A direct succession from $B$. parca to $A$. cribrata, however, would require an increase in the width of the outer distal margin in relation to the inner distal margin, a change in the ultrastructural configuration of the latter, and a reorientation of the minor axis suture to a slightly asymmetric position (slanting from upper right to lower left in distal view). In other localities, however, the asymmetric medium suture and the multiperforate round 


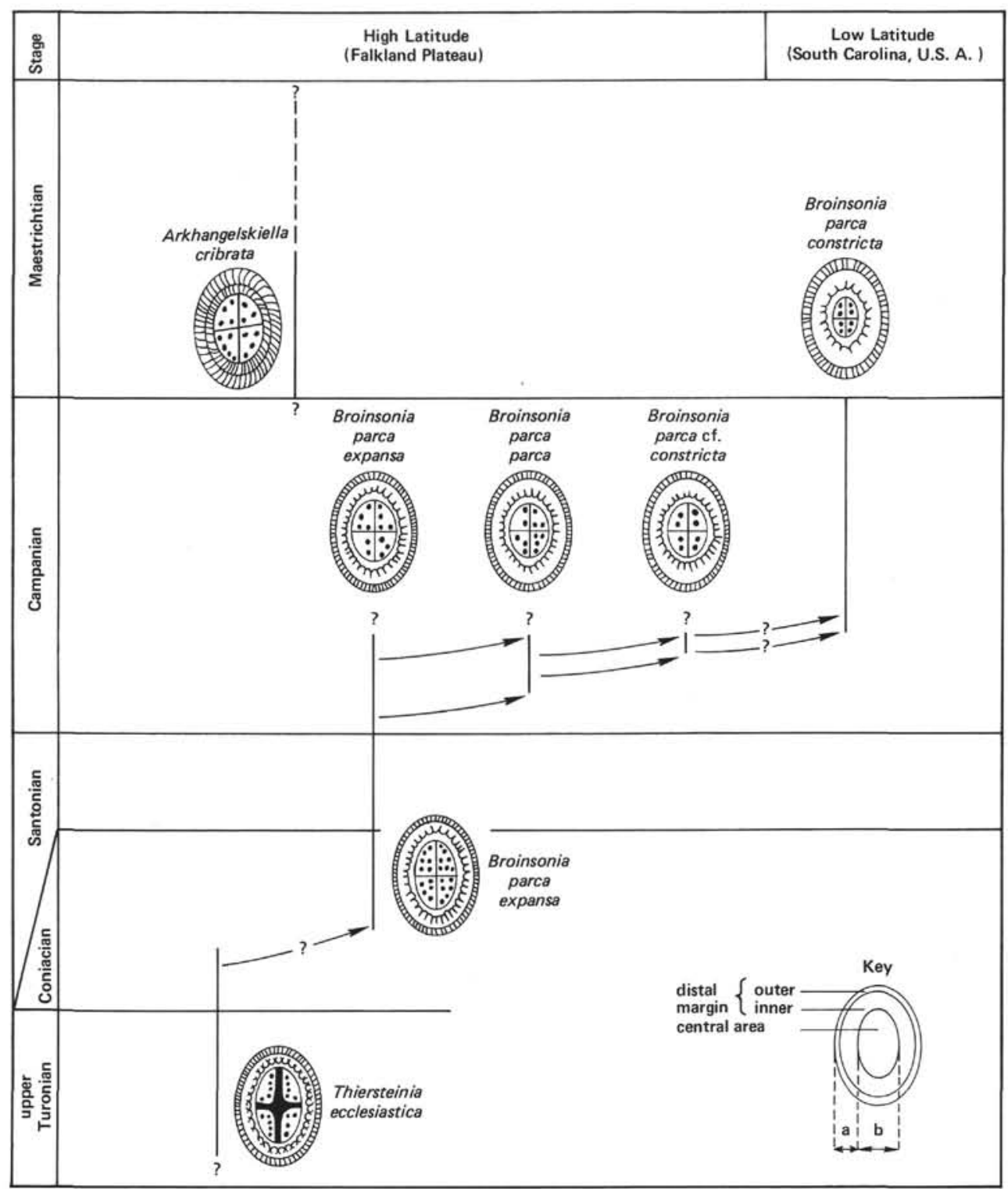

Figure 5. Stratigraphic and presumed phylogenetic relationships among Broinsonia parca and related taxa. All figures are distal views.

pores are already developed in $A$. specillata Vekshina, 1959 , by Santonian-early Campanian times (Hattner and Wise, 1980; see also the Arkhangelskiella Group 2 of Lauer, 1975). A. specillata, therefore, seems to be a more likely ancestor for $A$. cribrata than does $B$. parca. The reason for the apparent absence of $A$. specillata in the lower Campanian of the Falkland Plateau is not clear at the present time.

One conclusion that can be drawn from this discussion is that in phylogenetic studies, it may be necessary to study the entire geographic range of a group, to the extent that it is possible. Major steps in the evolution of some groups such as Broinsonia may have taken place in the higher rather than the lower latitudes. Conversely, it may develop that the major development of Arkhangelskiella occurred in the low rather than the high latitudes.

\section{SYSTEMATIC PALEONTOLOGY}

Species treated here are also listed in Appendix A. See the Introduction for sources of the taxonomic citations that are not listed in the references to this chapter. All taxa below are arranged alphabetically by generic epithets.

\section{Cenozoic}

Genus CHIASMOLITHUS Hay, Mohler, and Wade, 1966

Chiasmolithus solitus (Bramlette and Sullivan) Locker var. inversus Wise and Wiegand, $\mathrm{n}$. var. (Plate 8, Figs. 1-3)

Diagnosis. Variety of Chiasmolithus solitus in which the continuous central crossbar in distal view slants from the upper left to the lower right.

Remarks. This variety represents a small fraction of the total population. The genetic or ecologic factors which cause a reversal in the attitude of the continuous central bar are not known. 
Occurrence. Middle Eocene of Hole 512, Falkland Plateau.

Size. Holotype $17 \mu \mathrm{m} \times 13 \mu \mathrm{m}$.

Holotype. Plate 8, Figure 2.

Paratype. Plate 8, Figure 1.

Type locality. Sample $512-7-3,66 \mathrm{~cm}$.

\section{Genus COCCOLITHUS Schwarz, 1894}

Remarks. I have long agreed (Wise, 1973, p. 593) with the concept of the genus Coccolithus as stated by Bukry, (1973b, pp. 676, 677). Bukry viewed the genus Ericsonia as potentially a junior synonym of Coccolithus but outlined a way by which the structural difference of Ericsonia may be retained by recognizing it as a subgenus, Coccolithus (Ericsonia). Romein (1979, p. 105) states that "strictly speaking, Ericsonia is a junior synonym of Coccolithus. The type species of $C$. pelagicus (lectotype, designated by Braarud et al., 1964) shows three cycles in proximal view: distal shield, proximal shield, and wall. It seems justifiable, however, to retain the name Ericsonia for a group of Paleocene and Eocene coccoliths, which have a well-differentiated proximal cycle of the distal shield."

Although I agree with the first sentence of this statement, I do not concur with the idea expressed in the second. If Paleocene and Eocene members of the Coccolithus lineage are to be segregated on the basis of a well-differentiated proximal cycle of what Romein labels the distal shield, then essentially all other members of the lineage must fall within the same category.

The actual shield construction of Coccolithus can be seen in the partially etched and overgrown specimen of $C$. muiri shown in Plate 2, Figure 4 . There is only a single-cycle distal shield but a double-cycle proximal shield. The central area elements are not counted as a cycle of either shield. The elements of the inner cycle of the proximal shield (IP) are supported by an approximately equal number of elements of the outer shield (OP) which are longer and therefore readily visible behind the inner cycle in proximal view. A brief survey of lower to middle Miocene specimens (Plate 3 ) shows the same construction plainly visible in these Neogene specimens. With time, the width of the outer proximal cycle decreases in proportion to the inner proximal cycle until, in modern specimens, it is not as easily discriminated. The outer cycle remains an intricate part of the construction of the proximal shield, however, and it seems artificial to break the lineage between genera at some arbitrary point in the Paleogene or the Neogene based on the widths of the two proximal cycles. Such breaks could be made, however, to denote species or subspecies.

\section{Coccolithus tenuiforatus (Clocchiatti and Jerković) Wise, n. comb.} (Plate 3, Fig. 9)

Basionym. Cruciplacolithus tenuiforatus Clocchiatti and Jerković, 1970 , p. 2, pl. I, figs. 1-3; pl. II, figs. 1-6.

Remarks. As noted by Bukry (1973b, p. 676), it is probably preferable where possible to accord variations in central area structure to specific or intraspecific variability and to reserve rim structure, form, and crystallography as fundamental characteristics of genera.

\section{Genus PSEUDOTRIQUETRORHABDULUS Wise, 1976}

Pseudotriquetrorhabdulus inversus (Bukry and Bramlette) Wise and Constans, emend., n. comb.

Triquetrorhabdulus inversus Bukry and Bramlette, 1969, p. 142, Pl. 1, figs. 9-14. Pseudotriquetrorhabdulus inversus (Bukry and Bramlette) emend. Wise in Wise and Constans, 1976, p. 154, pl. 4, figs. 1-9 (invalid, ICBN Art. 33, par. 4). Wiseorhabdus inversus (Bukry and Bramlette, emend. Wise and Constans) Bukry, 1981, p. 463 (illegitimate, ICBN Art. 63).

Diagnosis. A species of Pseudotriquetrorhabdulus with approximately 6 to 12 keels.

Description. Although this species was originally described as a "three-edged rod," observations via scanning electron microscopy allow its definition to be emended here to account for its construction of 6 to 12 keels arranged in a somewhat crude radial pattern about the long axis. The keels are quite irregular in thickness and width, and seem to have been emplaced as space was available. Their ragged appearance is probably a primary feature of biomineralization but is further accentuated by diagenetic modification (either by etching or secondary overgrowth). Where truncated, the ends of the object are sometimes hollow, indicating that the interior is not completely closed.
Remarks. Illustrations and detailed descriptions of this species are given by Wise and Constans (1976). According to Heck (1982, p. 50), all previous recombinations of this species are invalid; hence it is reemended and recombined here.

\section{Genus RETICULOFENESTRA Hay, Mohler, and Wade, 1966}

Synonym. Dictyococcites Black, 1967

Remarks. As noted from the descriptions below, some species of Reticulofenestra have a set of laths which partially or completely close the central area in line with the distal shield. In addition, there is invariably a set of elements which close the central area of the proximal side. Because the elements on the proximal side can take the shape of grid bars, perforated plates, or both, workers have traditionally had a great deal of difficulty in separating the various forms between the genera Reticulofenestra and Dictyococcites despite emendations to the latter genus by Black (1973) and Backman (1980). The emended description by Backman does not fit Black's genotype (D. danicus Black, 1967), and it is clear that these two authors had widely varying concepts of the genus. In view of the intergeneric variations noted below, there seems to be little profit in separating forms with some type of distal surface cover from those without.

Reticulofenestra bisecta bisecta (Hay, Mohler, and Wade) Roth, 1970 Reticulofenestra bisecta (Hay, Mohler and Wade) Roth, 1970, p. 847, pl. III, fig. 6.

Reticulofenestra bisecta (Hay, Mohler, and Wade) Roth ssp. filewiczii Wise and Wiegand, $n$. ssp.

(Plate 5, Fig. 3; Plate 6, Figs. 1-2)

Reticulofenestra cf. R. pseudoumbilica (Gartner); Edwards and PerchNielsen, 1975, pl. 16, fig. 4; Reticulofenestra sp. aff. $R$. daviesi (Haq); Haq and Lohmann, 1976, Pl. 1, Fig. 7.

Diagnosis. A subspecies of Reticulofenestra bisecta in which the laths over the central area only partially close the center, thereby revealing a perforated plate below when viewed distally.

Remarks. The holotype is a medium-sized specimen whose dimensions are nearly exactly the same as those of the holotype of $R$. bisecta bisecta. The partial closure of the central area may be a trait of highlatitude forms of the species.

Occurrence. Common to abundant in the upper Eocene and Oligocene of Holes 511 and 513A, Falkland Plateau.

Size. Holotype: $8 \mu \mathrm{m} \times 7 \mu \mathrm{m}$; central area $6.5 \times 5 \mu \mathrm{m}$; paratypes approx. $10 \mu \mathrm{m} \times 8 \mu \mathrm{m}$.

Holotype. Plate 6, Figure 2.

Paratypes. Plate 5, Figure 3; Plate 6, Figure 1.

Type locality. Sample $511-18-2,24 \mathrm{~cm}$.

\section{Reticulofenestra daviesii (Haq) Haq, 1971}

(Plate 1, Figs. 4-6; Plate 2, Figs. 2-3; Plate 5, Figs. 1-2, 4)

Remarks. This species is a dominant form in the upper Eocene and Oligocene of the Falkland Plateau. The electron micrographs show that the central area grill is connected to the shield rim by spokes which intersect the shield more or less at all levels between the proximal and distal surfaces, thereby providing some depth to this structure.

Reticulofenestra onusta (Perch-Nielsen) Wise, n. comb.

(Plate 5, Figs. 8-9)

Basionym. Dictyococcites onustus Perch-Nielsen, 1971, p. 29, pl. 20 , figs. $3-4$; pl. 61 , figs. $28-29$.

Remarks. This species does not possess a lath covering in line with the distal shield.

\section{Reticulofenestra perplexa (Burns) Wise, n. comb.}

Basionym. Dictyococcites perplexa Burns, 1975, p. 594, figs. 13, 19-20.

Remarks. Backman (in Heck, 1981a, p. 40) pointed out correctly that Dictyococcites antarcticus Haq, 1976, is a junior synonym of this species. This has escaped most readers' attention, apparently because of scaling errors in Burns's (1975) descriptions. All of Burns's magnifications in his article are overstated by a factor of about 2.5 . The dimensions he attributed the holotype of $D$. perplexa are also over- 
stated by the same factor; thus the holotype measures about 5 to $6 \mu \mathrm{m}$ along the length of the distal surface rather than $18-20 \mu \mathrm{m}$ as originally stated. The revised measurement is similar to those given by $\mathrm{Haq}$ (1976) for $D$. antarcticus ( 4 to $7 \mu \mathrm{m}$, rarely $8 \mu \mathrm{m}$ ). This deduction is arrived at by (1) assuming that the specimen of Isthmolithus recurvus in Burns's figure 17 is an average-sized specimen about $5 \mu \mathrm{m}$ in length, and then (2) making the appropriate calculations to derive the magnifications of all figures on the page.

\section{Reticulofenestra pseudoumbilica pseudoumbilica (Gartner) Gartner, 1969}

\section{Reticulofenestra pseudoumbilica (Gartner) Gartner ssp. gelida} (Geitzenauer) Wise, n. stat.

Basionym. Coccolithus gelidus Geitzenauer, 1972, in Geitzenauer and Huddlestun, 1972, pp. 405-409, pl. I, figs. 1-2, 5-6.

Remarks. Backman (1980, pp. 38-43) analyzed and discussed the relationship between $R$. pseudoumbilica and $R$. gelidus at length, concluding that these were summer and winter morphotypes respectively. The dominance of one species over the other changes markedly in samples from Site 512 for long intervals, suggesting that these are subspecies which predominate in different water masses rather than existing as seasonal morphotypes.

\section{Mesozoic}

\section{Genus ARKHANGELSKIELLA Vekshina, 1959}

Arkhangelskiella cribrata (Gazdzicka) Wise, n. comb.

Arkhangelskiella cymbiformis Vekshina; Wise and Wind, 1977, pl. 26, fig. 6. Broinsonia lata (Nöel) Gazdzicka, 1978, pp. 352-353, pl. 232, figs. 1, 3. Broinsonia cribrata Gazdzicka, 1978, p. 353, pl. 33 , figs. $1-6$.

Remarks. In distal view, the inner and outer cycles of the rim are approximately of equal width. The inner cycle lacks the "square" elements, usually dimpled, described by Bukry (1969) as being characteristic of the genus Broinsonia. As noted by Bukry (1969), Broinsonia is not distinguished from Arkhangelskiella by the number of rim tiers. Both may exhibit a 3-tier rim. A. cribrata may be a descendant of $B$. parca. It has been described only from the Maestrichtian.

\section{Genus BISCUTUM Black, 1959}

Biscutum hattneri Wise, n. sp.

(Plate 17, Fig. 7; Plate 20, Figs. 1-3)

Diagnosis. An elongate species of Biscutum with a wide central area filled by long laths arranged in a narrow diamond that supports a small hollow central spine.

Description. The distal shield is composed of about 25 dimpled and tabbed elements. They are joined to the central area platform in part by an approximately equal number of thin imbricate laths which spiral in a tight counterclockwise pattern. The outer portion of the central platform is composed of squarish ridged and grooved elements inside of which are a set of long laths which form the narrow diamond around the central spine. It is not clear if the perforation in the center of the spine penetrates the central platform; apparently it does not. The width of the central area is about 1.5 times the width of the margin $(b / a$ ratio $=1.5)$. The outline of this highly ogival form has an eccentricity of 1.66 .

Remarks. Named in honor of John G. Hattner for contributions to coccolith biostratigraphy.

Occurrence. Common in at least one level of the Santonian-Coniacian of Hole 511 of the Falkland Plateau.

Size. Holotypes $5.5 \times 3.5 \mu \mathrm{m}$; central area $3.5 \times 1.5$.

Holotype. Plate 20, Figure 1.

Paratypes. Plate 17, Figure 7; Plate 20, Figures 2-3.

Type locality. Sample $511-46-1,100 \mathrm{~cm}$.

\section{Genus BROINSONIA Bukry, 1969}

Remarks. Much confusion concerning the status of species in this genus has developed primarily because of the description of poorly preserved specimens. Secondary calcite overgrowth has been the main culprit, particularly in samples with high carbonate contents. Such overgrowths obscure or obliterate the pore, grid, and bar patterns of the central area, often to the point that it is impossible to observe and compare the delicate ornamentations by which species are discriminated. Bukry (1969) and more recently Hattner and Wise (1980) illustrate the wealth of taxonomically important central area features present in well-preserved specimens. At that level of discrimination, it is impossible to recognize or apply with any assurance names which have been applied to less well-preserved specimens. Thus we will probably never know the true affinity of holotypes described under names such as Arkhangelskiella enormis Shumenko, 1968, Broinsonia bevieri Bukry, 1969, Aspidolithus angustus Noël, 1969, A. latus Noël, 1969, and $A$. signata Noël, 1969 . Such names can be used to some extent in a very broad and arbitrary sense for light microscope work on poorly preserved material. For more detailed work, particularly for taxonomic and phylogenetic studies, well-preserved material and a more precise nomenclature are required. For this type of work, the Cretaceous materials recovered in Hole 511 offer particular promise in that, because of their shallow burial and favorable lithology, their preservation is exceptional for material of this age.

\section{Broinsonia parca expansa Wise and Watkins, n. ssp.}

$$
\text { (Plates 9-11) }
$$

Diagnosis. A subspecies of Broinsonia parca with a large central area whose width in distal view is approximately twice or more than twice the width of the shield margin. The width of the outer distal margin is measurably less than that of the inner distal margin (see Fig. 5 in text for terminology). Within the central area two or more rounded perforations per quadrant are disposed along the major and minor axes. In at least one quadrant perforations extend out along the periphery. The perforations are subdivided by fine processes which resemble a sieve plate with more or less rounded openings.

Description. The width of the outer distal margin of the holotype (Pl. 9, Figs. 1-4) is about a quarter the width of the inner, dimpled distal margin. In other specimens, the outer margin width may approach but does not equal the inner margin width. The perforations are usually subdivided into two or more circular openings (example, Pl. 9, Figs. 2, 5). There are invariably three rim tiers visible in lateral view (Pl. 9, Figs. 3-4).

Differentiation. As defined by Hattner et al. (1980), the central area of Broinsonia parca parca is more restricted, with a width approximately one to two times the width of the distal margin. Central area perforations lie parallel to the major and minor axes only. Two perforations parallel the minor axis in at least one quadrant. The central area of $B$. parca constricta is narrower still, with a width roughly equal to or significantly less than the width of the distal margin. The one to three perforations per quadrant lie approximately parallel to the major axis only. Arkhangelskiella cribrata (Gazdzicka) lacks the "square," usually dimpled inner distal margin elements which Bukry (1969) describes as an essential feature of Broinsonia. In addition, the outer and inner distal margins of this species are approximately of equal width, whereas in $B$. parca expansa, the width of the outer distal margin is measurably less than that of the inner distal margin. No meaningful comparison can be made between $B$. parca expansa and many of the other forms discussed in the remarks under "Genus BROINSONIA" (above) because the central area features of those species are not adequately preserved. In most cases, the central area ornamentation is obscured by calcite overgrowths.

Remarks. Specimens in Plates 10 and 11 are arranged according to the number of central area perforations in order to demonstrate an evolutionary lineage among the subspecies of $B$. parca. See discussion in the text under "Evolution of Broinsonia parca and related forms" for a discussion of the phylogeny of B. parca expansa.

Occurrence. Generally common to abundant in the Santonian to lower Campanian of Hole 511, Falkland Plateau.

Size. 7-13 $\mu \mathrm{m}$ long, 5-8 $\mu \mathrm{m}$ wide.

Holotype. Plate 9, Figures 1-4.

Paratypes. Plate 9, Figure 5; Plate 10, Figures 5-9; Plate 11, Figures $1-9$.

Type locality. Santonian Sample 511-44-5, $40 \mathrm{~cm}$.

\section{Genus CHIASTOZYGUS Gartner, 1968}

\section{Chiastozygus angustus (Stover) Wise, n. comb.} (Plate 25, Figs. 1-2)

Zygolithus angustus Stover, 1966, p. 147, pl. 3, figs. 14-15; pl. 8, fig. 22. Eiffellithus dennisoni Worsley, 1971, p. 1307, pl. 1, figs. 11-13. E. dennisoni? Worsley; Wise and Wind, 1977, pl. 55, figs. 
1-3. Vekshinella angusta (Stover) Verbeek, 1977, p. 96, pl. 6, figs. 11-12.

\section{Genus COROLLITHION Stradner, 1961}

Remarks. Nannofossil specialists have not agreed on any method for subdividing members of this plexus into phylogenetically meaning ful genera (see Rood et al., 1971; Black, 1971, 1973; Noël, 1973; Thierstein, 1973; Medd, 1979; and Grün and Zweili, 1980, for a range of opinions). At present, the example of Thierstein (1973), which maintains the group within one genus, is followed.

Corollithion delftensis (Stradner and Adamiker) Wise, n. comb. (Plate 33, Fig. 3)

Basionym. Zygolithus delftensis Stradner and Adamiker, 1966, p. 338, figs. $8-11$, pl. 2 , fig. 1 .

Corollithion escovillensis (Rood and Barnard) Wise, n. comb.

Basionym. Diadozygus escovillensis Rood and Barnard, 1972, p. 335 , pl. II, fig. 4.

Remarks. Rood and Barnard (1972) described this form from the lower Callovian. Medd (1979) reports it from the lower Oxfordian. In this study a well-preserved specimen was observed in Sample 511-64-4, $73 \mathrm{~cm}$.

Corollithion pauciramosus (Black) Wise, n. comb. (Plate 26, Fig. 3) fig. 47.

Basionym. Stradnerlithus pauciramosus Black, 1973, p. 98, text-

\section{Genus CRETARHABDELLA Black, 1971}

Cretarhabdella lateralis Black, 1971

Cretarhabdella lateralis Black, 1971, p. 400, pl. 31, fig. 5. Ethmorhabdus? frondosus Wind and Wise, 1977, p. 300, pl. 76, figs. 1-2.

\section{Cretarhabdella bergenii Wise and Wiegand, n. sp.} (Plate 27, Fig. 2)

Cretarhabdus sp. Wise and Wind, 1977, p. 300, pl. 70, figs. 1-2.

Diagnosis. A species of Cretarhabdella with six (rarely five) perforations partially encircled by lath-shaped elements arranged asymmetrically with respect to the major and minor axes of the ellipse. The buttresses support a spine.

Remarks. This species was not described previously from Falkland Plateau material by Wise and Wind (1977) because only proximal views were available. Although the holotype is partially obscured by a sediment particle, there is little doubt based on the asymmetry of the central area that this is the species described by Wise and Wind (1977).

Occurrence. Aptian of DSDP Holes 330 and 511 on the Falkland Plateau.

Size. 5-6 $\mu \mathrm{m}$ long, 4-5 $\mu \mathrm{m}$ wide.

Holotype. Plate 27, Figure 2.

Type locality. Sample $511-57-6,4 \mathrm{~cm}$.

\section{Genus CRUCICRIBRUM Black, 1973}

Crucicribrum striatum (Stradner) ssp. constansii

Wise and Parker, n. ssp.

(Plate 23, Figs. 1-4; Plate 24, Figs. 1-6)

Diagnosis. A subspecies of Crucicribrum striatum in which the central area perforations are squarish rather than distinctly round.

Remarks. Named in honor of Richard E. Constans for contributions in coccolith bistratigraphy. This subspecies can be distinguished only in the electron microscope from C. striatum striatum (Stradner) Wise, n. comb. which has distinctly round central area perforations. It is possible that the square perforations of $C$. striatum constansii are the result of secondary diagenesis. If that were so, however, every specimen in our sample would have been affected exactly the same way without exception, a possibility that seems unlikely.

Occurrence. Few to abundant in the late Aptian to middle Albian of Hole 511 of the Falkland Plateau.

Size. 5-6 $\mu \mathrm{m}$ long, 3-4 $\mu \mathrm{m}$ wide.

Holotype. Plate 23, Figure 1.
Paratypes. Plate 23, Figures 2-4; Plate 24, Figures 1-6.

Type locality. Sample $511-52-6,58 \mathrm{~cm}$.

Crucicribrum striatum striatum (Stradner) Wise, n. comb.

Arkhangelskiella striata Stradner, 1963, p. 176, pl. 1, fig. 1. non A. striata Stradner, Stover, 1966, p. 137, pl. 2, figs. 3-4. A. erratica Stover, 1966, p. 137, pl. 2, fig. 10; pl. 8, fig. 14. Zygolithus striatus (Stradner) Stradner, Adamiker, and Maresch, 1968, partim p. 38, pl. 33, figs. 1-2; non pl. 32, fig. 1-2. non Gartnerago striatum (Stradner) Forchheimer, 1972, p. 29, pl. 3, figs. 1-3. non Cretarhabdus striatus (Stradner) Black, 1973, p. 53, pl. 17, figs. 3-6, 10-11. Crucicribrum anglicum Black, 1973, p. 62, pl. 22, figs. 11-15. non Gartnerago striatum (Stradner) Forchheimer, Thierstein, 1974, p. 640, pl. 4, figs, 1-15. Broinsonia stenostaurion Hill, 1976 , pp. $127-128$, pl. 3 , figs. 13-24; pl. 13, figs. 12-14. non Cretarhabdus striatus (Stradner) Black, Taylor, 1982, p. 64, pl. 4.3, figs. 15-16. Gartnerago striatum (Stradner) Forchheimer, Taylor, 1982 , p. 68 , pl. 4.5 , figs. $12,15-16$.

Remarks. Measurements of the length of Stradner's 1963 holotype of Arkhangelskiella striata are ambiguous. If the magnification given in the text (Stradner, 1963, p. 176) is used, the length would be a little less than $5 \mu \mathrm{m}$. If the bar scale which accompanies the hand-drawn figures on his plate 1 is used, the length is $11.8 \mu \mathrm{m}$. This ambiguity is probably the source of much of the confusion which surrounds this species. The holotype was described from the lower Albian of a well in Holland which was later restudied along with another Dutch well by Stradner et al. (1968). In that study the authors reillustrate the species by light and transmission electron micrographs in their plate 33. Measurements of these suggest a length of about $8 \mu \mathrm{m}$. The electron micrograph also reveals a vague cross in the major and minor axes consistent with the holotype and a rim constructed of spirally arranged, imbricate laths which differ from the rim in the sketch of the holotype. This probably has been a second source of confusion regarding this species. The central area perforation pattern of the specimens illustrated by Stradner et al. (1968), however, is the same as in the holotype and the more recently illustrated specimens are from deposits of the same age. Excellent micrographs of this species have since been provided by Black (1973) and Taylor (1982, pl. 4.5, figs. 12, 15-16; non pl. 4.3, figs. 15-16). In the meantime, various forms of Gartnerago and Cretarhabdus have been attributed to this species depending on individual authors' interpretations of the holotype.

According to Perch-Nielsen (1979), Sissingh (1977), and the present study, no species of Gartnerago have been reported from the lower Albian, the strata from which the holotype was described. Nor has Gartnerago been reported from the middle Albian from which the species was reillustrated by Stradner et al. (1968). Cretarhabdus loriei Gartner, 1968, does occur within that interval, but Stradner's holotype of Crucicribrum striatum has a narrower rim and nearly twice the number of elements as does Cretarhabdus loriei. It is understandable that Stradner (1963) could not decipher accurately the rim structure of C. striata since it can only be discerned in electron micrographs. I have chosen to accept the reillustrated specimens by Stradner et al. (1968) as the ultimate guide to the true identity of the species.

\section{Genus FLABELLITES Thierstein, 1972 \\ Flabellites oblongus (Bukry) Crux, 1982 (Plate 26, Fig. 5)}

Remarks: Crux (1982) transferred this species to the genus Flabellites based on the asymmetric elongation of elements of the distal shield. This combination is supported by the fact that in cross-polarized light, a well-developed flange on this species does not exhibit a high luminescence as is characteristic of the shields of species of Watznaueria.

\section{Genus GARTNERAGO Bukry, 1969}

Gartnerago confossus (Noël) Noël, 1972

(Plate 12, Fig. 1; Plate 18, Figs. 6-9)

Remarks. Members of the genus Gartnerago, like those of Broinsonia, are highly susceptible to secondary calcite overgrowths (Thierstein, 1974). Specimens in the Upper Cretaceous of the Falkland Plateau were remarkably well preserved. In the light and electron micro- 
scope, it is easy to separate the two species present, $G$. costatum and $G$. confossus. The latter name was chosen because it is the first to be applied to specimens for which a discernible perforation pattern can be distinguished.

\section{Genus GRANTARHABDUS Black, 1971, emend. Wise}

Type species. Grantarhabdus meddii Black, 1971

Emended diagnosis. A genus of Podorhabdaceae with four buttresses which are oblique to the principal axes of the elliptical coccolith, and which meet in the center to form a solid spine. The areas between buttresses may be open or further subdivided.

Remarks. The definition is modified from the original wording which specified for the central area "four windows separated by buttresses" (Black, 1971, p. 403). As originally stated, the genus would not accommodate species which have the same shield and stem construction but for which the four windows between buttresses are further subdivided.

\section{Grantarhabdus camaratus (Bukry) Wise, n. comb.}

Basionym. Ethmorhabdus camaratus Bukry, 1969, p. 37, pl. 15, fig. 10-12.

Remarks. Scanning electron micrographs (Grün and Zweili, 1980, pl. 8, figs. 1-9) show that in Ethmorhabdus, the central area structure is attached to the margin well below the distal surface of the margin. Electron micrographs by Bukry (1969) and Hattner and Wise (1980) show that in $G$. camaratus the central area structure intersects the margin at the level of the distal surface. This and the other analogous features of the stem and buttresses suggest close affinity with the cretarhabdids of which Grantarhabdus is a member.

Bukry (1969) further noted that the perforation structures of the central area of $G$. camaratus are similar to those of Nephrolithus species. In particular, they resemble those of $N$. corystus Wind (in press), the Campanian to middle Maestrichtian ancestor of $N$. frequens of the upper Maestrichtian. $N$. corystus has a spine and truncated buttresses whereas $N$. frequens has neither. The major evolutionary changes needed for a transition from $G$. camaratus to $N$. corystus would be the development of a different and asymmetric (kidney-shaped) margin and a reorientation of the cross-bar buttresses into the major and minor axes of the coccolith.

\section{Genus PERCIVALIA Bukry, 1969 \\ Percivalia fenestrata (Worsley) Wise, n. comb.}

(Plate 28, Fig. 6)

Arkhangelskiella? fenestrata Worsley, 1971, p. 1305, pl. 1, pp. 33-35. Reinhardtites fenestratus (Worsley) Thierstein in Roth and Thierstein, 1972 , pl. 8 , figs. $1-12$, p. 437.

Remarks. Preservation of coccoliths is not particularly good in the sample $(511-59-1,82 \mathrm{~cm})$ from which the specimen in Plate 28 was figured; overgrowths have apparently altered the ultrastructural characteristics of the central area of the specimen although a crude concentric elliptical pattern of elements seems to be present. This is a characteristic of forms assigned to the monogeneric Family Percivaliaceae by Black (1973). The specimen figured here resembles most closely one figured by Roth and Thierstein (1972) in their plate 8, figure 9 . The margin consists of a simple eiffellithid rim with elements imbricated clockwise. Only one species assigned by Black (1973) to the genus Percivalia, $P$. tessellata Black, 1973, has a rim similar to the one illustrated here. The assignment of these forms to Percivalia, therefore, is not entirely satisfactory, but must suffice until more and better preserved specimens are available that will allow a better description of the ultrastructural characteristics.

\section{Genus PETRARHABDUS Wind and Wise, n. gen.}

Type species. Petrarhabdus copulatus (Deflandre) Wind and Wise, n. comb.

Diagnosis. A nannolith with a placolith base surmounted by a distal structure consisting of a rosette of angular rhombs. The rosette may be developed into a tetralith-like structure.

Description. The round to elliptical placolith base is composed of imbricate elements which overlap in a counterclockwise direction in distal view. The size of the rosette is variable. It may occupy the central area only or may extend beyond the width of the shield.
Remarks. The name is derived from the Greek, petra (pronounced "'Peter"), meaning stone.

Petrarhabdus copulatus (Deflandre) Wind and Wise, n. comb. (Plate 13, Fig. 6)

Tetralithus copulatus Deflandre, 1959, p. 138, pl. 3, figs. 19-24. T. copulatus Deflandre, Wind, 1975, pp. 265-268, figs. 1-2.

Remarks. The original illustrations by Deflandre are hand-drawn and rather schematic. The species has been reillustrated by correlated light microscopy and scanning electron microscopy by Wind (1975), who gives a detailed description. The dimensions and number of elements in some of Wind's specimens (his figs. 1a-11) are remarkably close to those of Deflandre's holotype (10-12.5 $\mu \mathrm{m}$ long, shield composed of about 20 elements). Not described by Deflandre is the existence of a double shield (placolith) base.

In his initial survey, Wind (1975) traced the geographic range of the species in the Campanian-Maestrichtian to DSDP sites as far as $40^{\circ} \mathrm{S}$ latitude. The present paper is the first report on the taxon as far poleward as the Falkland Plateau, where it occurs rarely in the Campanian.

\section{Genus POL YPODORHABDUS Noël, 1965 \\ Polypodorhabdus escaigi Noël, 1965}

Remarks. The distinction between Polypodorhabdus escaigi and P. madingleyensis Black, 1968, is made in different ways by different workers (examples, Medd, 1979, Hamilton, 1982, p. 36) or not at all (Grün and Zweili, 1980). As shown in Plate 33, Figure 5 and in one of Noel's paratypes (Noël, 1965, p. X, fig. 7), P. escaigi can possess an accessory set of outer rim elements to form a two-cycle margin reminiscent of Cretarhabdus. The only consistent distinction I can see between $P$. madingleyensis and $P$. escaigi is a distinct inward tilt of the distal shield margin of the latter, a feature which is particularly noticeable in scanning electron micrographs (examples, Wise and Wind, 1977, pl. 77, figs. 1-2; Grün and Zweili, 1980, pl. 9; Hamilton, 1982, pl. 3.3, fig. 11). This pronounced inward tilt of the distal shield margin causes a marked separation between it and the proximal shield margin which tilts proximally (see Wise and Wind, pl. 77, fig. 1). This in turn may account for what appears to be a weaker birefringence pattern in polarized light compared to $P$. madingleyensis. Unfortunately, the distinction between the two species is rather vague and their separation may not be warranted for routine light microscope work.

\section{Genus REINHARDTITES Perch-Nielsen, 1968}

Reinhardtites elegans (Gartner) Wise, $\mathbf{n}$. comb.

Basionym. Zygodiscus elegans Gartner, 1968, p. 32, pl. 10, figs. 3-6; pl. 12, figs. 3a-c, $4 a-c ;$ pl. 27 , fig. 1 .

Remarks. The differences between Reinhardtites elegans and $R$. anthophorus are discussed at length by Hattner and Wise (1980, pp. $68,69)$. The differences are (1) in the size of the terminal structure of the spine (the calyx) which is quite large in $R$. anthophorus, and (2) possibly in the size of the openings on either side of the central bar. Unfortunately, few micrographs exist which show both the termina structure of the spine as well as the size of the openings on either side of the central bar. Many specimens lack intact stems. The holotype of $R$. anthophorus published by Deflandre (1959) shows only the terminal stem structure, not the size of the rim opening, hence there has been a fair amount of confusion surrounding that species.

\section{Genus SERIBISCUTUM Filewicz, Wind, and Wise} in Wise and Wind, 1977

Type species. Seribiscutum bijugum Filewicz, Wind, and Wise in Wise and Wind, 1977.

Diagnosis. Elliptical coccoliths with two monocyclic shields composed of nonimbricate to slightly imbricate elements surrounding a central area partially closed by large blocky elements and granules.

Seribiscutum salebrosum (Black) Wise, n. comb. fig. 4 . 
Seribiscutum pinnatum (Black) Wise, n. comb. fig. 5 .

Basionym. Cruciplacolithus pinnatus Black, 1971, p. 397, pl. 30,

\section{Genus THIERSTEINIA Wise and Watkins, n. gen.}

Type species. Thiersteinia ecclesiastica Wise and Watkins, n. sp. Diagnosis. A genus of the Arkhangelskielloidae characterized by a three-tiered Broinsonia-like margin and a perforated central area surmounted on the distal surface by a solid spine. The spine is supported by buttresses which form a cross along the major and minor axes of the central area.

Description. Perforations of the central area are often further subdivided into two to three subperforations of the type often seen in Broinsonia parca. When intact, the spine projects well beyond the distal surface. Elements of the inner distal margin are the irregularly margined, "square," dimpled elements described by Bukry (1969, p. 21) for the genus Broinsonia.

Differentiation. This genus is similar to the genus Broinsonia in many respects except for the presence of a prominant spine and crossbars on the distal surface.

Remarks. Named in honor of Hans R. Thierstein for pioneering work in Cretaceous coccolith biostratigraphy.

\section{Thiersteinia ecclesiastica Wise and Watkins, n. sp.} (Plates 14-16; Plate 17, Figs. 1-4)

?Broinsonia furtiva Bukry, 1969, Thierstein, 1974, p. 637, pl. 10, figures 7-14; plate 11 , figures $1-8$.

Description. A species of Thiersteinia in which the inner distal margin consists of about 25-30 dimpled elements along side a greater number of outer distal margin elements (numbering about 50). In cross-polarized light the crossbars light up distinctly when rotated in one direction $221^{\circ}$ to the polarizing direction of the microscope and are quite indistinct when rotated $22^{1} \mathrm{2}^{\circ}$ in the opposite direction (PI. 16 , Figs. 3 and 2 respectively). The perforations are generally disposed parallel to the crossbars along the major and minor axes and number rather consistently between 3 and 5 per quadrant. The perforations are subdivided as in $B$. parca, in such a way as on occasion to resemble the shape of church windows, hence the specific epithet. Long, thin, lathshaped elements separate the central area from the inner distal margin. Another set of small, long, imbricate laths are expressed in a clockwise spiral, barely visible where it emanates from the inner distal margin elements at the point that they abut the outer distal margin. The outer distal margin is about one-third to one-quarter the width of the inner distal margin. The width of the central area is about two and one-half (2.5) times the width of the distal margin $(b / a$ ratio $=2.5$ ).

Differentiation. The characteristics of Broinsonia furtiva have been discussed at length by Hattner et al. (1980), who restrict it to forms with large perforations filled by small but prominent crossbars. B. dempta Forchheimer, 1972, possesses a spine but has four empty openings in the central area and a four-tiered rim. It was described from the Cenomanian.

Occurrence. Rare to abundant from the Turonian to the Coniacian-Santonian undifferentiated of the Falkland Plateau (Kamptnerius magnificus and Thiersteinia ecclesiastica zones).

Size. Holotype: $8 \mu \mathrm{m} \times 6 \mu \mathrm{m}$; paratypes, $8-10 \mu \mathrm{m} \times 6-8 \mu \mathrm{m}$.

Holotype. Plate 14, Figures 1-2. 1-4.

Paratypes. Plate 14, Figures 3-4; Plates 15-16; Plate 17, Figures

Type locality. Sample $511-46-1,100 \mathrm{~cm}$.

\section{ACKNOWLEDGMENTS}

Completion of this and other contributions coauthored in this volume by the writer would not have been possible without the enthusiastic, dedicated, and skillful help of a number of FSU graduate students. David K. Watkins, George E. Wiegand, Mary E. Parker, and Steven Knüttel examined samples in the SEM skillfully operated by William I. Miller III, and diligently sought out the various "mystery bugs" that turned up during the light microscope investigations. David K. Watkins also helped construct the range chart for the Jurassic. Comparative samples from the Miocene were kindly provided by Prof. Hans M. Bolli (ETH, Zürich). Dr. Alan W. Medd (University of Leeds, England), David K. Watkins (FSU), and Peter H. Roth (University of Utah) kindly provided preprints of their forthcoming DSDP
Leg 76 contributions. Ms. Parker headed a group, which included Robert O. Case (on loan from Princeton University), Mary Anne Holmes, and Cindy Wise, that prepared the plates and manuscript. The micrographs were printed by Kim Riddle and Jackie Lloyd, who received much helpful advice from Dennis S. Cassidy. Sharon Reeves and Edith Fleer helped type the manuscript, which was critically reviewed by Dr. Hans R. Thierstein (Scripps Institution of Oceanography). I would like to thank my Leg 71 shipmates for much stimulating and helpful discussion, especially John Usher whose thorough ground work as Shipboard Staff Representative made my job of bringing the volume to completion much easier. Last I would like to thank the staff and crew of Glomar Challenger, especially Captain Loyd Dill, with whom I have spent six pleasurable months in Arctic and Antarctic waters, and who has always guided us safely through sometimes perilous seas. Support for the research was provided by National Science Foundation Grant DPP 80-20382.

\section{REFERENCES}

Backman, J., 1980. Miocene-Pliocene nannofossils and sedimentation rates in the Hatton-Rockall Basin, NE Atlantic Ocean. Stockholm Contrib. Geol., 36:1-91.

Barker, P. F., Dalziel, I. W. D., et al., 1977. Init. Repts. DSDP, 36: Washington (U.S. Govt. Printing Office).

Barnard, T., and Hay, W. W., 1974. On Jurassic coccoliths: A tentative zonation of the Jurassic of Southern England and North France. Ecolgae Geol. Helv., 67:563-585.

Black, M., 1971. Coccoliths of the Speeton Clay and Sutterby Marl. Yokshire Geol. Soc. Proc., 38:381-424.

1973. British Lower Cretaceous coccoliths: I. Gault Clay, II, Paleontograph. Soc. Monogr., 127:49-112.

Bolli, H. M., and Krasheninnikov, V. A., 1977. Problems in Paleogene and Neogene correlations based on planktonic foraminifera. Micropaleontology, 23:436-452.

Braarud, T., Bramlette, M. N., Deflandre, G., Kamptner, E., Loeblich, A. R., Jr., Martini, E., and Tappan, H., 1964. Rhabdosphae$r a$ Haeckel, 1894 (Coccolithophorida) proposed validation under the plenary powers and designation of a lectotype for Coccolithus oceanicus Schwarz, 1894. Bull. Zool. Nomencl., 21:379-400.

Bukry, D. 1969. Upper Cretaceous Coccoliths from Texas and Europe. Univ. Kans. Paleontol. Contrib. 51, Protista 2.

1973a. Low-latitude coccolith biostratigraphic zonation. In Edgar, N. T., Saunders, J. B., et al., Init. Repts. DSDP, 15: Washington (U.S. Govt. Printing Office), 685-703.

1973b. Coccolith stratigraphy, Eastern Equatorial Pacific, Leg 16, Deep Sea Drilling Project. In van Andel, Tj. H., Heath, G. R., et al., Init. Repts. DSDP, 16: Washington (U.S. Govt. Printing Office), 653-711.

Bukry, D., and Bramlette, M. N., 1969. Some new and stratigraphically useful calcareous nannofossils of the Cenozoic. Tulane Stud. Geol. Paleontol., 7:131-142.

Burns, D. A., 1975. Distribution, abundance and preservation of nannofossils in Eocene to Recent Antarctic sediments. N. Z. J. Geol. Geophys., 18:583-595.

Čepek, P., and Hay, W. W., 1969. Calcareous nannoplankton and biostratigraphic subdivision of the Upper Cretaceous. Trans. Gulf Coast Assoc. Geol. Soc., 19:323-336.

Ciesielski, P. F., Sliter, W. V., Wind, F. H., and Wise, S. W., 1977. Paleoenvironmental analysis and correlation of a Cretaceous Islas Orcadas core from the Falkland Plateau, Southwest Atlantic. Mar. Micropaleontol., 2:27-34.

Ciesielski, P. F., and Wise, S. W., 1977. Geologic history of the Maurice Ewing Bank of the Falkland Plateau (Southwest Atlantic sector of the Southern Ocean) based on piston and drill cores. Mar. Geol., 25:175-207.

Clocchiatti, M., and Jerković, L., 1970. Cruciplacolithus tenuiforatus nouvelle espèce de coccolithophoride du Miocène D'Algérie et de Yougoslavie. Cah. Micropaleontol., Ser. 2, No. 2, C.N.R.S. No. 467:1-6.

Crux, J. A., 1982. Upper Cretaceous (Cenomanian to Campanian) calcareous nannofossils. In Lord, A. R. (Ed.), A Stratigraphical Index of Calcareous Nannofossils: Chichester (Ellis Horwood), pp. 81-135.

Deflandre, G., 1959. Sur les nannofossiles calcaires et leur systématique. Rev. Micropaléontol, 2:127-152. 
Edwards, A. R., 1971. A calcareous nannoplankton zonation of the New Zealand Paleogene. In Farinacci, A. (Ed.), Proc. II Planktonic Conf. (Vol. 1): Rome (Edizioni Tecnoscienza), pp. 381-519.

Forchheimer, S., 1972. Scanning electron microscope studies of Cretaceous coccoliths from Köpingsberg Borehole No. 1, S. E. Sweden. Atsb. Sver. Geol. Unders. C 668, 65/14:1-141.

Gartner, S., Jr., 1968. Coccoliths and Related Calcareous Nannofossils from Upper Cretaceous Deposits of Texas and Arkansas. Univ. Kans. Paleontol. Contrib. 48, Protista 1.

Gazdzicka, E., 1978. Calcareous nannoplankton from the uppermost Cretaceous and Paleogene deposits of the Lublin Upland. Acta Geol. Pol., 28:335-375.

Geitzenauer, K. R., and Huddlestun, P., 1972. An upper PliocenePleistocene calcareous nannoplankton flora from a subantarctic Pacific deep-sea core. Micropaleontology, 18:405-409.

Grün, W., and Zweili, F., 1980. Das Kalkige Nannoplankton der Dogger-Malm-Grenze im Berner Jura bei Liesbert (Schweiz). Jahrb. Geol. B.-A. 123:231-341.

Hamilton, G. B., 1982. Triassic and Jurassic calcareous nannofossils. In Lord, A. R., (Ed.), A Stratigraphical Index of Calcareous Nannofossils: Chichester (Ellis Horwood), pp. 17-39.

Haq, B. U., 1976. Coccoliths in cores from the Bellingshausen Abyssal Plain and Antarctic Continental Rise (DSDP Leg 35). In Hollister, C. D., Craddock, C., et al., Init. Repts. DSDP 35: Washington (U.S. Govt. Printing Office), 557-568.

1980. Biogeographic history of Miocene calcareous nannoplankton and paleoceanography of the Atlantic Ocean. Micropaleontology, 26:414-443.

Haq, B. U., Lohmann, G. P., and Wise, S. W., 1977. Calcareous nannoplankton biogeography and its paleoclimatic implications: Cenozoic of the Falkland Plateau (DSDP Leg 36) and Miocene of the Atlantic Ocean. In Barker, P. F., Dalziel, I. W. D., et al., Init. Repts. DSDP, 36: Washington (U.S. Govt. Printing Office), 745-760.

Haq, B. U., Perch-Nielsen, K., and Lohmann, G. P., 1977. Contribution to the Paleocene calcareous nannofossil biogeography of the central and southwest Atlantic Ocean (Ceará Rise and São Paulo Plateau, DSDP Leg 39). In Supko, P. R., and Perch-Nielsen, K., et al., Init. Repts. DSDP, 39: Washington (U.S. Govt. Printing Office), 841-848.

Harris, W. K., 1977. Palynology of cores from Deep Sea Drilling Sites 327,328 , and 330, South Atlantic Ocean. In Barker, P. F., Dalziel, I. W. D., et al., Init. Repts. DSDP, 36: Washington (U.S. Govt. Printing Office), 761-816.

Hattner, J. G., Wind, F. H., and Wise, S. W., 1980. The Santonian/ Campanian boundary: Comparison of nearshore-offshore calcareous nannofossil assemblages. Cah. Micropaleontol., No. 3 (1980), 9-26.

Hattner, J. G., and Wise, S. W., 1980. Upper Cretaceous calcareous nannofossil biostratigraphy of South Carolina. S. C. Geol., 24: 41-117.

Hay, W. W., 1970. Calcareous nannofossils from cores recovered on Leg 4. In Bader, R. G., Gerard, R. D., et al., Init. Repts. DSDP, 4: Washington (U.S. Govt. Printing Office), 455-501.

Heck, S. E. van, 1979a. Bibliography and taxa of calcareous nannoplankton. Int. Nannoplankton Assoc. Newsl., 1:AB1-5, A1-12, B1-27.

1979b. Bibliography and taxa of calcareous nannoplankton. Int. Nannoplankton Assoc. Newsl., 1:AB VI, A13-28, B28-42.

, 1980a. Bibliography and taxa of calcareous nannoplankton. Int. Nannoplankton Assoc. Newsl., 2:5-34.

1980b. Bibliography and taxa of calcareous nannoplankton. Int. Nannoplankton Assoc. Newsl., 2:43-81.

1981a. Bibliography and taxa of calcareous nannoplankton. Int. Nannoplankton Assoc. Newsl., 3:4-41.

1981b. Bibliography and taxa of calcareous nannoplankton. Int. Nannoplankton Assoc. Newsl., 3:51-86.

1982. Bibliography and taxa of calcareous nannoplankton. Int. Nannoplankton Assoc. Newsl., 4:7-50.

Jones, D. L., and Plafker, G., 1977. Mesozoic megafossils from DSDP Hole 327A and Site 330 on the eastern Falkland Plateau. In Barker, P. F., Dalziel, I. W. D., et al., Init. Repts. DSDP, 36: Washington (U.S. Govt. Printing Office), 845-856.
Lauer, G., 1975. Evolutionary trends in the Arkhangelskiellaceae (calcareous nannoplankton) of the Upper Cretaceous of Central Oman, S. E. Arabia. Arch. Sci. Genève, 28:259-262 (Appendix to Noèl and Perch-Nielsen, 1975).

Loeblich, A. R., Jr., and Tappan, H., 1966. Annotated index and bibliography of the calcareous nannoplankton. Phycologia, 5:81-216. 1968. Annotated index and bibliography of the calcareous nannoplankton III. J. Paleontol, 42:584-598. 1969. Annotated index and bibliography of the calcareous nannoplankton III. J. Paleontol, 43:568-588. 1970a. Annotated index and bibliography of the calcareous nannoplankton IV. J. Paleontol, 44:558-574. $1970 \mathrm{~b}$. Annotated index and bibliography of the calcareous nannoplankton VI. Phycologia, 9:157-174. , 1971. Annotated index and bibliography of the calcareous nannoplankton VI. Phycologia, 10:315-339. 1973. Annotated index and bibliography of the calcareous nannoplankton VII. J. Paleontol, 47:715-759.

Manivit, H., 1971. Nannofossiles calcaires du Crétacé français (Aptian-Maestrichtian). Essai de biozonation appuyée sur les stratotypes [Thèse Doctorate d'Etat]. Fac. Sci. d'Orsay.

Manivit, H., Perch-Nielsen, K., Prins, B., and Verbeek, J. W., 1977. Mid Cretaceous calcareous nannofossil biostratigraphy. Proc. $K$. Ned. Akad. Wet. Ser. B., 80(3):169-181.

Medd, A. W., 1971. Some Middle and Upper Jurassic Coccolithophoridea from England and France. In Farinacci, A. (Ed.), Proc. II Planktonic Conf. (Vol. 2): Rome (Edizioni Tecnoscienza), 11: 821-846.

1979. The Upper Jurassic coccoliths from the Haddenham and Gamlingay boreholes, Cambridgeshire, England. Eclogae Geol. Helv., 72:19-109.

, in press. Circum-Atlantic Middle Jurassic to basal Cretaceous calcareous nannofossil biostratigraphy. In Sheridan, R. E,, Gradstein, F. M., et al., Init. Repts. DSDP, 76: Washington (U.S. Govt. Printing Office).

Noel, D., 1965. Sur les Coccolithes du Jurassique Europeen et d'Afrique du Nord: Paris (C.N.R.S.).

1973. Nannofossiles calcaires de sédiments jurassique finement lamines. Bull. Mus. Natl. Hist. Nat. 3 Ser., 75:95-155.

Noël, D., and Manivit, H., 1978. Nannofacies de "black shales" aptiennes et albiennes d'Atlantique sud (legs 3B et 40). Intérêt sédimentologique. Bull. Soc. Geol. France (7), 20(no. 4):491-502.

Okada, H., and Bukry, D., 1980. Supplementary modification and introduction of code numbers to the "Low-latitude coccolith biostratigraphic zonation" (Bukry, 1973; 1975). Mar. Micropaleontol., 5:321-325.

Perch-Nielsen, K., 1979. Calcareous nannofossils from the Cretaceous between the North Sea and the Mediterranean. Aspecte der Kriede Europas: Stuttgart, IUGS Series A, 6:223-272.

Romein, A. J. T., 1979. Lineages in Early Paleogene calcareous nannoplankton. Utrecht Micropaleontol. Bull., 22:1-231.

Rood, A. P., and Barnard, T., 1972. On Jurassic coccoliths: Stephanolithion, Diadozygus and related genera. Eclogae Geol. Helv., 64: 327-342.

Rood, A. P., Hay, W. W., and Barnard, T., 1971. Electron microscope studies of Oxford clay coccoliths. Eclogae Geol. Helv., 64: 245-272.

Roth, P. H., 1978. Cretaceous nannoplankton biostratigraphy and oceanography of the northwestern Atlantic Ocean. In Benson, W. E., Sheridan, R. E., et al., Init. Repts. DSDP, 44: Washington (U.S. Govt. Printing Office), 731-760.

Roth, P. H., and Bowdler, J. L., 1981. Middle Cretaceous calcareous nannoplankton biogeography and oceanography of the Atlantic Ocean. In Warme, J. E., Douglas, R. G., and Winterer, E. L. (Eds.), The Deep Sea Drilling Project: A Decade of Progress. Soc. Econ. Paleontol. Mineral, Spec. Publ., 32:517-546.

Roth, P. H., Medd, A. W., and Watkins, D. K., in press. Jurassic nannofossil zonation, an overview. In Sheridan, R. E., Gradstein, F. M., et al., Init. Repts. DSDP, 76: Washington (U.S. Govt. Printing Office).

Roth, P. H., and Thierstein, H., 1972. Calcareous nannoplankton: Leg 14 of the Deep Sea Drilling Project. In Hayes, D. E., Pimm, A. C., et al., Init. Repts. DSDP, 14: Washington (U.S. Govt. Printing Office), 421-485. 
Schafersman, S. D., 1980. Biostratigraphic problems generated by Deep Sea Coring-biosystematic analysis, evolutionary species, and non-validity of lineage zones. Am. Assoc. Pet. Geol. Bull., 64:781. (Abstract)

Shipboard Scientific Party, with Harris, W., and Sliter, W. V., 1977. Evolution of the Southwestern Atlantic Ocean Basin: Results of Leg 36, Deep Sea Drilling Project. In Barker, P. F., Dalziel, I. W. D., et al., Init. Repts. DSDP, 36: Washington (U.S. Govt. Printing Office), 993-1014.

Sissingh, W., 1977. Biostratigraphy of Cretaceous calcareous nannoplankton. Geol. Mijnbouw, 56:37-65.

Sliter, W. V., 1977. Cretaceous foraminifers from the southwestern Atlantic Ocean, Leg 36, Deep Sea Drilling Project. In Barker, P. F., Dalziel, I. W. D., et al., Init. Repts. DSDP, 36: Washington (U.S. Govt. Printing Office), 519-573.

Stover, L. E., 1966. Cretaceous coccoliths and associated nannofossils from France and the Netherlands. Micropaleontology, 12: 133-167.

Stradner, H., 1963. New Contributions to Mesozoic Stratigraphy by Means of Nannofossils. Sixth World Pet. Congr. Proc. (Frankfurt-a.-M.), Sect. 1, Paper 4.

Stradner, H., and Adamiker, D., 1966. Nannofossilien aus Bohrkernen und ihre eletronenmikroskopische Bearbeitung. Erdöl-Erdgas-Z., 82:330-341.

Stradner, H., Adamiker, D., and Maresch, O., 1968. Electron microscope studies on Albian calcareous nannoplankton from the Delft 2 and Leidschendam 1 Deepwells, Holland. Verh. K. Ned. Akad. Wet., Afd. Natuurkd., Reeks 1, 24:1-51.

Taylor, R. J., 1982. Lower Cretaceous (Ryazanian to Albian) calcareous nannofossils. In Lord, A. R. (Ed.), A Stratigraphical Index of Calcareous Nannofossils: Chichester (Ellis Horwood), pp. 40-80.

Thierstein, H. R., 1973. Lower Cretaceous calcareous nannoplankton biostratigraphy. Abh. Geol. Bundesanst Wien, 29:1-52.

1974. Calcareous nannoplankton-Leg 26, Deep Sea Drilling Project. In Davies, T. A., Luyendyk, B. P., et al., Init. Repts. DSDP, 26: Washington (U.S. Govt. Printing Office), 619-668. 1981. Late Cretaceous nannoplankton and the change at the Cretaceous/Tertiary boundary. In Warme, J. E., Douglas, R. G., and Winterer, E. L. (Eds.), The Deep Sea Drilling Project: $A$ Decade of Progress. Soc. Econ. Paleontol. Mineral., Spec. Publ., 32:355-394.

Verbeek, J. W., 1977. Calcareous nannoplankton biostratigraphy of Middle and Upper Cretaceous deposits in Tunisia, Southern Spain and France. Utrecht Micropaleontol. Bull., 16:1-157.

Wiley, E. O., 1978. The evolutionary species concept reconsidered. Syst. Zool., 27:17-26.

Wind, F. H., 1975. Tetralithus copulatus Deflandre (Coccolithophyceae) from the Indian Ocean: A possible paleoecological indicator. Antarct. J.U.S., 10:265-268.

1978. Western North Atlantic Upper Jurassic calcareous nannofossil biostratigraphy. In Benson, W. E., Sheridan, R. E., et al., Init. Repts. DSDP, 44: Washington (U.S. Govt. Printing Office), 761-733.

1979a. Late Campanian and Maestrichtian calcareous nannoplankton biogeography and high-latitude biostratigraphy $[\mathrm{Ph}$. D. dissert]. Florida State University, Tallahassee.

1979b. Maestrichtian-Campanian nannofloral provinces of the southern Atlantic and Indian oceans. In Talwani, M., Hay, W. W., and Ryan, W. B. F. (Eds.), Deep Drilling Results in the Atlantic Ocean: Continental Margins and Paleoenvironment. Am. Geophys. Union, Maurice Ewing Ser., 3:123-137.

, in press. The genus Nephrolithus Gorka, 1957 (Coccolithophoridae). J. Paleontol.

Wind, F. H., and Wise, S. W., 1978. Mesozoic holococcoliths. Geology, 6:140-142.

Wise, S. W., 1973. Calcareous nannofossils from cores recovered during Leg 18, Deep Sea Drilling Project: Biostratigraphy and observations of diagenesis. In Kulm, L. D., von Huene, R., et al., Init. Repts. DSDP, 18: Washington (U.S. Govt. Printing Office), 569-615.

1977. Chalk formation: Early diagenesis. In Andersen, N. R., and Malahoff, A. (Eds.), The Fate of Fossil Fuel $\mathrm{CO}_{2}$ in the Oceans (Marine Science, Vol. 6). New York (Plenum), 717-739.
1981. Deep sea drilling in the Antarctic: Focus on late Miocene glaciation and applications of smear-slide biostratigraphy. In Warme, J. E., Douglas, R. G., and Winterer, E. L. (Eds.), The Deep Sea Drilling Project: A Decade of Progress. Soc. Econ. Paleontol. Mineral., Spec. Publ., 32:471-487.

Wise, S. W., Ciesielski, P. F., MacKenzie, D. T., Wind, F. H., Busen, K. E., et al., 1982. Paleontologic and paleoenvironmental synthesis for the southwest Atlantic Ocean basin based on Jurassic to Holocene faunas and floras from the Falkland Plateau. In Craddock, C. (Ed.), Antarctic Geoscience: Madison (Univ. of Wisconsin Press), pp. 155-163.

Wise, S. W., and Constans, R. E., 1976. Mid-Eocene planktonic correlations: northern Italy-Jamaica, W. I. Trans. Gulf Coast Assoc. Geol. Soc., 26:144-155.

Wise, S. W., and Kelts, K. R., 1972. Inferred diagenetic history of a weakly silicified deep sea chalk. Trans. Gulf Coast Assoc. Geol. Soc., 22:177-203.

Wise, S. W., and Wind, F. H., 1977. Mesozoic and Cenozoic calcareous nannofossils recovered by DSDP Leg 36 drilling on the Falkland Plateau, Southwest Atlantic sector of the Southern Ocean. In Barker, P. F., Dalziel, I. W. D., et al., Init. Repts. DSDP, 36: Washington (U.S. Govt. Printing Office), 269-492.

\section{APPENDIX A \\ Calcareous Nannofossils Considered in This Chapter}

\section{A. In Alphabetical Order of Species Epithets}

\section{Cenozoic}

Cyclicargolithus abisectus (Müller) Wise, 1973

Reticulofenestra alabamensis Roth, 1970

Chiasmolithus altus Bukry and Percival, 1971

Discoaster barbadiensis Tan Sin Hok, 1927

D. sp. cf. D. bifax Bukry, 1971

Zygrhablithus bijugatus (Deflandre) Deflandre, 1959

Discoaster binodosus Martini, 1958

Reticulofenestra bisecta bisecta (Hay, Mohler, and Wade) Roth, 1970

$R$. bisecta (Hay, Mohler, and Wade) Roth ssp. filewiczii Wise and Wiegand, n. ssp.

Discoaster brouweri Tan Sin Hok, 1927

Helicosphaera carteri (Wallich) Kamptner, 1954

Reticulofenestra coenura (Reinhardt) Roth, 1970

Lapideacassis cornuta Wind and Wise in Wise and Wind, 1977

Reticulofenestra daviesii (Haq) Haq, 1971

Discoaster deflandrei Bramlette and Riedel, 1954

Campylosphaera dela (Bramlette and Sullivan) Hay and Mohler, 1967

Reticulofenestra sp. cf. R. dictyoda (Deflandre and Fert) Stradner, 1968

Discoaster distinctus Martini, 1958

Neococcolithes dubius (Deflandre) Black, 1967

Coccolithus eopelagicus Gartner and Smith, 1967

Chiasmolithus expansus (Bramlette and Sullivan) Gartner, 1970

Clausicoccus fenestratus (Deflandre and Fert) Prins, 1979

Cyclicargolithus floridanus (Roth and Hay) Bukry, 1971

Coccolithus formosus (Kamptner) Wise, 1973

Sphenolithus furcatolithoides Locker, 1967

Chiasmolithus grandis (Bramlette and Riedel) Gartner, 1970

Thoracosphaera heimi (Lohmann) Kamptner, 1954

Reticulofenestra hesslandii (Haq) Roth, 1970

$R$. sp. cf. R. hesslandii (small) (Haq) Roth, 1970

$R$. hillae Bukry and Percival, 1971

Emiliania huxleyi (Lohmann) Hay and Mohler in Hay et al., 1967

Markalius inversus (Deflandre) Bramlette and Martini, 1964

Pseudotriquetrorhabdulus inversus (Bukry and Bramlette) Wise and Constans, n. comb.

Calcidiscus leptoporus (Murray and Blackman) Loeblich and Tappan, 1978

C. macintyrei (Bukry and Bramlette) Loeblich and Tappan, 1978

Coccolithus miopelagicus Bukry, 1971

Discoaster mirus Deflandre in Grasse, 1952

Sphenolithus moriformis (Brönnimann and Stradner) Bramlette and Wilcoxon, 1967

Coccolithus muiri Black, 1964 
Pontosphaera multipora (Kamptner) Roth, 1970

Discoaster multiradiatus Bramlette and Riedel, 1954

Chiasmolithus oamaruensis (Deflandre) Hay, Mohler, and Wade, 1966

Reticulofenestra oamaruensis (Deflandre) Stradner and Edwards, 1968

Pontosphaera obliquipons (Deflandre) Romein, 1979

Reticulofenestra onusta (Perch-Nielsen) Wise, n. comb.

Coccolithus pelagicus (Wallich) Schiller, 1930

Reticulofenestra perplexa (Burns) Wise, $\mathrm{n}$. comb.

Pontosphaera plana (Bramlette and Sullivan) Haq, 1971

Coccolithus pliopelagicus Wise, 1973

Reticulofenestra pseudoumbilica (Gartner) Gartner ssp. gelida (Geitzenauer) Wise, n. stat.

Pontosphaera pulcheroides (Sullivan) Romein, 1979

Sphenolithus radians Deflandre, 1952

Isthmolithus recurvus Deflandre in Deflandre and Fert, 1954

Reticulofenestra reticulata (Gartner) Roth, 1973

Discoaster saipanensis Bramlette and Riedel, 1954

Reticulofenestra samodurovi (Hay, Mohler, and Wade) Bukry and Percival, 1971

Helicosphaera seminulum (Bramlette and Sullivan) Jafar and Martini, 1975

Chiasmolithus solitus (Bramlette and Sullivan) Locker var. inversus Wise and Wiegand, n. var.

Blackites spinosus (Deflandre and Fert) Hay and Towe, 1962

Discoaster surculus Martini and Bramlette, 1963

D. tani nodifer Bramlette and Riedel, 1954

D. tani tani Bramlette and Riedel, 1954

Coccolithus tenuiforatus (Clocchiatti and Jerković) Wise, n. comb.

Chiasmolithus titus Gartner, 1970

Reticulofenestra umbilica (Levin) Martini and Ritzkowski, 1968

Discoaster variabilis Martini and Bramlette, 1963

Mesozoic

Corollithion achylosum (Stover) Thierstein, 1971

Braarudosphaera africana Stradner, 1961

Axopodorhabdus albianus (Black) Wind and Wise, this volume

Hayesites albiensis Manivit, 1971

Ethmorhabdus anglicus Rood, Hay, and Barnard, 1971

Retacapsa angustiforata Black, 1971

Chiastozygus angustus (Stover) Wise, n. comb.

Rhagodiscus angustus (Stradner) Reinhardt, 1971

Reinhardtites anthophorus (Deflandre) Perch-Nielsen, 1968

Rhagodiscus asper (Stradner, 1963) Reinhardt, 1967

Corollithion asymmetricum (Rood, Hay, and Barnard) Grün and Zweili, 1980

Watznaueria barnesae (Black) Perch-Nielsen, 1968

Microrhabdulus belgicus Hay and Towe, 1963

Cretarhabdella bergenii Wise and Wiegand, $\mathrm{n} . \mathrm{sp}$.

Braarudosphaera bigelowii (Grün and Braarud) Deflandre, 1947

Stephanolithion bigoti Deflandre, 1939 (short lateral spines)

S. bigoti Deflandre, 1939 (long lateral spines)

Seribiscutum bijugum Filewicz, Wind, and Wise in Wise and Wind, 1977

Watznaueria biporta Bukry, 1969

W. britannica (Stradner) Reinhardt, 1964

Grantarhabdus camaratus (Bukry) Wise, n. comb.

Lithraphidites carniolensis Deflandre, 1963

Lucianorhabdus cayeuxi Deflandre, 1959

Zeugrhabdotus choffati Rood, Hay, and Barnard, 1973

Gartnerago confossus (Noël) Noël, 1972

$G$. sp. cf. G. confossus (Noël) Noël, 1972

Cretarhabdus conicus Bramlette and Martini, 1964

Biscutum constans (Gorka) Black, 1959

Petrarhabdus copulatus (Deflandre) Wind and Wise, n. gen. n. comb.

Grantarhabdus coronadventis (Reinhardt) Grun in Grün and Allemann, 1975

G. sp. cf. G. coronadventis (Reinhardt) Grün in Grün and Allemann, 1975

Biscutum coronum Wind and Wise in Wise and Wind, 1977

Gartnerago costatum (Gartner) Bukry, 1969

Prediscosphaera cretacea (Arkhangelsky) Gartner, 1968

Arkhangelskiella cribrata (Gazdzicka) Wise, n. comb.
Hexapodorhabdus cuvillieri Noël, 1965

Axopodorhabdus cylindratus (Noël) Wind and Wise, 1977

Tetrapodorhabdus decorus (Deflandre and Fert) Wind and Wise in Wise and Wind, 1977

Micula decussata concavata (Stradner) Bukry, 1969

M. decussata decussata Vekshina, 1959

Corollithion delftensis (Stradner and Adamiker) Wise, n. comb.

Broinsonia dentata Bukry, 1969

Axopodorhabdus dietzmanni (Reinhardt) Wind and Wise, this volume

Zygodiscus diplogrammus (Deflandre and Fert) Gartner, 1968

Biscutum dissimilis Wind and Wise in Wise and Wind, 1977

Palaeopontosphaera dubia Noël, 1965

Thiersteinia ecclesiastica Wise and Watkins, n. gen., n. sp.

Cribrosphaera ehrenbergi (Arkhangelsky) Deflandre, 1952

Reinhardtites elegans (Gartner) Wise, n. comb.

Nannoconus elongatus Brönnimann, 1955

Parhabdolithus embergeri (Noël) Stradner, 1963

Zeugrhabdotus erectus (Deflandre) Reinhardt, 1965

Palaeopontosphaera erismata Wind and Wise, 1977

P. sp. cf. P. erismata Wind and Wise, 1977

Polypodorhabdus escaigi Noël, 1965

Corollithion escovillensis (Rood and Barnard), Wise, n. comb.

Eiffellithus eximius (Stover) Perch-Nielsen, 1968

Sollasites falklandensis Filewicz, Wind, and Wise, 1977

Percivalia fenestrata (Worsley) Wise, n. comb.

Zeugrhabdotus fissus Grün and Zweili, 1980

Lithastrinus floralis Stradner, 1962

Scapholithus fossilis Deflandre, 1954

Corollithion fragilis (Rood and Barnard) Wind and Wise in Wise and Wind, 1977

Marthasterites furcatus (Deflandre and Fert) Deflandre, 1959

Tranolithus gabalus Stover, 1966

Ethmorhabdus gallicus Noël, 1965

Chiastozygus garrisonii Bukry 1969

Corollithion geometricum (Gorka) Manivit, 1971

Lapideacassis glans Black, 1971

Prediscosphaera grandis Perch-Nielsen, 1979

Podorhabdus grassei Noël emend. Wind and Wise in Wise and Wind, 1977

Lithastrinus grillii Stradner, 1962

Biscutum hattneri Wise, $\mathrm{n}$, sp.

Corollithion helotatus Wind and Wise in Wise and Wind, 1977

Stephanolithion hexum Rood and Barnard, 1972

Sollasites horticus (Stradner, Adamiker, and Maresch) Black, 1968

Micrantholithus hoschulzi (Reinhardt) Thierstein, 1971

Bidiscus ignotus (Gorka) Lauer in Grün, et al., 1972

Parhabdolithus infinitus (Worsley) Thierstein, 1974

Stephanolithion laffittei Noël, 1957

Cretarhabdella lateralis Black, 1971

Cretarhabdus loriei Gartner, 1968

Polypodorhabdus madingleyensis Black, 1968

Kamptnerius magnificus Deflandre, 1959

Cyclagelosphaera margereli Noël, 1965

Lapideacassis mariae Black emend. Wind and Wise in Wise and Wind, 1977

Nannoconus multicadus Deflandre and Deflandre, 1960

Zeugrhabdotus noeli Rood, Hay, and Barnard, 1971

Flabellites oblongus (Bukry) Crux, 1982

Calculites obscurus (Deflandre) Prins and Sissingh in Sissingh, 1977

Ahmuellerella octoradiata (Gorka) Reinhardt, 1970

Tranolithus orionatus Stover, 1966

Calculites ovalis (Stradner) Prins and Sisingh in Sissingh, 1977

Watznaueria ovata Bukry, 1969

Broinsonia ssp. aff. B. parca constricta Hattner, Wind, and Wise, 1980

$B$. parca expansa Wise and Watkins, n. ssp.

Broinsonia parca parca (Stradner) Bukry, 1969

Repagulum parvidentatum (Deflandre and Fert) Forchheimer, 1972

Corollithion pauciramosus (Black) Wise, $\mathrm{n}$. comb.

Manivitella pemmatoidea (Deflandre ex Manivit) Thierstein, 1971

Seribiscutum pinnatum (Black) Wise, n. comb.

$S$. primitivum (Thierstein) Filewicz, Wind, and Wise in Wind and Wise, this volume

Schizosphaerella punctulata Deflandre and Dangeard, 1938 
Vekshinella quadriarculla (Noël) Rood, Hay, and Barnard, 1971 Octocyclus reinhardtii (Bukry) Wind and Wise in Wise and Wind, 1977 Watznaueria reinhardtii Rood, Hay, and Barnard, 1971

Corollithion rhombicum (Stradner and Adamiker) Bukry, 1969

Seribiscutum salebrosum (Black) Wise, n. comb.

Zeugrhabdotus sallium (Noël) Rood, Hay, and Barnard, 1971

Acuturris scotus (Risatti) Wind and Wise, 1977

Corollithion scutulatum (Medd) Grün and Zweili, 1980

C. senarius Wind and Wise, 1977

Zygodiscus sp. cf. Z. sigmoides Bramlette and Sullivan, 1971

Corollithion signum Stradner, 1963

C. silvaradion Filewicz, Wind, and Wise in Wise and Wind, 1977

Prediscosphaera spinosa (Bramlette and Martini) Gartner, 1968

Rhagodiscus splendens (Deflandre) Verbeek, 1977

Vekshinella stradneri Rood, Hay, and Barnard, 1971

Crucicribrum striatum constansii Wise and Parker, n. ssp.

C. striatum striatum (Stradner) Wise, n. comb.

Watznaueria supracretacea (Reinhardt) Wind and Wise in Wise and Wind, 1977

Cretarhabdus surirellus (Deflandre and Fert) Reinhardt emend. Thierstein, 1971

Chiastozygus synquadriperforatus Bukry, 1969

Eiffellithus trabeculatus (Gorka) Reinhardt and Gorka, 1967

E. sp. cf. E. trabeculatus (Gorka) Reinhardt and Gorka, 1967

Nannoconus truitti Brönnimann, 1955

Eiffellithus turriseiffeli (Deflandre and Fert) Reinhardt, 1965

Turbodiscus sp. cf. T. verenae Thierstein, 1973

\section{B. In Alphabetical Order of Generic Epithets}

Cenozoic

Blackites spinosus (Deflandre and Fert) Hay and Towe, 1962

Calcidiscus leptoporus (Murray and Blackman) Loeblich and Tappan, 1978

C. macintyrei (Bukry and Bramlette) Loeblich and Tappan, 1978

Campylosphaera dela (Bramlette and Sullivan) Hay and Mohler, 1967

Chiasmolithus altus Bukry and Percival, 1971

C. expansus (Bramlette and Sullivan) Gartner, 1970

C. grandis (Bramlette and Riedel) Gartner, 1970

C. oamaruensis (Deflandre) Hay, Mohler, and Wade, 1966

C. solitus (Bramlette and Sullivan) Locker var. inversus Wise and Wiegand, n. var.

C. titus Gartner, 1970

Clausicoccus fenestratus (Deflandre and Fert) Prins, 1979

Coccolithus eopelagicus Gartner and Smith, 1967

C. formosus (Kamptner) Wise, 1973

C. miopelagicus Bukry, 1971

C. muiri Black, 1964

C. pelagicus (Wallich) Schiller, 1930

C. pliopelagicus Wise, 1973

C. tenuiforatus (Clocchiatti and Jerković) Wise, n. comb.

Cyclicargolithus abisectus (Müller) Wise, 1973

C. floridanus (Roth and Hay) Bukry, 1971

Discoaster barbadiensis Tan Sin Hok, 1927

D. sp. cf. D. bifax Bukry, 1971

D. binodosus Martini, 1958

D. brouweri Tan Sin Hok, 1927

D. deflandrei Bramlette and Riedel, 1954

D. distinctus Martini, 1958

D. mirus Deflandre in Grasse, 1952

D. multiradiatus Bramlette and Riedel, 1954

D. saipanensis Bramlette and Riedel, 1954

D. surculus Martini and Bramlette, 1963

D. tani nodifer Bramlette and Riedel, 1954

D. tani tani Bramlette and Riedel, 1954

D. variabilis Martini and Bramlette, 1963

Emiliania huxleyi (Lohmann) Hay and Mohler in Hay et al., 1967

Helicosphaera carteri (Wallich) Kamptner, 1954

H. seminulum (Bramlette and Sullivan) Jafar and Martini, 1975

Isthmolithus recurvus Deflandre in Deflandre and Fert, 1954

Lapideacassis cornuta Wind and Wise, 1977

Markalius inversus (Deflandre) Bramlette and Martini, 1964

Neococcolithes dubius (Deflandre) Black, 1967
Pontosphaera multipora (Kamptner) Roth, 1970

P. obliquipons (Deflandre) Romein, 1979

P. plana (Bramlette and Sullivan) Haq, 1971.

P. pulcheroides (Sullivan) Romein, 1979

Pseudotriquetrorhabdulus inversus (Bukry and Bramlette) Wise and Constans, n. comb.

Reticulofenestra alabamensis Roth, 1970

$R$. bisecta bisecta (Hay, Mohler, and Wade) Roth, 1970

$R$. bisecta (Hay, Mohler, and Wade) Roth ssp. filewiczii Wise and Wiegand, n. ssp.

$R$. coenura (Reinhardt) Roth, 1970

$R$. daviesii (Haq) Haq, 1971

$R$. sp. cf. $R$. dictyoda (Deflandre and Fert) Stradner, 1968

$R$. hesslandii (Haq) Roth, 1970

$R$. sp. cf. $R$. hesslandii (small) (Haq) Roth, 1970

$R$. hillae Bukry and Percival, 1971

$R$. oamaruensis (Deflandre) Stradner and Edwards, 1968

$R$. onusta (Perch-Nielsen) Wise, n. comb.

$R$. perplexa (Burns) Wise, n. comb.

R. pseudoumbilica (Gartner) Gartner ssp. gelida (Geitzenauer) Wise, n. stat.

R. reticulata (Gartner) Roth, 1973

R. samodurovi (Hay, Mohler, and Wade) Bukry and Percival, 1971

R. umbilica (Levin) Martini and Ritzkowski, 1968

Sphenolithus furcatolithoides Locker, 1967

$S$. moriformis (Brönimann and Stradner) Bramlette and Wilcoxon, 1967

S. radians Deflandre, 1952

Thoracosphaera heimi (Lohmann) Kamptner, 1954

Zygrhablithus bijugatus (Deflandre) Deflandre, 1959

Mesozoic

Acuturris scotus (Risatti) Wind and Wise, 1977

Ahmuellerella octoradiata (Gorka) Reinhardt, 1970

Arkhangelskiella cribrata (Gazdzicka) Wise, n. comb.

Axopodorhabdus albianus (Black) Wind and Wise, this volume

A. cylindratus (Noël) Wind and Wise in Wise and Wind, 1977

A. dietzmanni (Reinhardt) Wind and Wise, this volume

Bidiscus ignotus (Gorka) Lauer in Grün et al., 1972

Biscutum constans (Gorka) Black, 1959

B. coronum Wind and Wise in Wise and Wind 1977

$B$. dissimilis Wind and Wise in Wise and Wind, 1977

$B$. hattneri Wise, n. sp.

Braarudosphaera africana Stradner, 1961

B. bigelowii (Grün and Braarud) Deflandre, 1947

Broinsonia dentata Bukry, 1969

B. ssp. aff. B. parca constricta Hattner, Wind, and Wise, 1980

$B$. parca expansa, Wise and Watkins, n. ssp.

B. parca parca (Stradner) Bukry, 1969

Calculites obscurus (Deflandre) Prins and Sissingh in Sissingh, 1977

C. ovalis (Stradner) Prins and Sissingh in Sissingh, 1977

Chiastozygus angustus (Stover) Wise, n. comb.

C. garrisonii Bukry, 1969

C. synquadriperforatus Bukry, 1969

Corollithion achylosum (Stover) Thierstein, 1971

C. asymmetricum (Rood, Hay, and Barnard) Grün and Zweili, 1980

C. delftensis (Stradner and Adamiker) Wise, n. comb.

C. escovillensis (Rood and Barnard), Wise, n. comb.

C. fragilis (Rood and Barnard) Wind and Wise in Wise and Wind, 1977

C. geometricum (Gorka) Manivit, 1971

C. helotatus Wind and Wise in Wise and Wind, 1977

C. pauciramosus (Black) Wise, $\mathrm{n}$. comb.

C. rhombicum (Stradner and Adamiker) Bukry, 1969

C. scutulatum (Medd) Grün and Zweili, 1980

C. senarius Wind and Wise in Wise and Wind, 1977

C. signum Stradner, 1963

C. silvaradion Filewicz, Wind, and Wise in Wise and Wind, 1977

Cretarhabdella bergenii Wise and Wiegand, $\mathrm{n}$. sp.

C. lateralis Black, 1971

Cretarhabdus conicus Bramlette and Martini, 1964

C. loriei Gartner, 1968

C. surirellus (Deflandre and Fert) Reinhardt emend. Thierstein, 1971

Cribrosphaera ehrenbergi (Arkhangelsky) Deflandre, 1952 
Crucicribrum striatum constansii Wise and Parker, n. ssp.

C. striatum striatum (Stradner) Wise, n. comb.

Cyclagelosphaera margereli Noël, 1965

Eiffellithus eximius (Stover) Perch-Nielsen, 1968

E. trabeculatus (Gorka) Reinhardt and Gorka, 1967

E. sp. cf. E. trabeculatus (Gorka) Reinhardt and Gorka, 1967

E. turriseiffeli (Deflandre and Fert) Reinhardt, 1965

Ethmorhabdus anglicus Rood, Hay, and Barnard, 1971

E. gallicus Noël, 1965

Flabellites oblongus (Bukry) Crux, 1982

Gartnerago confossus (Noël) Noël, 1972

G. sp. cf. G. confossus (Noël) Noël, 1972

G. costatum (Gartner) Bukry, 1969

Grantarhabdus camaratus (Bukry) Wise, n. comb.

G. coronadventis (Reinhardt) Grün in Grün and Allemann, 1975

G. sp. cf. G. coronadventis (Reinhardt) Grün in Grün and Allemann, 1975

Hayesites albiensis Manivit, 1971

Hexapodorhabdus cuvillieri Noël, 1965

Kamptnerius magnificus Deflandre, 1959

Lapideacassis glans Black, 1971

L. mariae Black emend. Wind and Wise in Wise and Wind, 1977

Lithastrinus floralis Stradner, 1962

L. grillii Stradner, 1962

Lithraphidites carniolensis Deflandre, 1963

Lucianorhabdus cayeuxii Deflandre, 1959

Manivitella pemmatoidea (Deflandre ex Manivit) Thierstein, 1971

Marthasterites furcatus (Deflandre and Fert) Deflandre, 1959

Micrantholithus hoschulzi (Reinhardt) Thierstein, 1971

Microrhabdulus belgicus Hay and Towe, 1963

Micula decussata concavata (Stradner) Bukry, 1969

M. decussata decussata Vekshina, 1959

Nannoconus elongatus Bronnimann, 1955

N. multicadus Deflandre and Deflandre, 1960

N. truitti Brönnimann, 1955

Octocyclus reinhardtii (Bukry) Wind and Wise, 1977

Palaeopontosphaera dubia Noël, 1965

P. erismata Wind and Wise, 1977

$P$. sp. cf. P. erismata Wind and Wise, 1977

Parhabdolithus embergeri (Noël) Stradner, 1963

P. infinitus (Worsley) Thierstein, 1974

Percivalia fenestrata (Worsley) Wise, n. comb.

Petrarhabdus copulatus (Deflandre) Wind and Wise, n. gen, n. comb.

Podorhabdus grassei Noel emend. Wind and Wise in Wise and Wind, 1977

Polypodorhabdus escaigi Noël, 1965

P. madingleyensis Black, 1968

Prediscosphaera cretacea (Arkhangelsky) Gartner, 1968

P. grandis Perch-Nielsen, 1979

P. spinosa (Bramlette and Martini) Gartner, 1968

Reinhardtites anthophorus (Deflandre) Perch-Nielsen, 1968

$R$. elegans (Gartner) Wise, n. comb.

Repagulum parvidentatum (Deflandre and Fert) Forchheimer, 1972

Retacapsa angustiforata Black, 1971

Rhagodiscus angustus (Stradner) Reinhardt, 1971

$R$. asper (Stradner) Reinhardt, 1967

R. splendens (Deflandre) Verbeek, 1977

Scapholithus fossilis Deflandre, 1954

Schizosphaerella punctulata Deflandre and Dangeard, 1938

Seribiscutum bijugum Filewicz, Wind, and Wise in Wise and Wind, 1977

S. pinnatum (Black) Wise, n. comb.

$S$. primitivum (Thierstein) Filewicz, Wind, and Wise in Wind and Wise, this volume

S. salebrosum (Black) Wise, n. comb.

Sollasites falklandensis Filewicz, Wind, and Wise in Wise and Wind, 1977

S. horticus (Stradner, Adamiker, and Maresch) Black, 1968

Stephanolithion bigoti Deflandre, 1939 (short lateral spines)

S. bigoti Deflandre, 1939 (long lateral spines)

S. hexum Rood and Barnard, 1972

S. laffittei Noel, 1957

Tetrapodorhabdus decorus (Deflandre and Fert) Wind and Wise in Wise and Wind, 1977
Thiersteinia ecclesiastica Wise and Watkins, n. gen., n. sp.

Tranolithus gabalus Stover, 1966

T. orionatus Stover, 1966

Turbodiscus sp. cf. T. verenae Thierstein, 1973

Vekshinella quadriarculla (Noël) Rood, Hay, and Barnard, 1971

V. stradneri Rood, Hay, and Barnard, 1971

Watznaueria barnesae (Black) Perch-Nielsen, 1968

W. biporta Bukry, 1969

W. britannica (Stradner) Reinhardt, 1964

W. ovata Bukry, 1969

W. reinhardtii Rood, Hay, and Barnard, 1971

W. supracretacea (Reinhardt) Wind and Wise in Wise and Wind, 1977

Zeugrhabdotus choffati Rood, Hay, and Barnard, 1973

Z. erectus (Deflandre) Reinhardt, 1965

Z. fissus Grün and Zweili, 1980

Z. noeli Rood, Hay, and Barnard, 1971

Z. sallium (Noel) Rood, Hay, and Barnard, 1971

Zygodiscus diplogrammus (Deflandre and Fert) Gartner, 1968

Z. sp. cf. Z sigmoides Bramlette and Sullivan, 1971

\section{APPENDIX B}

Austral Species Encountered in the Falkland Plateau Region, Legs 36 and $71^{1}$

\section{Cenozoic}

Chiasmolithus altus

C. bidens (Bramlette and Sullivan) Hay and Mohler, 1967

C. oamaruensis

C. solitus

Clausicoccus fenestratus

Coccolithus miopelagicus

C. pelagicus

C. pliopelagicus

Ellipsolithus distichus (Bramlette and Sullivan) Sullivan, 1964

Emiliania huxleyi

Fasciculithus involutus Bramlette and Sullivan, 1961

Heliolithus universus Wind and Wise, 1977

Hornibrookina australis Edwards and Perch-Nielsen, 1975

Isthmolithus recurvus

Neochiastozygus distentus (Bramlette and Sullivan) Perch-Nielsen, 1971

Neococcolithes dubius

N. protens (Bramlette and Sullivan) Hay and Mohler, 1967

Prinsius bisulcus (Stradner) Hay and Mohler, 1967

Reticulofenestra bisecta bisecta

$R$. bisecta filewiczii

$R$. daviesii

$R$. hesslandii

$R$. hillae

R. oamaruensis

$R$. onusta

R. perplexa

$R$. pseudoumbilica gelida

$R$. samodurovi

R. umbilica

Toweius eminens (Bramlette and Sullivan) Perch-Nielsen, 1971

Tribrachiatus orthostylus Shamrai, 1963

\section{Cretaceous}

Acuturris scotus

Ahmuellerella octoradiata

Arkhangelskiella cribrata

A. specillata Vekshina, 1959

Biscutum constans

B. coronum

B. dissimilis

B. hattneri

B. magnum Wind and Wise, 1977

Boletuvelum candens Wind and Wise, 1977

Braarudosphaera bigelowii

Broinsonia dentata

\footnotetext{
${ }^{1}$ Species encountered only during Leg 36 are distinguished by full citations.
} 
B. parca expansa

B. parca parca

Calculites obscurus

C. ovalis

Centosphaera barbatia Wind and Wise, 1977

Corollithion fragilis

C. silvaradion

Cretarhabdella bergenii

Cretarhabdus conicus

C. loriei

C. surirellus

Cribrosphaera ehrenbergi

Crucicribrum striatum constansii

Cyclagelosphaera margereli

Eiffellithus eximius

E. turriseiffeli

Gartnerago confossus

G. costatum

Grantarhabdus coronadventis

Heteromarginatus wallacei Bukry, 1969

Kamptnerius magnificus

Lapideacassis glans

L. mariae

Laguncula dorotheae Black, 1971

Lithastrinus floralis

L. grillii

Lithraphidites carniolensis

Lucianorhabdus cayeuxii

Micrantholithus hoschulzi

M. belgicus

Micula decussata

Misceomarginatus pleniporus Wind and Wise, 1977

Monomarginatus pectinatus Wind and Wise, 1977

M. quaternarius Wind and Wise, 1977

Nannoconus truitti
Octocyclus reinhardtii

Okkolithus australis Wind and Wise, 1977

Orastrum asarotum Wind and Wise, 1977

Nephrolithus frequens Gorka, 1957

$N$. corystus Wind, 1982

Parhabdolithus embergeri

Polypodorhabdus madingleyensis

Pharus simulacrum Wind and Wise, 1977

Prediscosphaera cretacea

$P$. grandis

P. spinosa

Reinhardtites elegans

Repagulum parvidentatum

Retacapsa angustiforata

Rhagodiscus asper

Seribiscutum bijugum

S. primitivum

S. salebrosum

Sollasites falklandensis

S. horticus

Stephanolithion laffittei

Tetrapodorhabdus decorus

Thiersteinia ecclesiastica

Tranolithus orionatus

Watznaueria barnesae

\section{Jurassic}

Not enough data are available to make a strong distinction between Austral and Tethyan Jurassic species of the Falkland Plateau assemblages. The following species, however, stand out as characteristic high-latitude forms.

Corollithion delftensis

C. helotatus Wind and Wise, 1977

C. senarius

Stephanolithion bigoti (short lateral spines)

\section{NOTE ON THE PLATES}

All illustrations on the plates are scanning electron micrographs unless noted otherwise in the captions. The abbreviations $\mathrm{P}, \mathrm{D}$, and $\mathrm{L}$ denote proximal, distal, and lateral views respectively. The abbreviations $\mathrm{Pol}, \mathrm{Ph}$, and $\operatorname{Tr}$ denote cross-polarized, phase contrast, and transmitted light. 

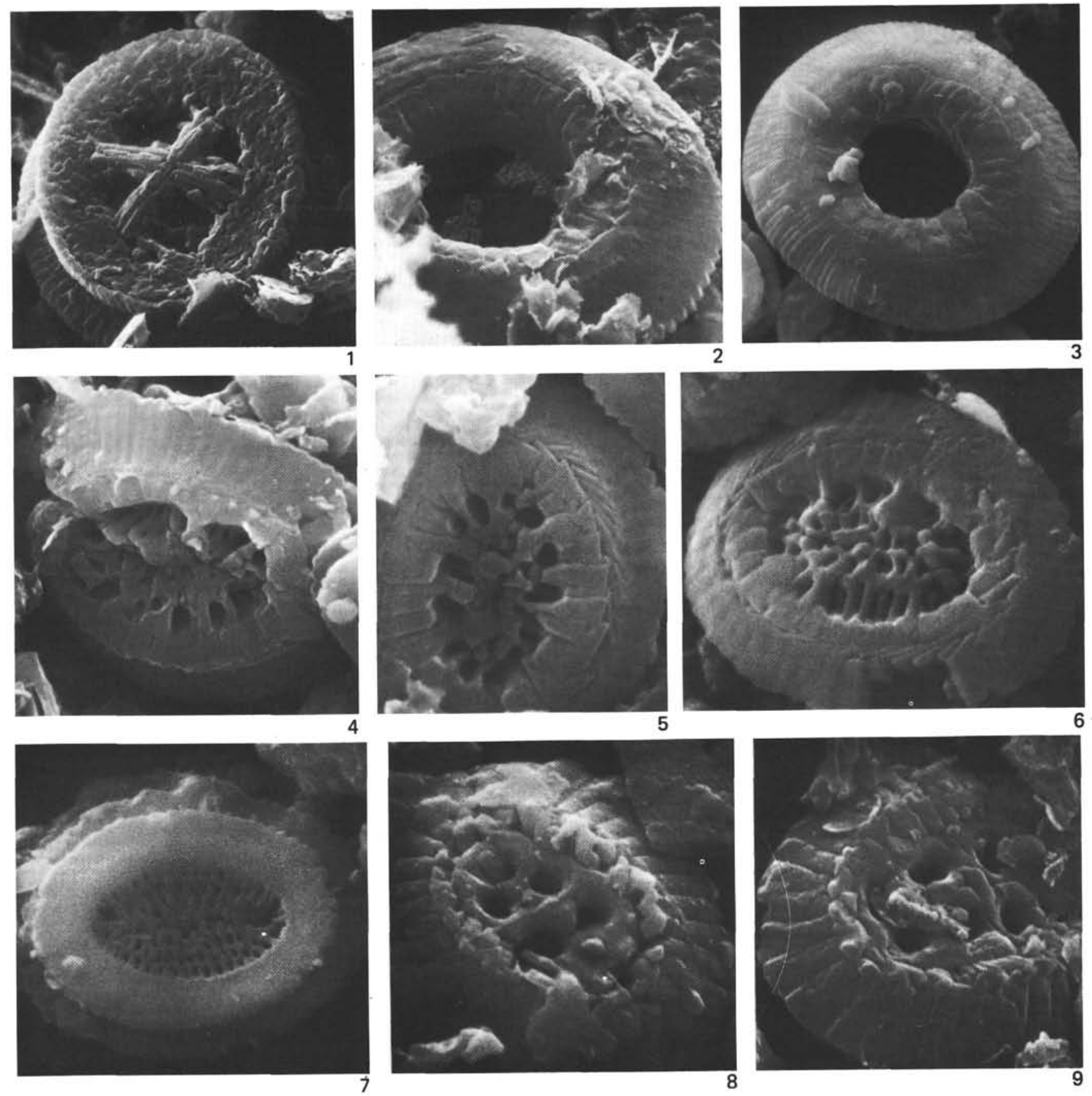

Plate 1. Oligocene. 1. Chiasmolithus altus Bukry and Percival, D, $\times 5000$, Sample $511-10-1,10 \mathrm{~cm}$. 2-3. Reticulofenestra umbilica (Levin) Martini and Ritzkowski, D (2) $\times 8000$, Sample $511-10-1,10 \mathrm{~cm},(3) \times 3500$, Sample 513A-30-2, $50 \mathrm{~cm}$. 4-6. Reticulofenestra daviesii (Haq) Haq, D, Sample $511-10-1,10 \mathrm{~cm},(4) \times 7000,(5) \times 15,5000,(6) \times 13,5000$. 7. Reticulofenestra coenura (Reinhardt) Roth, P, $\times 11,5000$, Sample $511-4-3,13 \mathrm{~cm}$. 8-9. Clausicoccus fenestratus (Deflandre) Prins, D, (8) $\times 14,5000$, Sample $511-4-3,13 \mathrm{~cm},(9) \times 15,000$, Sample $511-10-1$, $10 \mathrm{~cm}$. 

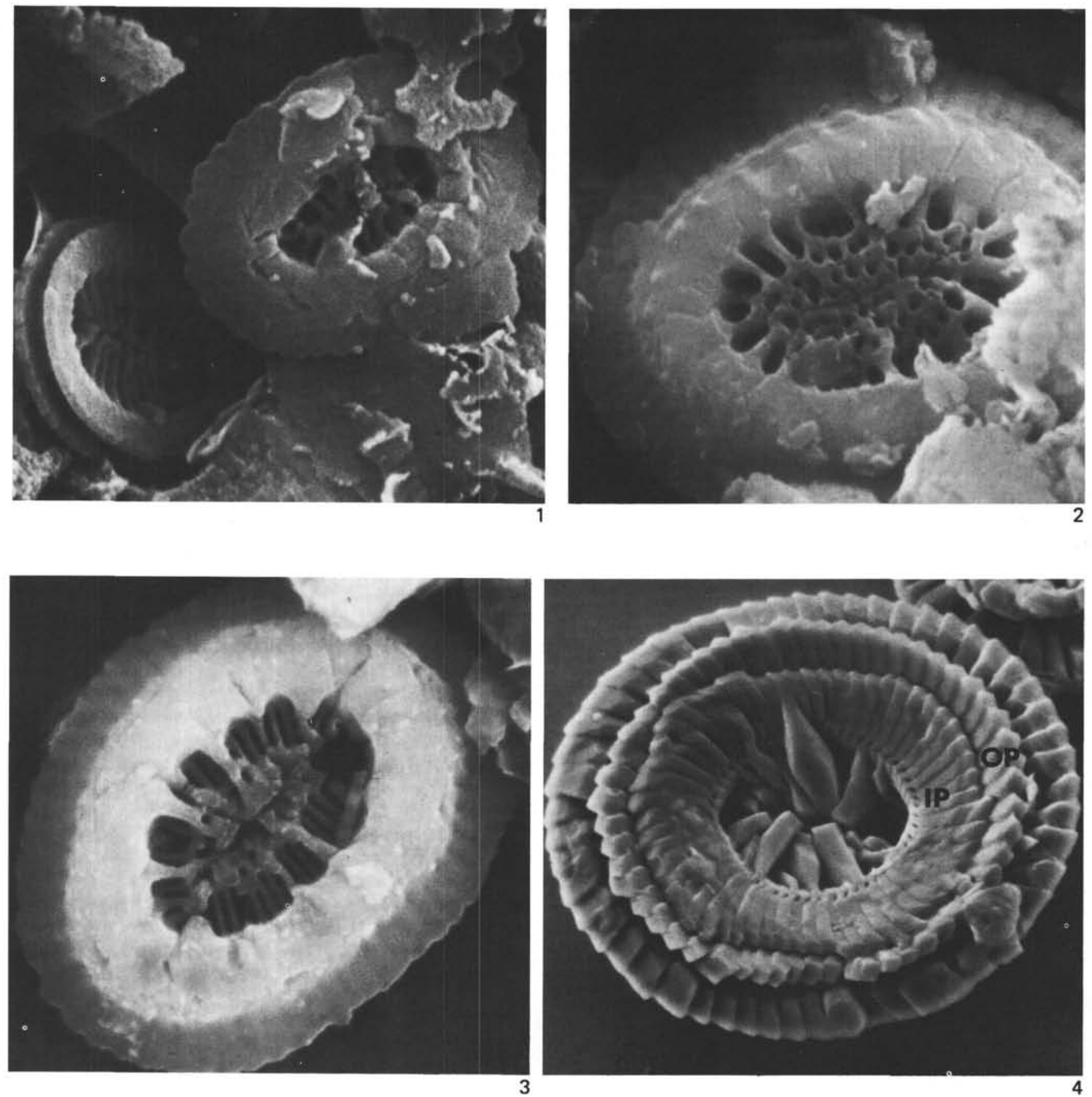

Plate 2. Oligocene; Eocene. 1. Reticulofenestra alabamensis Roth (upper right of fig., D); Reticulofenestra sp. (lower left of fig., P), $\times 17,000$, Sample 511-10-1, $10 \mathrm{~cm}$. 2-3. Reticulofenestra daviesii (Haq) Haq, D (2) $\times 14,5000$, Oligocene Sample $511-10-1,10 \mathrm{~cm},(3) \times 14,000$, Eocene Sample 511-18-2, $24 \mathrm{~cm}$. 4. Coccolithus muiri Black, P, $\times 9000$, Eocene Sample 245-8-1, $55 \mathrm{~cm}$. (From MacKenzie and Wise, this volume, Pl. 7, Fig. 4. IP = inner proximal cycle; $\mathrm{OP}=$ outer proximal cycle.) 

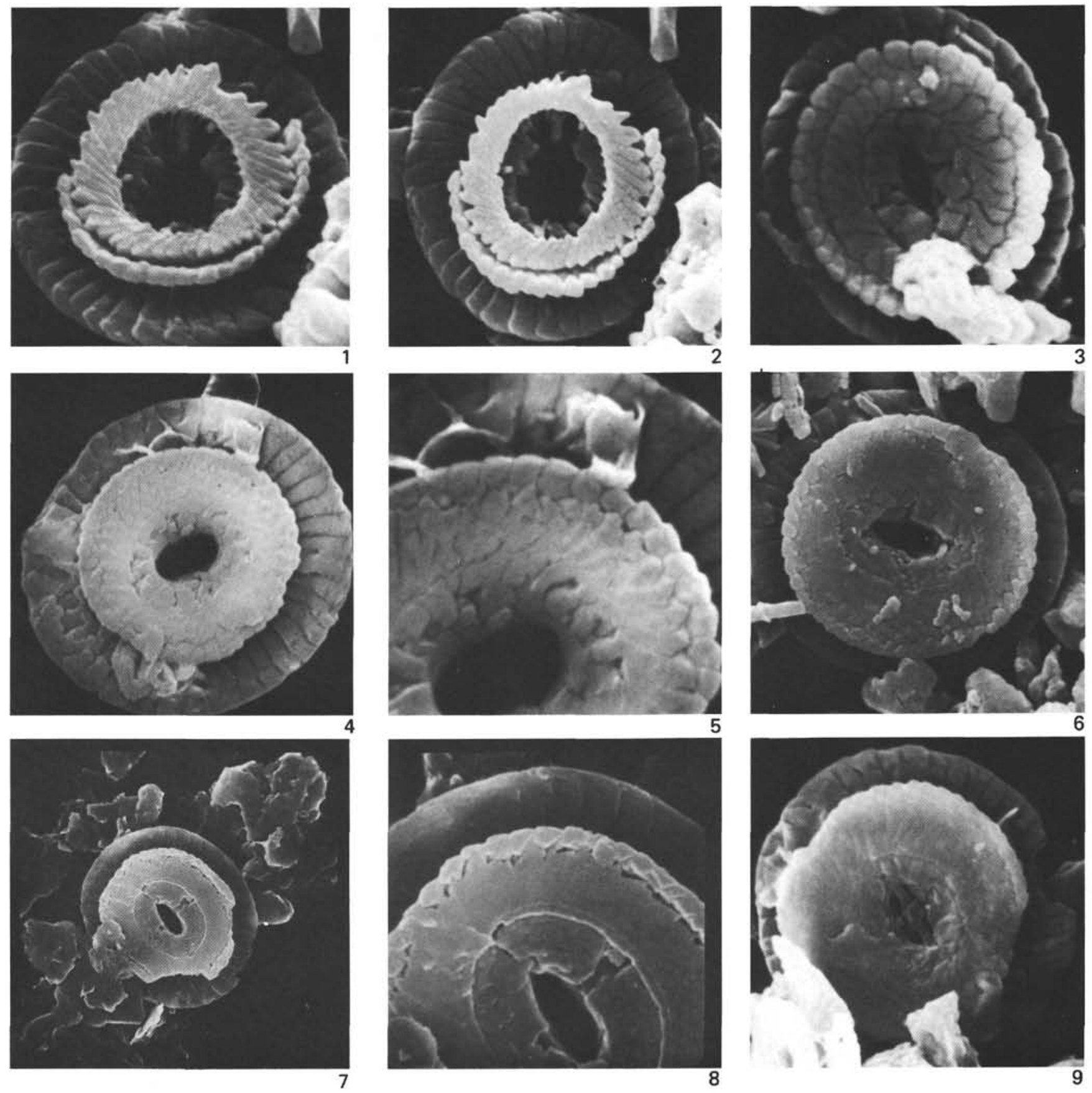

Plate 3. Miocene. 1-8. Coccolithus pelagicus (Wallich) Schiller, $\mathrm{P},(1-2)$ Sample $29 \mathrm{~B}-5-3,118 \mathrm{~cm}(1, \times 6400 ; 2 \times 5700)(3) \times 9500$, Sample $29 \mathrm{~B}-$ $5-3,118 \mathrm{~cm},(4-5)$ Sample Bo 187 (Trinidad) $(4, \times 5600 ; 5$, detail of proximal shield, $\times 11,000),(6) \times 5700$, Sample 29B-5-3, 118 cm, (7-8) Sample RD 784 (Venezuela) $(7, \times 4500 ; 8$, detail of proximal shield, $\times 13,000)$. 9. Coccolithus tenuiforatus (Clocchiatti and Jerković) Wise, n. comb., P, $\times 5000$, Sample Bo 187 (Trinidad). 

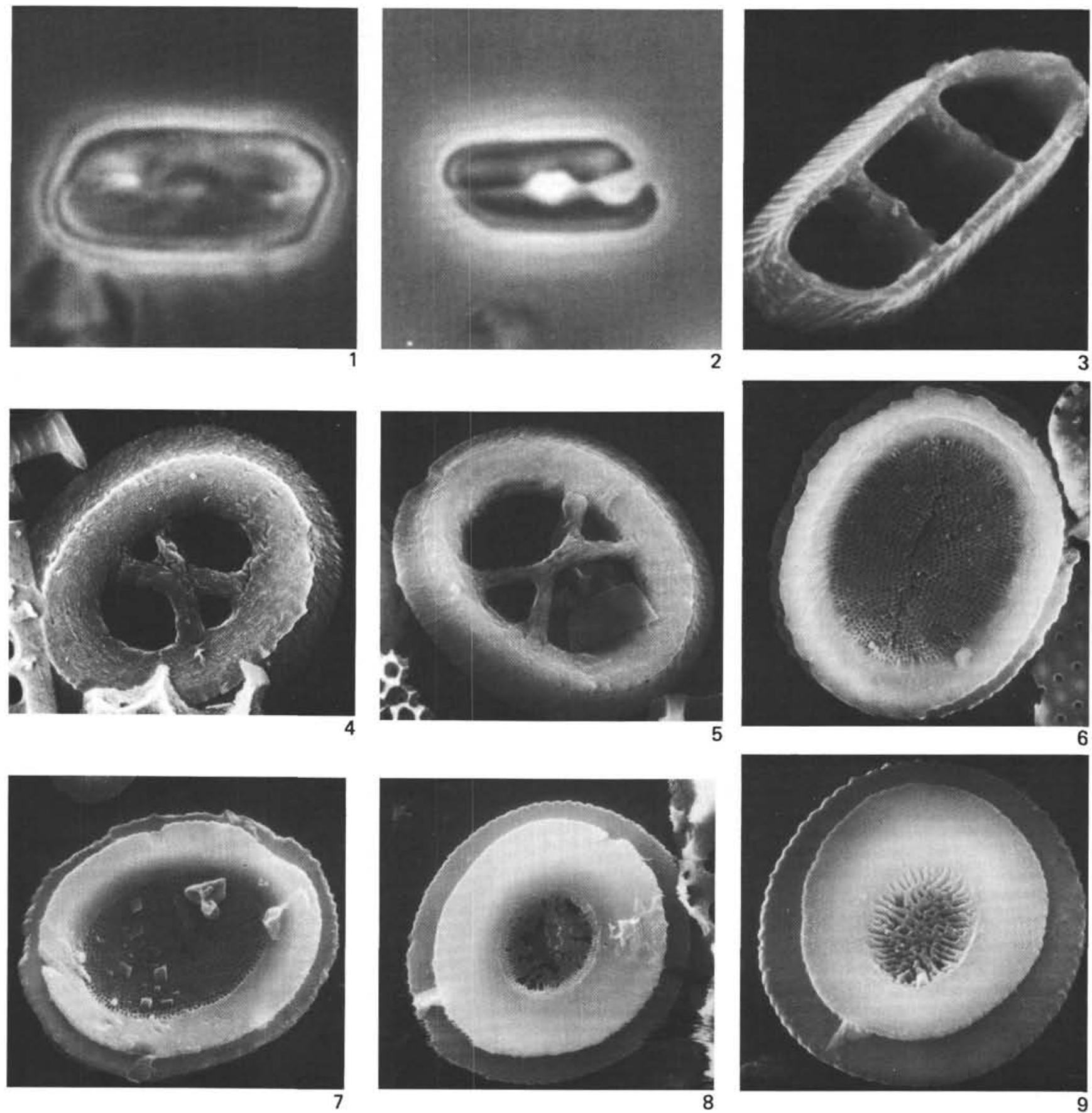

Plate 4. Lower Oligocene, upper Eocene. 1-3. Isthmolithus recurvus Deflandre, (1-2) $\mathrm{Ph}, \times 7000$, Oligocene Sample 513A-31-1, 27 cm, (3) $\times 11,000$, Eocene Sample 511-18-2, $24 \mathrm{~cm} . \quad 4-5$. Chiasmolithus oamaruensis (Deflandre) Hay, Mohler, and Wade, D, $\times 4400$, Eocene Sample 511-18-2, $24 \mathrm{~cm}$. 6-7. Reticulofenestra oamaruensis (Deflandre) Stradner and Edwards, P, Eocene Sample 511-18-2, 24 cm, (6) $\times 4200,(7)$ $\times 5000$. 8. Reticulofenestra umbilica (Levin) Martini and Ritzkowski, P, $\times 3500$, Eocene Sample 511-18-2, $24 \mathrm{~cm}$. 9. Reticulofenestra sp. cf. $R$. dictyoda (Deflandre and Fert) Stradner, $\times 6800$, Eocene Sample 511-18-2, $24 \mathrm{~cm}$. 

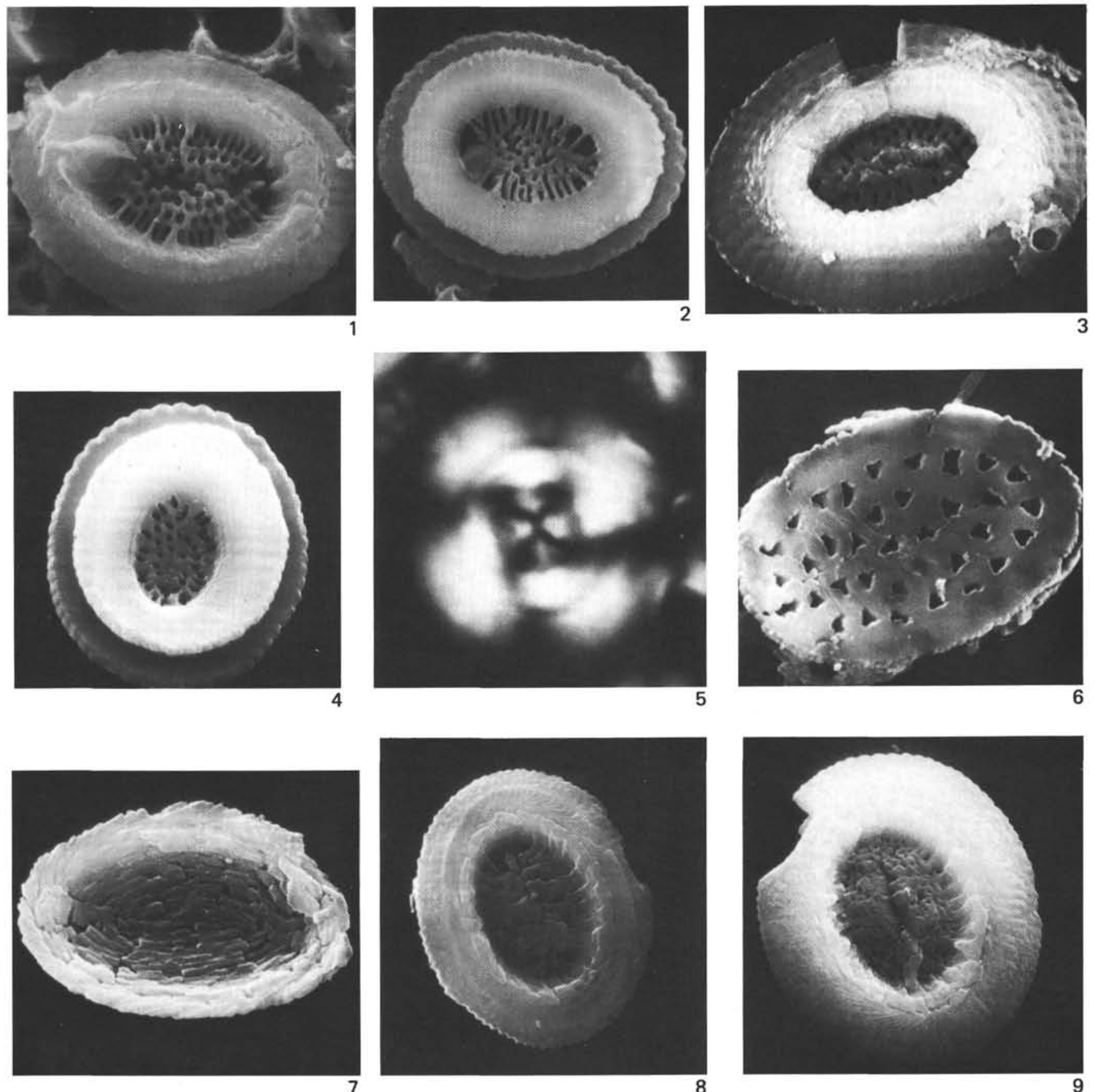

Plate 5. Upper, middle Eocene. 1-2, 4. Reticulofenestra daviesii (Haq) Haq, Sample 511-18-2, $24 \mathrm{~cm},(1) \mathrm{D}, \times 9000,(2) \mathrm{D}, \times 9000,(4) \mathrm{P}$, $\times 85000$. 3. Reticulofenestra bisecta filewiczii Wise and Wiegand, n. ssp., paratype, D, $\times 10,000$, Sample 511-18-2, $24 \mathrm{~cm}$. 5 . Reticulofenestra reticulata (Gartner), Roth, Pol, $\times 5000$, Sample 511-18-1, $24 \mathrm{~cm}$. 6. Pontosphaera multipora (Kamptner) Roth, P, $\times 7500$, Sample 511-18-2, $24 \mathrm{~cm}$. 7. Pontosphaera plana (Bramlette and Sullivan) Haq, $\times 4400$, Sample $512-18-3,11 \mathrm{~cm} .8-9$. Reticulofenestra onusta (Perch-Nielsen) Wise, n. comb., D, (8) $\times 4200$, Sample 512-18-3, $11 \mathrm{~cm},(9) \times 4700$, Sample 512-7-3, $66 \mathrm{~cm}$. 

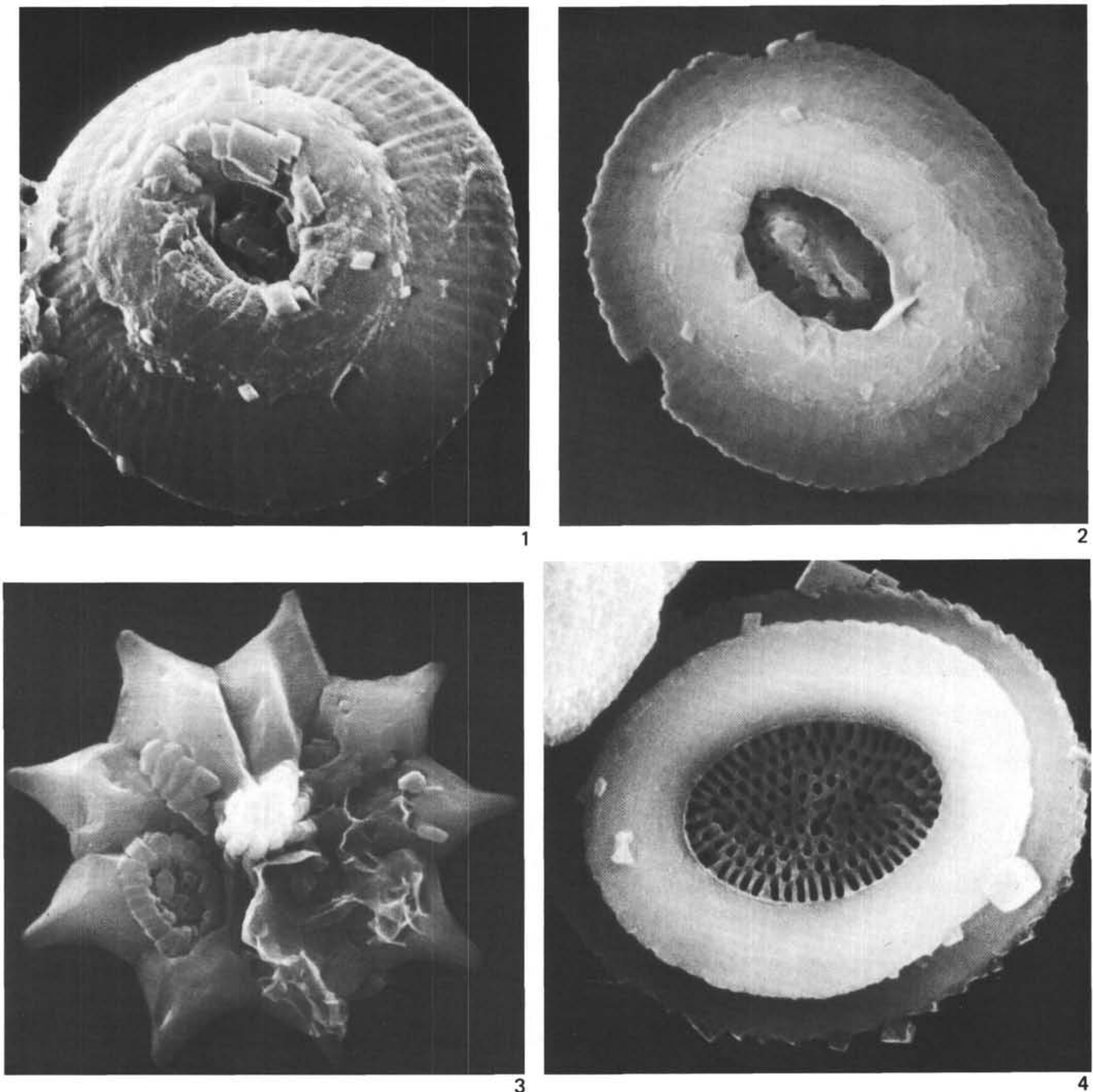

Plate 6. Upper, middle Eocene. 1-2. Reticulofenestra bisecta filewiczii Wise and Wiegand, n. ssp., D, Sample 511-18-2, 24 cm (1) paratype, $\times 8000$, (2) holotype, $\times 10,500$. 3. Discoaster barbadiensis Tan Sin Hok, $\times 7500$, Sample $512-18-3,11 \mathrm{~cm}$. 4. Reticulofenestra coenura (Reinhardt) Roth, P, $\times 6000$, Sample $511-18-2,24 \mathrm{~cm}$. 

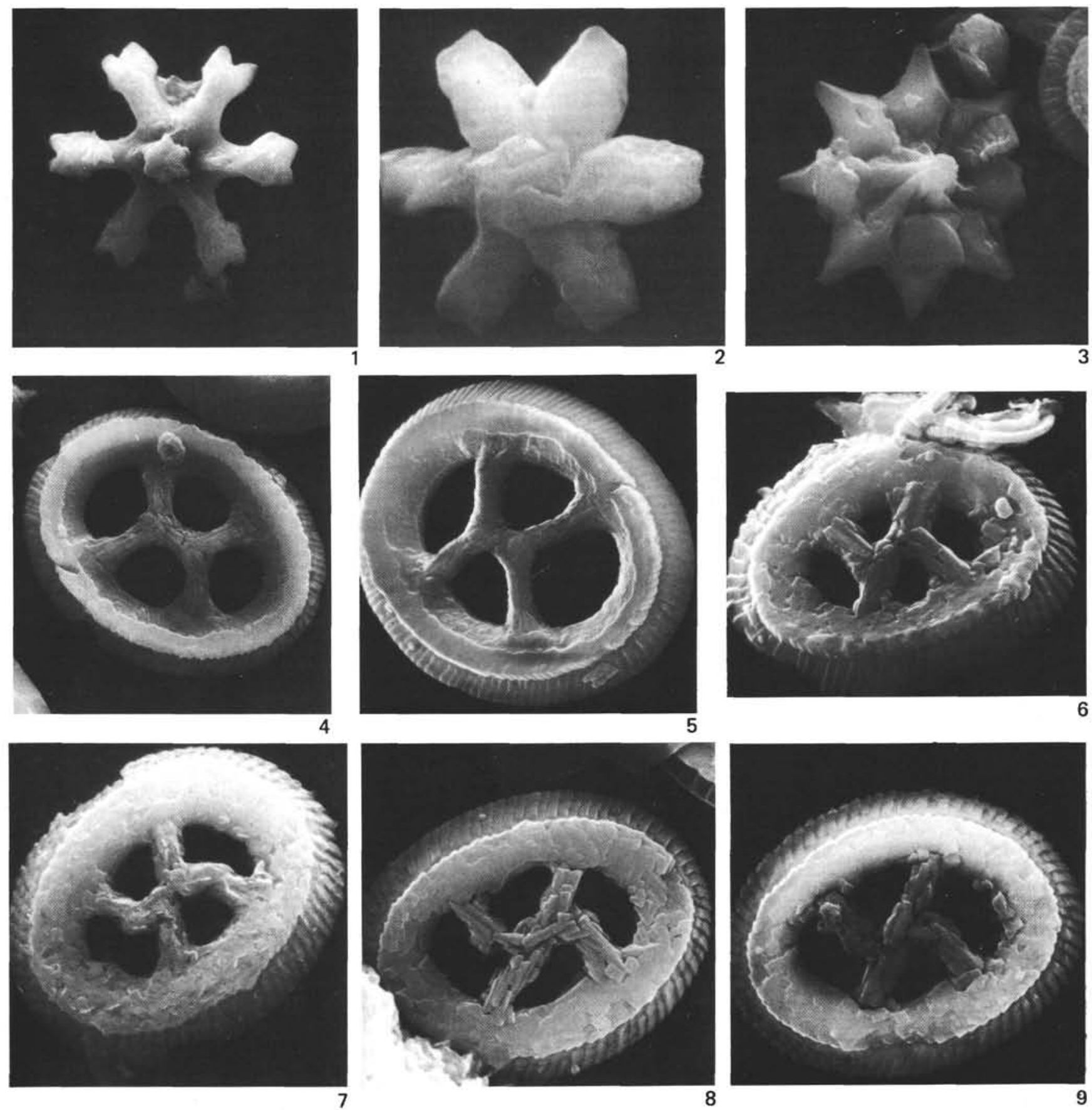

Plate 7. Middle Eocene. 1. Discoaster distinctus Martini, $\times 2600$, Sample $512-7-3,66 \mathrm{~cm} . \quad 2$. Discoaster $\mathrm{sp} ., \times 8000$, Sample $512-7-3,66 \mathrm{~cm}$. 3. Discoaster barbadiensis Tan Sin Hok, $\times 4700$, Sample 512-7-3, $66 \mathrm{~cm} .4-5$. Chiasmolithus expansus (Bramlette and Sullivan) Gartner, D, (4) $\times 2600$, Sample 512-7-3, $66 \mathrm{~cm},(5) \times 3100$, Sample 512-18-3, $110 \mathrm{~cm}$. 6-9. Chiasmolithus solitus (Bramlette and Sullivan) Locker, D, (6-8) $\times 5500$, Sample $512-7-3,66 \mathrm{~cm},(9) \times 5000$, Sample $512-18-3,11 \mathrm{~cm}$. 

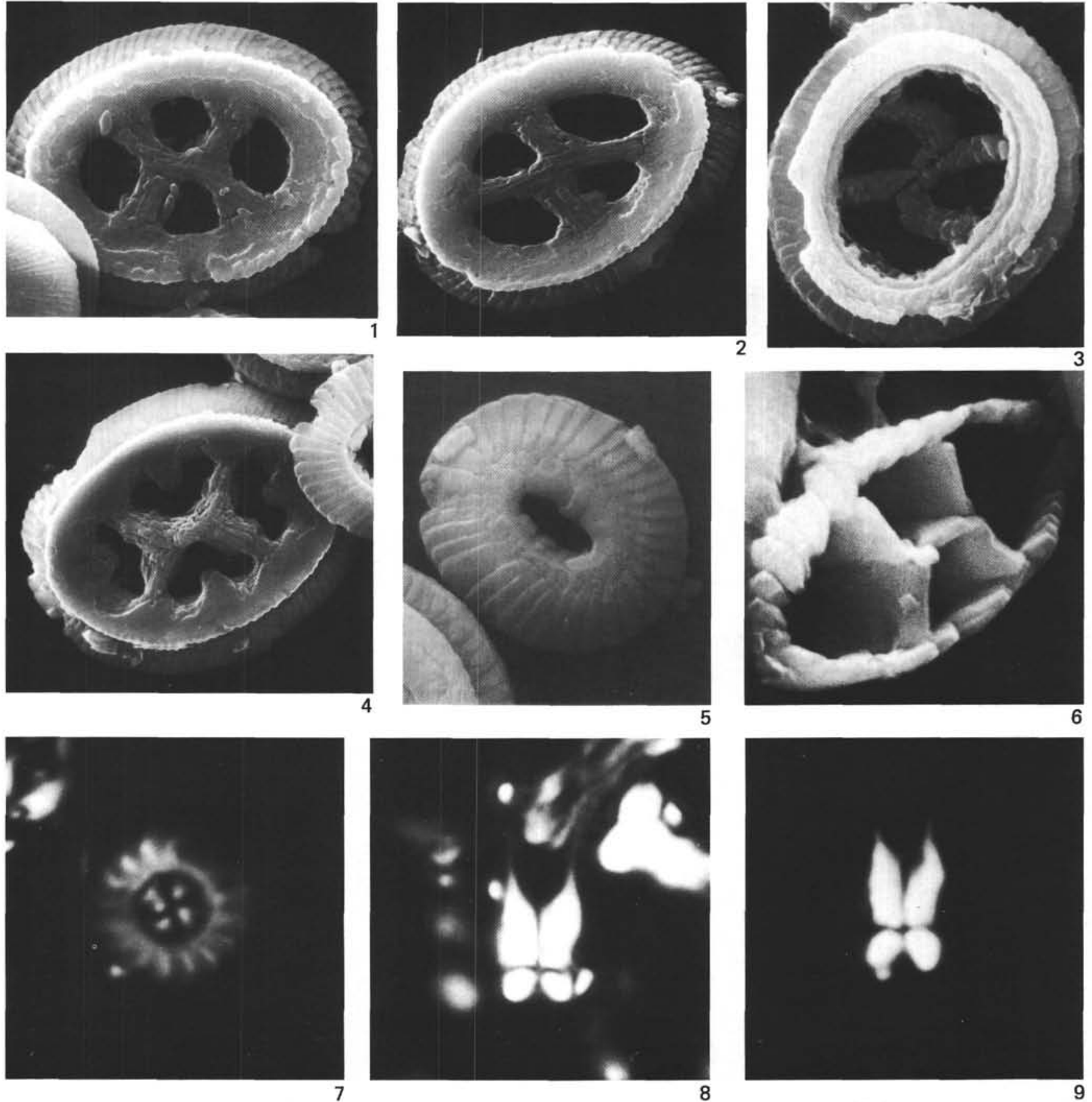

Plate 8. Middle Eocene. 1-2. Chiasmolithus solitus (Bramlette and Sullivan) Locker var. inversus, Wise and Wiegand, n. var., D, Sample 512-7-3, $66 \mathrm{~cm}$, (1) paratype, $\times 3500$, (2) holotype, $\times 3500$. 3. Chiasmolithus solitus (Bramlette and Sullivan) Locker, P, $\times 5000$, Sample $512-18-3,11$ $\mathrm{cm}$. 4. Chiasmolithus grandis (Bramlette and Riedel) Gartner, D, $\times 2500$, Sample $521-18-3,11 \mathrm{~cm} . \quad 5$. Coccolithus pelagicus (Wallich) Schiller, D, $\times 6000$, Sample 512-7-3, $66 \mathrm{~cm}$. 6. Neococcolithes dubius (Deflandre) Black, D, $\times 11,500$, Sample 512-7-3, $66 \mathrm{~cm}$. 7. Markalius inversus (Deflandre) Bramlette and Martini, $\times 5200$ Pol, Sample $512-8-1,73 \mathrm{~cm}$. 8-9. Sphenolithus furcatolithoides Locker, Pol, $\times 6000,(8)$ Sample $512 \mathrm{~A}-2-5,66 \mathrm{~cm}$, (9) Sample 512A-2-1, $89 \mathrm{~cm}$. 

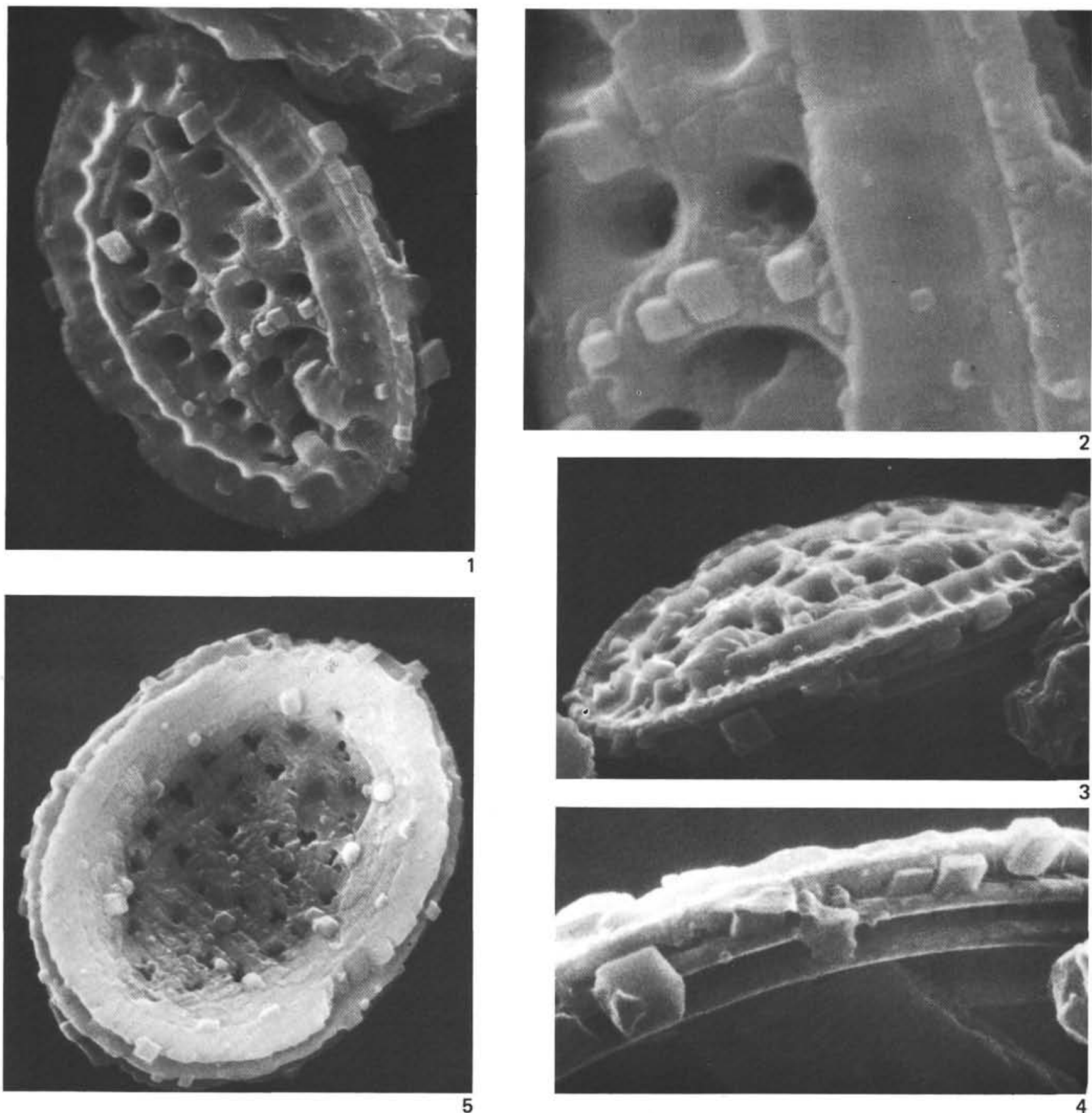

Plate 9. Santonian-Coniacian. 1-5. Broinsonia parca expansa Wise and Watkins, n. ssp. Sample $511-44-5,40 \mathrm{~cm},(1-4)$ holotype $(1, \mathrm{D}, \times 9000$; 2 , detail of pore structure, $\times 36,000 ; 3, \mathrm{DL}, \times 9500 ; 4$, L, detail of rim, $\times 15,000),(5)$ paratype, $\mathrm{P}, \times 7000$. 

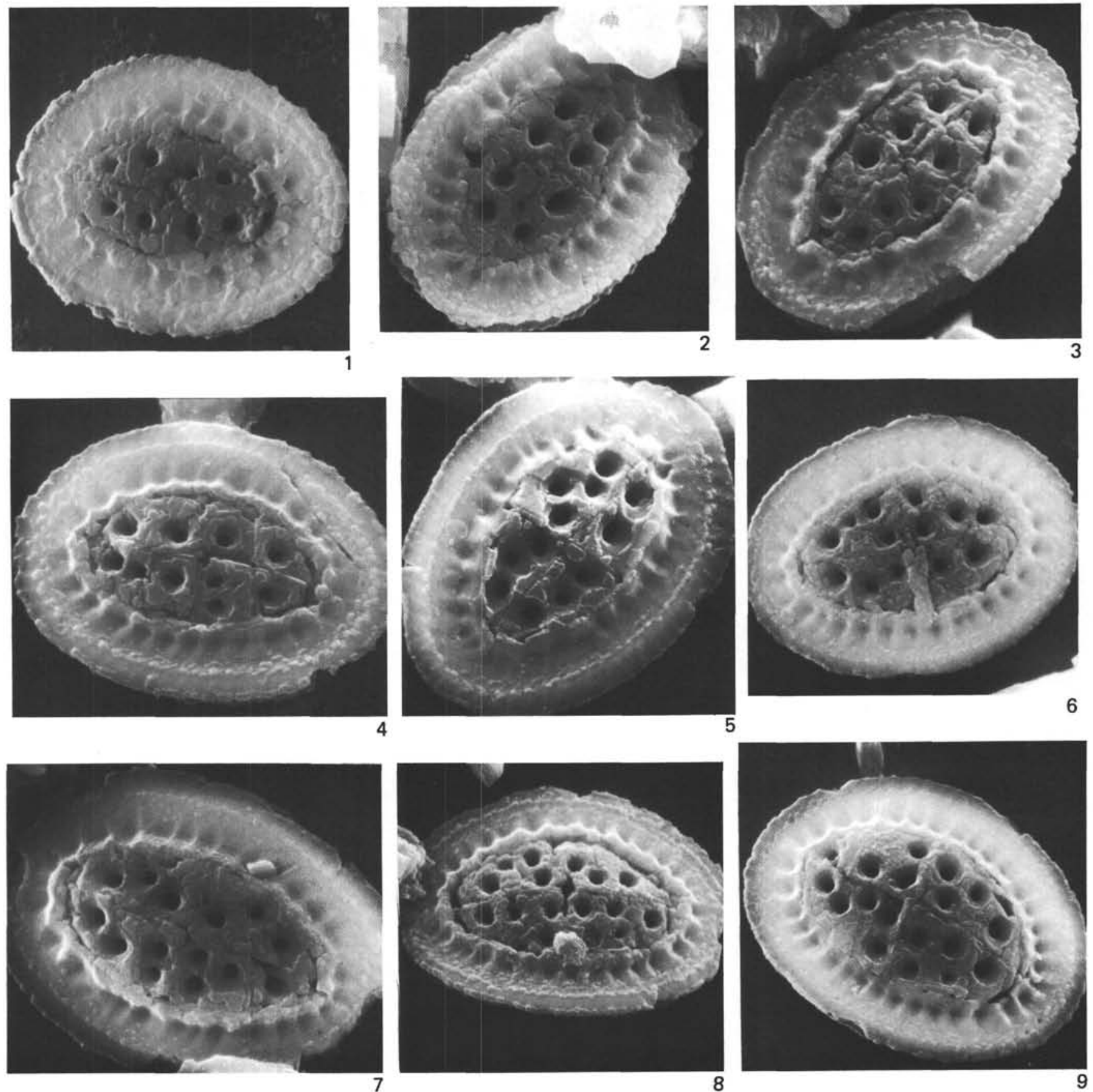

Plate 10. Campanian; all Sample 511-28-7, $15 \mathrm{~cm}$, P. 1-2. Broinsonia ssp. aff. B. parca constricta Hattner, Wind, and Wise, (1) $\times 5500$, (2) $\times 5500$. 3-4. Broinsonia parca parca (Stradner) Bukry, (3) $\times 4900$; (4) $\times 5000$. 5-9. Broinsonia parca expansa Wise and Watkins, n. ssp., paratypes, (5) $\times 4900,(6) \times 5500,(7) \times 5500,(8) \times 4000,(9) \times 5200$. 

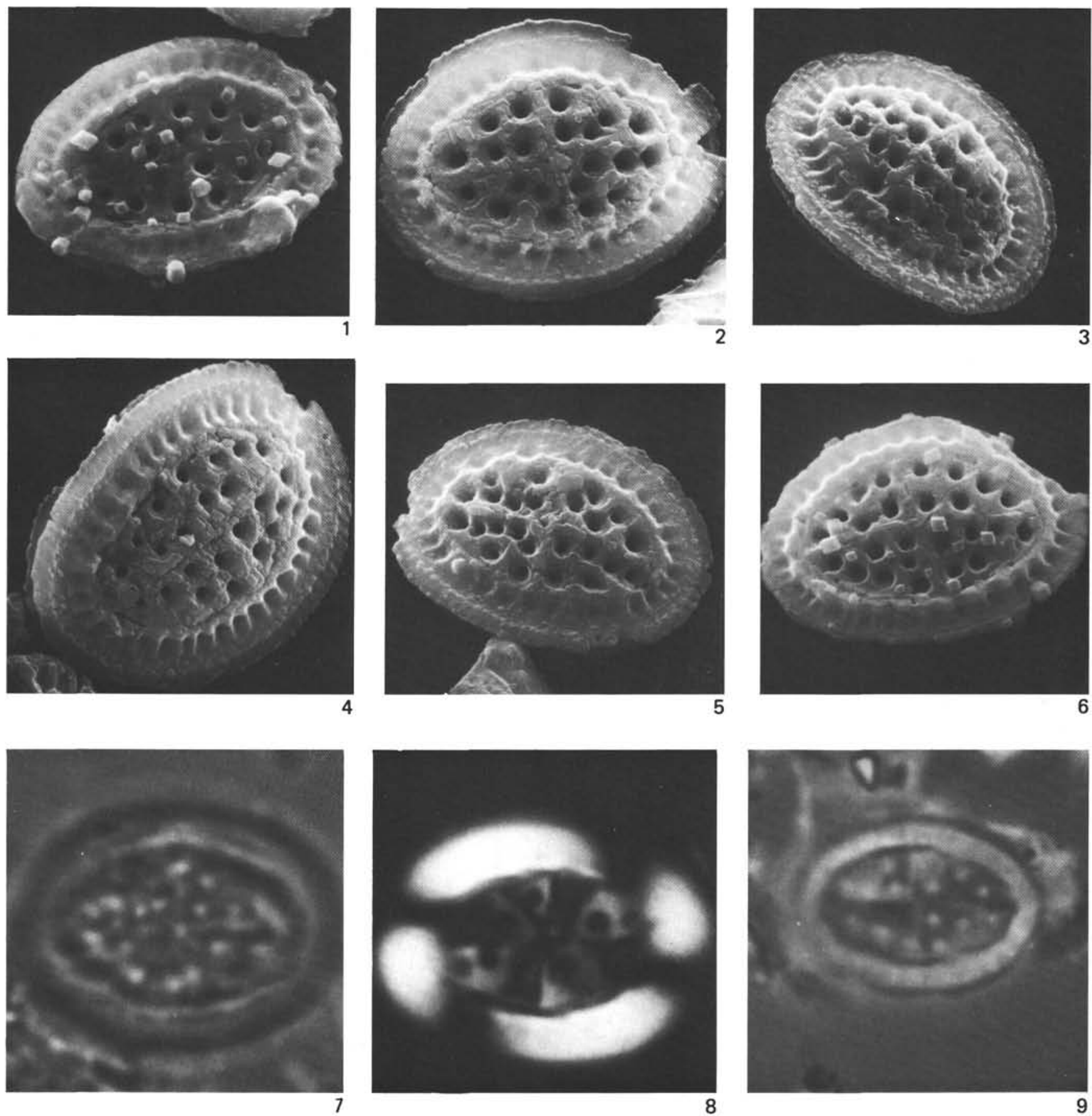

Plate 11. Campanian, Santonian-Coniacian. 1-9. Broinsonia parca expansa Wise and Watkins, n. ssp., paratypes, (1) D, $\times 6500$, Santonian-Coniacian Sample 511-44-5, $40 \mathrm{~cm}$ (2-3) D, Campanian Sample 511-28-7, 15 cm, (2, ×4100; 3, ×3800) (4) D, Campanian Sample 511-28-7, $15 \mathrm{~cm}, \times 4000$; (5) D, $\times 3600$, Campanian Sample 511-28-7, $15 \mathrm{~cm},(6) \mathrm{D}, \times 4800$, Santonian-Coniacian Sample 511-44-5, 40 cm, (7-9) $\times 4800$, Campanian Sample 511-28-7, $15 \mathrm{~cm}(7, \mathrm{Tr} ; 8$, Pol; 9, Ph). 

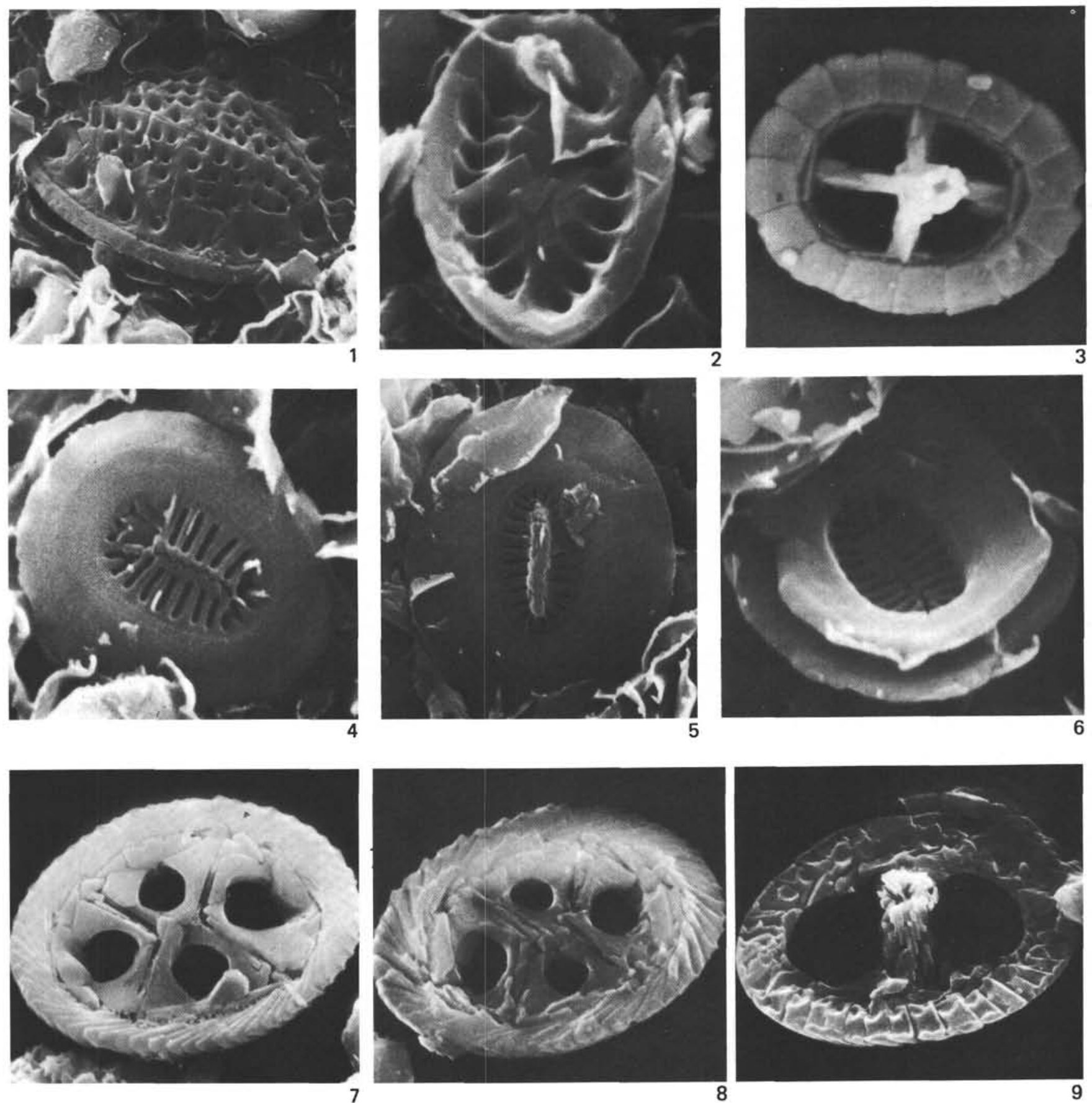

Plate 12. Campanian. 1. Gartnerago confossus (Noël) Noël, D, $\times 6500$, Sample $511-33-3,100 \mathrm{~cm}$. 2. Genus et species indet. 1, D, $\times 18,000$ Sample 511-33-3, $100 \mathrm{~cm}$. 3. Prediscosphaera cretacea (Arkhangelsky) Gartner, D, $\times 11,500$, Sample 511-41-2, 24 cm. 4-6. Repagulum parvidentatum (Deflandre and Fert) Forchheimer, Sample 511-33-3, $100 \mathrm{~cm},(4) \mathrm{D}, \times 21,000,(5) \mathrm{D}, \times 14,500,(6) \mathrm{P}, \times 21,500$. 7-8. Eiffellithus trabeculatus (Gorka) Reinhardt and Gorka, D, Sample 511-41-3, $116 \mathrm{~cm},(7) \times 7500,(8) \times 9500$. 9. Reinhardtites anthophorus (Deflandre) Perch-Nielsen, D, $\times 6500$, Sample $511-41-3,116 \mathrm{~cm}$. 
S. W. WISE, $J_{R}$.
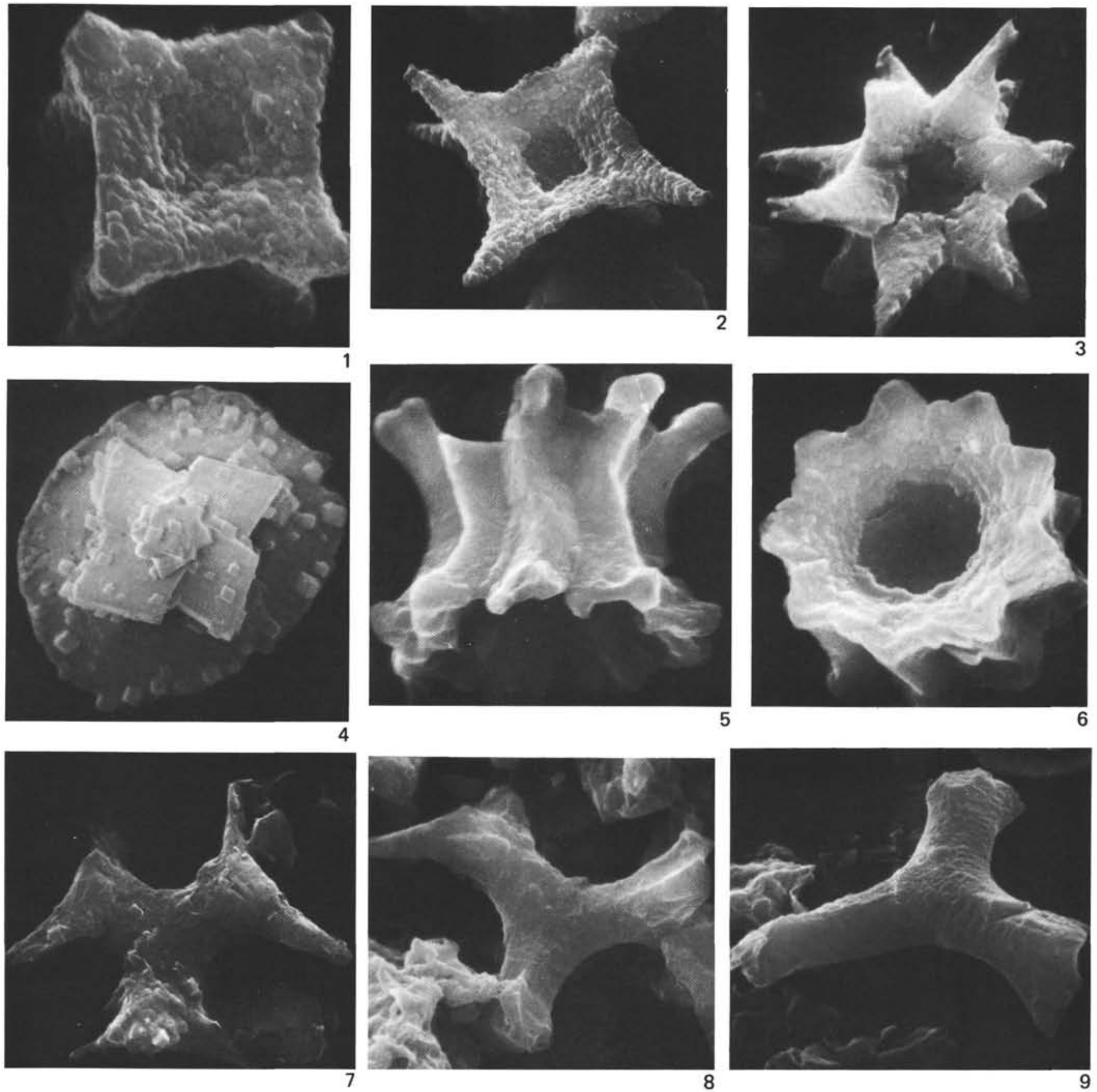

Plate 13. Campanian, Santonian-Coniacian. 1-2. Micula decussata decussata Vekshina, Campanian Sample 511-28-7, 15 cm, (1) $\times 9000$, (2) $\times 5500$. 3. Lithastrinus grillii Stradner, $\times 8000$, Campanian Sample 511-41-3, $116 \mathrm{~cm}$. 4-5. Lithastrinus floralis Stradner, Santonian-Coniacian Sample 511-46-1, $100 \mathrm{~cm},(4) \times 8500$, (5) $\times 9000$. 6. Petrarhabdus copulatus (Deflandre) Wind and Wise, $\mathrm{n}$. comb., D, $\times 6500$, SantonianConiacian Sample 511-44-5, $40 \mathrm{~cm}$. 7-9. Marthasterites furcatus (Deflandre and Fert) Deflandre, Sample 511-46-1, 100 cm, (7) $\times 5500,(8)$ $\times 5000,(9) \times 6500$. 

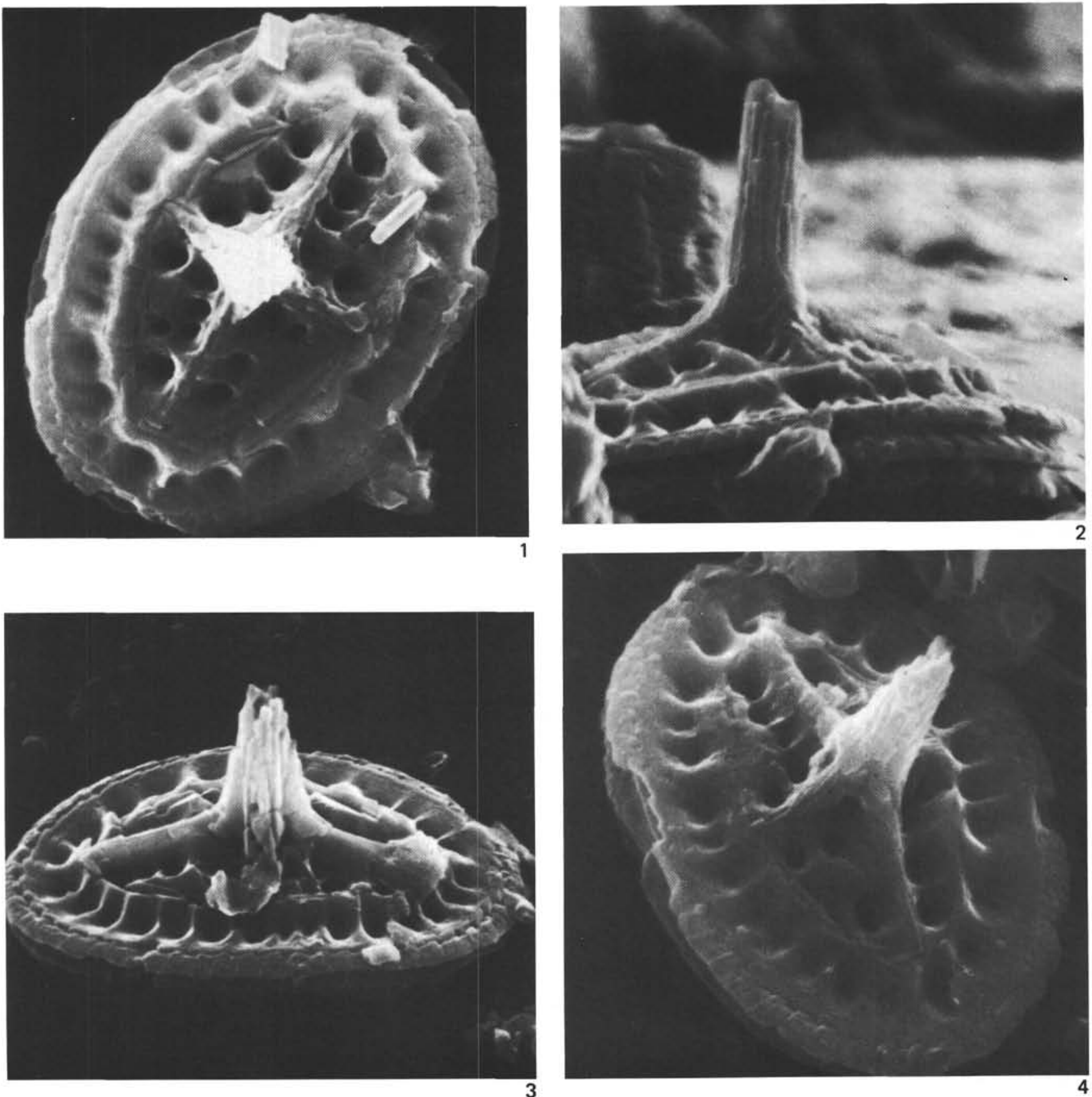

Plate 14. Santonian-Coniacian. 1-4. Thiersteinia ecclesiastica Wise and Watkins, n. gen., n. sp., Sample 511-46-1, 100 cm, (1) holotype, D, $\times 11,000$, (2) holotype, $\mathrm{L}, \times 12,500,(3)$ paratype, $\mathrm{DL}, \times 9,500,(4)$ paratype, $\mathrm{D}, \times 12,000$. 

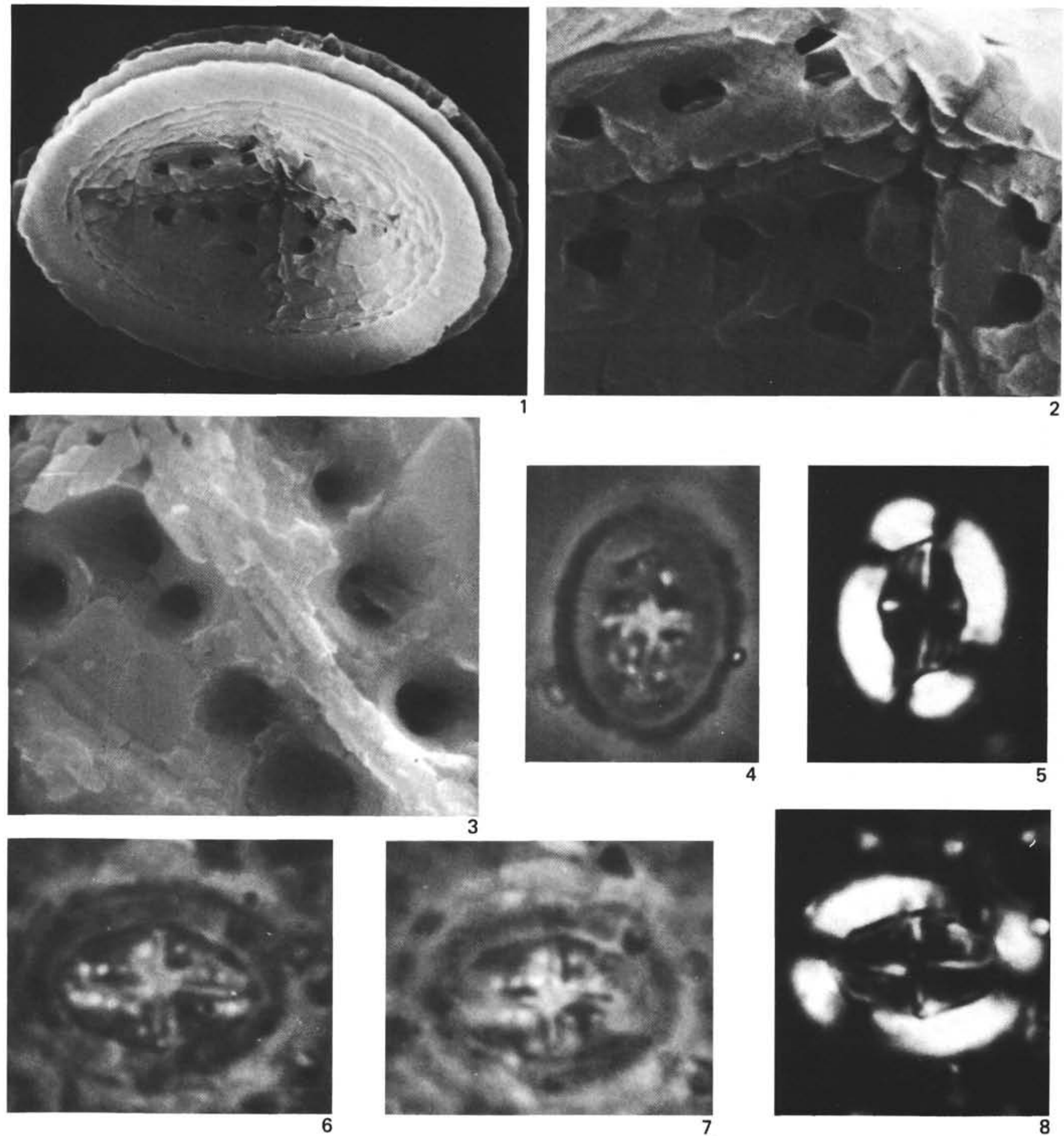

Plate 15. Santonian-Coniacian. 1-8. Thiersteinia ecclesiastica Wise and Watkins n. gen., n. sp., Sample 511-46-1, 100 cm, paratypes, (1-2) PL $(1, \times 11,000 ; 2$, detail showing doublet and triplet pore outlines, $\times 31,000)$, (3) $\mathrm{D}$, singlet, doublet, and triplet pore outlines, $\times 28,500,(4-5)$ $\times 4500,(4, \mathrm{Ph} ; 5, \mathrm{Pol})(6-8) \times 6500,(6$, low focus; $7, \mathrm{Ph}$, high focus; $8, \mathrm{Pol})$. 

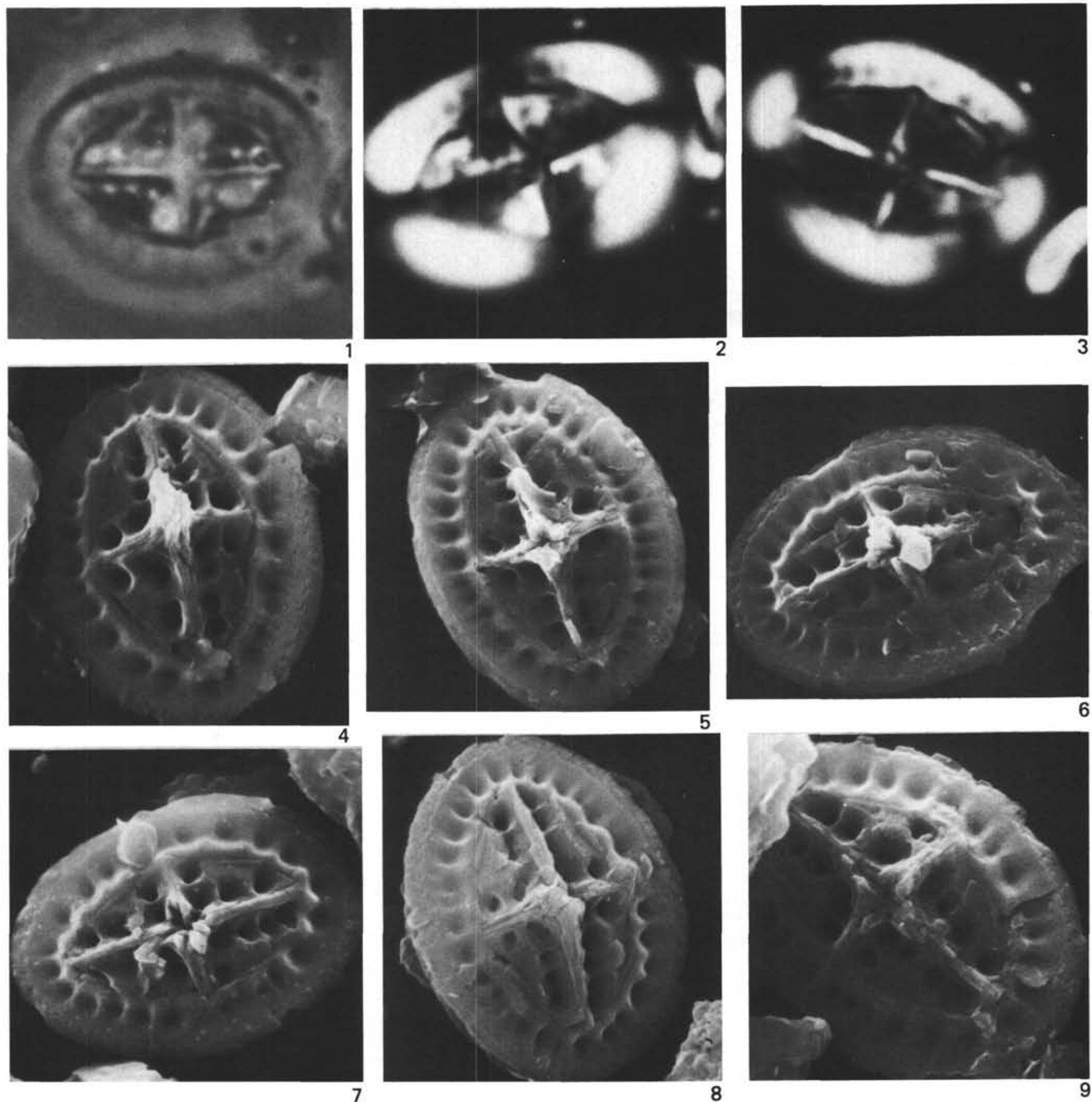

Plate 16. Santonian-Coniacian. 1-9. Thiersteinia ecclesiastica Wise and Watkins, n. gen., n. sp., Sample 511-46-1, 100 cm, paratypes, (1-3) same specimen $\left(1, \mathrm{Ph}, \times 4700 ; 2, \mathrm{Pol},+22^{1 / 2} 2^{\circ}, \times 5500 ; 3, \mathrm{Pol},-22^{1 / 2^{\circ}}, \times 5500\right),(4) \mathrm{D}, \times 6500,(5-6) \mathrm{D}, \times 7000,(7) \mathrm{D}, \times 6500,(8) \mathrm{D}, \times 7000$, (9) $\mathrm{D}, \times 8000$. 

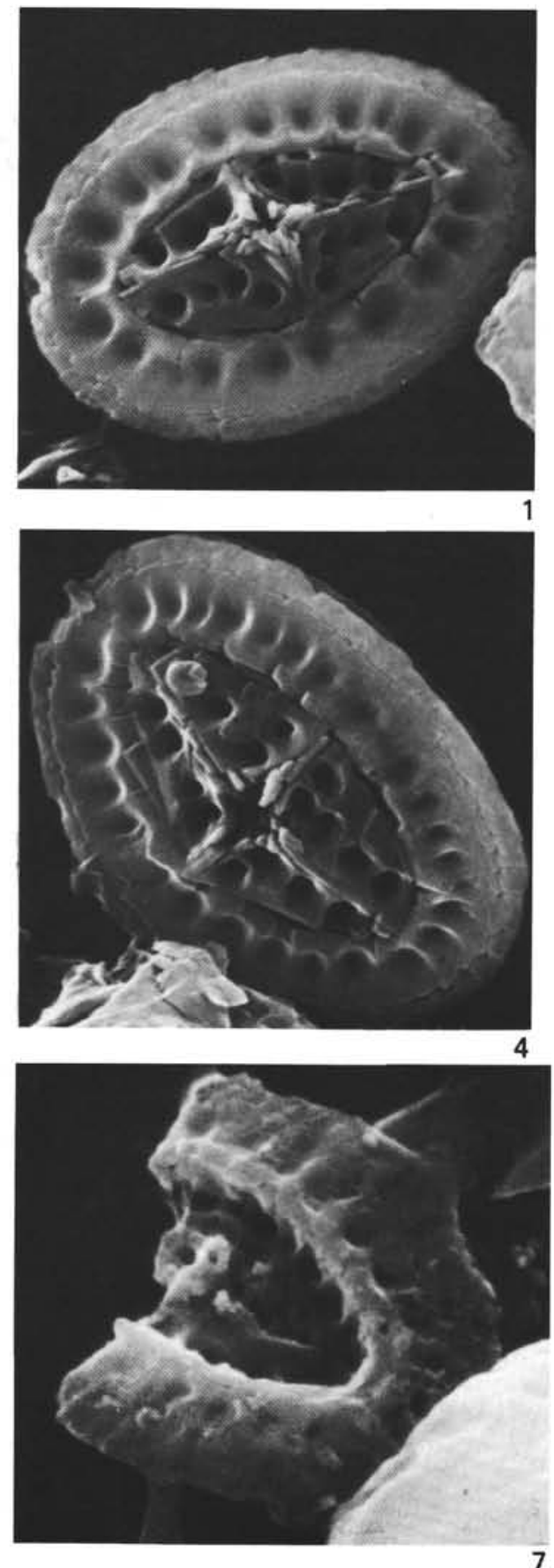
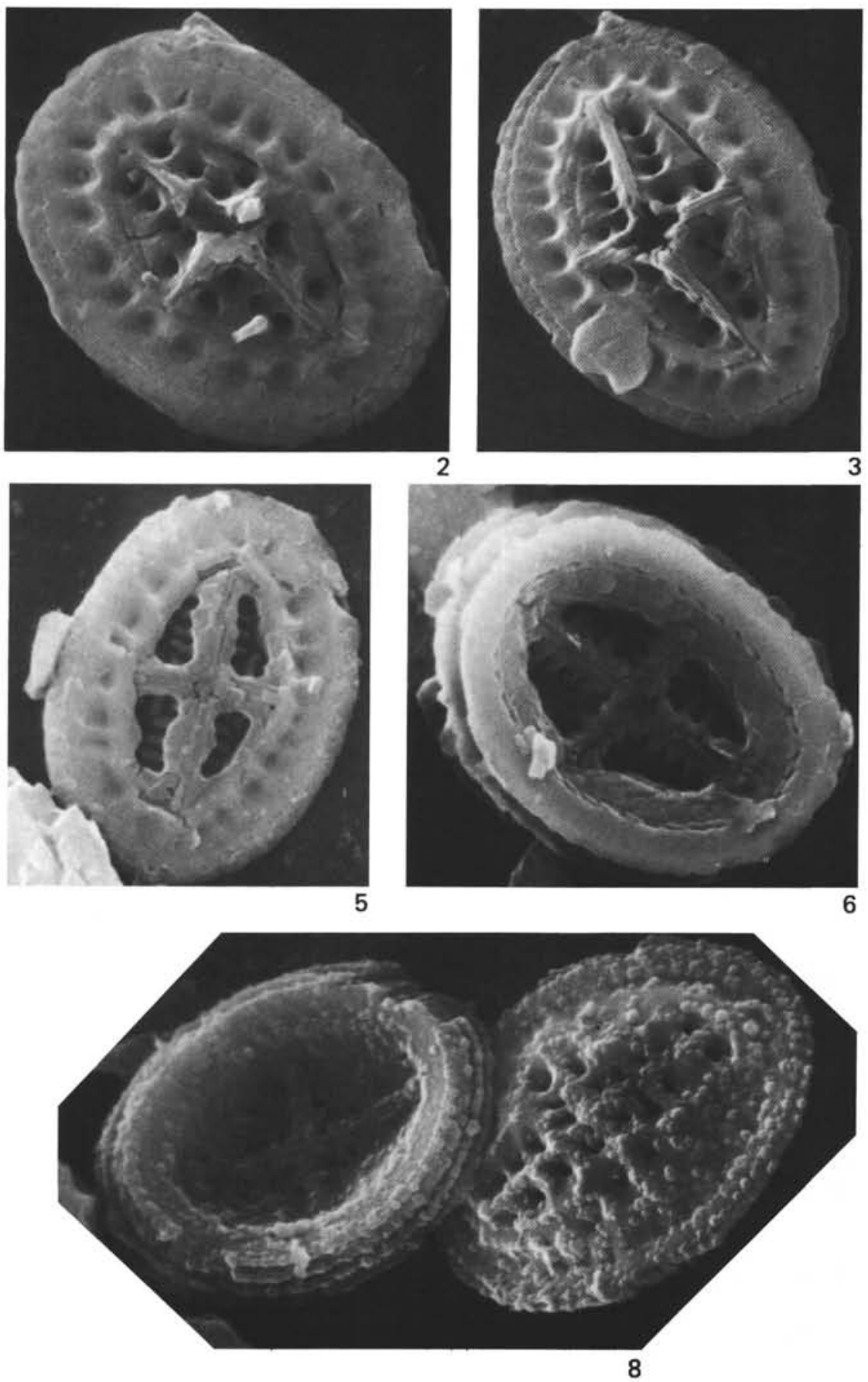

Plate 17. Campanian, Santonian-Coniacian. 1-4. Thiersteinia ecclesiastica Wise and Watkins, n. gen., n. sp., Sample 511-46-1, 100 cm, paratypes, (1-2) D, $\times 8000$, (3) D, $\times 7500$, (4) D, $\times 9000$. 5-6. Broinsonia dentata Bukry, Sample $511-46-1,100 \mathrm{~cm},(5) \mathrm{D}, \times 8500,(6) \mathrm{P}, \times 9500$. 7. Biscutum hattneri Wise, n. sp., D, $\times 14,000$, Santonian-Coniacian Sample $511-46-1,100 \mathrm{~cm}$. 8. Gartnerago costatum (Gartner) Bukry, D (left), P (right), $\times 5500$, Sample $511-28-7,15 \mathrm{~cm}$. 

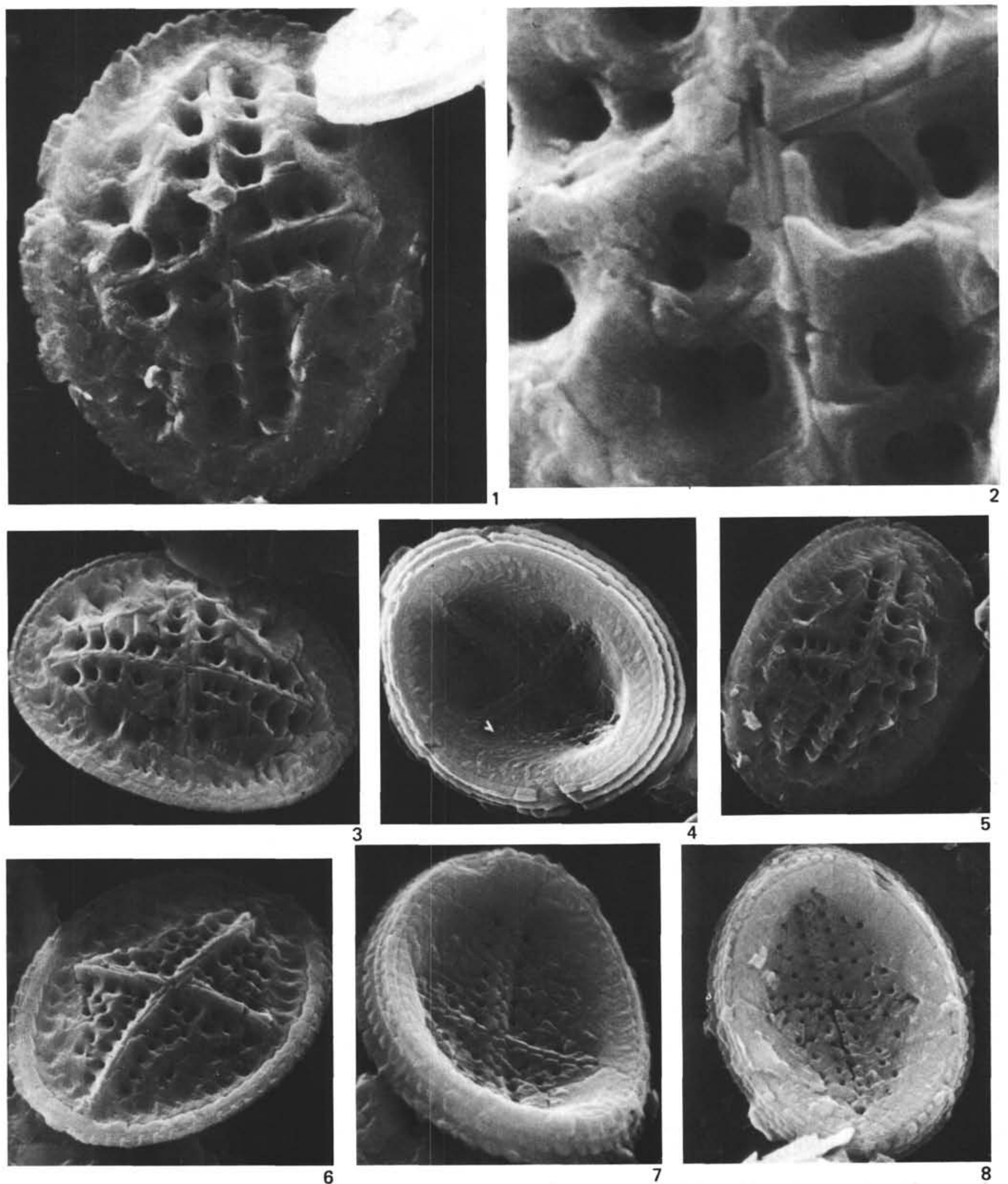

Plate 18. Santonian-Coniacian, all from Sample 511-46-1, $100 \mathrm{~cm}$. 1-5. Gartnerago costatum (Gartner) Bukry, (1) D, $\times 11,000,(2)$ same specimen, detail of perforation patterns, $\times 36,000,(3) \mathrm{D}, \times 6000,(4) \mathrm{P}, \times 7000,(5) \mathrm{D}, \times 5500$. 6-8. Gartnerago confossus (Noël) Noël, (6) D, $\times 7500$, (7) $\mathrm{P}, \times 9500,(8) \mathrm{P}, \times 7200$. 

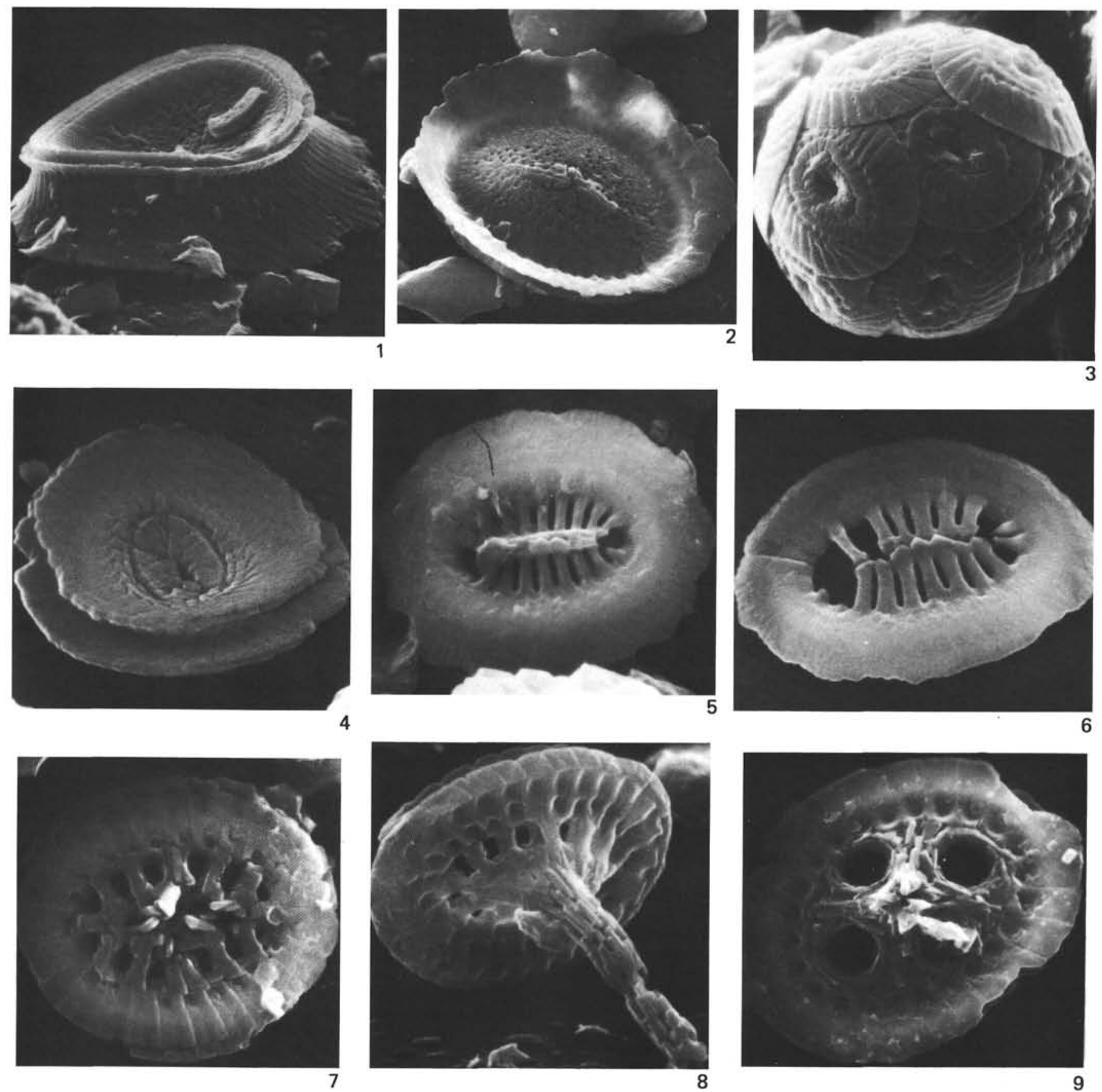

Plate 19. Santonian-Coniacian, all from Sample 511-46-1, $100 \mathrm{~cm} . \quad 1-2$. Kamptnerius magnificus Deflandre, (1) PL, $\times 3900,(2) \mathrm{D}, \times 3300$. 34. Watznaueria barnesae (Black) Perch-Nielsen, (3) D, $\times 4400$, (4) $\mathrm{P}, \times 10,500$. 5-6. Repagulum parvidentatum (Deflandre and Fert) Forchheimer, D, (5) $\times 12,500,(6) \times 13,500$. 7-8. Cretarhabdus surirellus (Deflandre and Fert) Reinhardt, D, (7) $\times 10,000,(8) \times 9000$. 9. Grantarhabdus coronadventis (Reinhardt) Grün, D, $\times 8000$. 

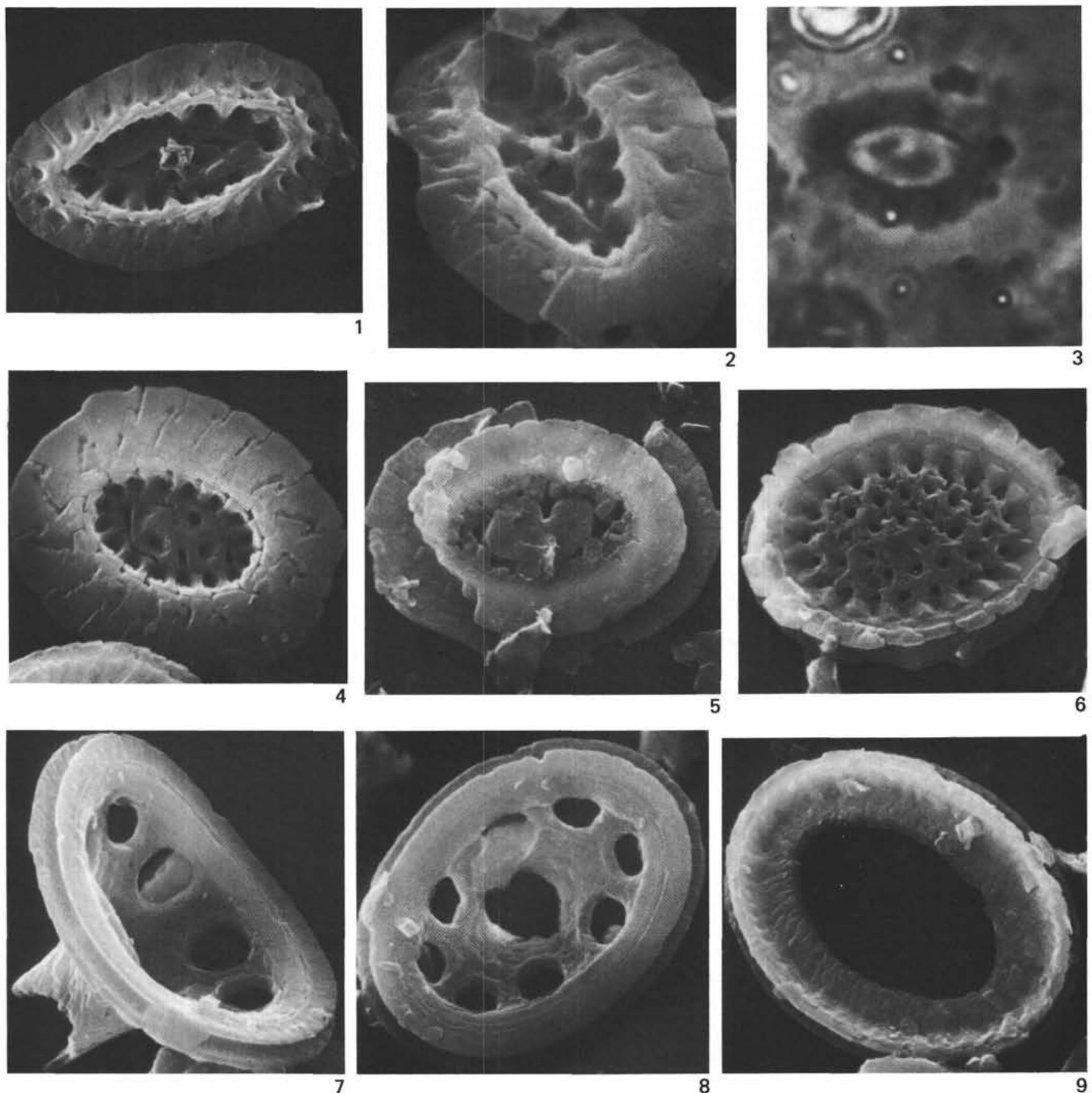

Plate 20. Santonian-Coniacian, all from Sample 511-46-1, $100 \mathrm{~cm} . \quad 1-3$. Biscutum hattneri Wise, n. sp., D; (1) holotype, D, $\times 10,000$; (2) paratype, D, $\times 14,500 ;(3) \mathrm{Ph}, \times 6500$. 4-5. Seribiscutum primitivum (Thierstein) Filewicz, Wind and Wise, (4) D, $\times 7500,(5) \mathrm{P}, \times 6500$. 6. Cribrosphaera ehrenbergi (Arkhangelsky) Deflandre, D, $\times 11,000$. 7-8. Octocyclus reinhardtii (Bukry) Wind and Wise, (7-8) PL (7, $\times 4300 ; 8$, $\times 4100$ ). 9. Manivitella pemmatoidea (Deflandre ex Manivit) Thierstein, D, $\times 4800$. 

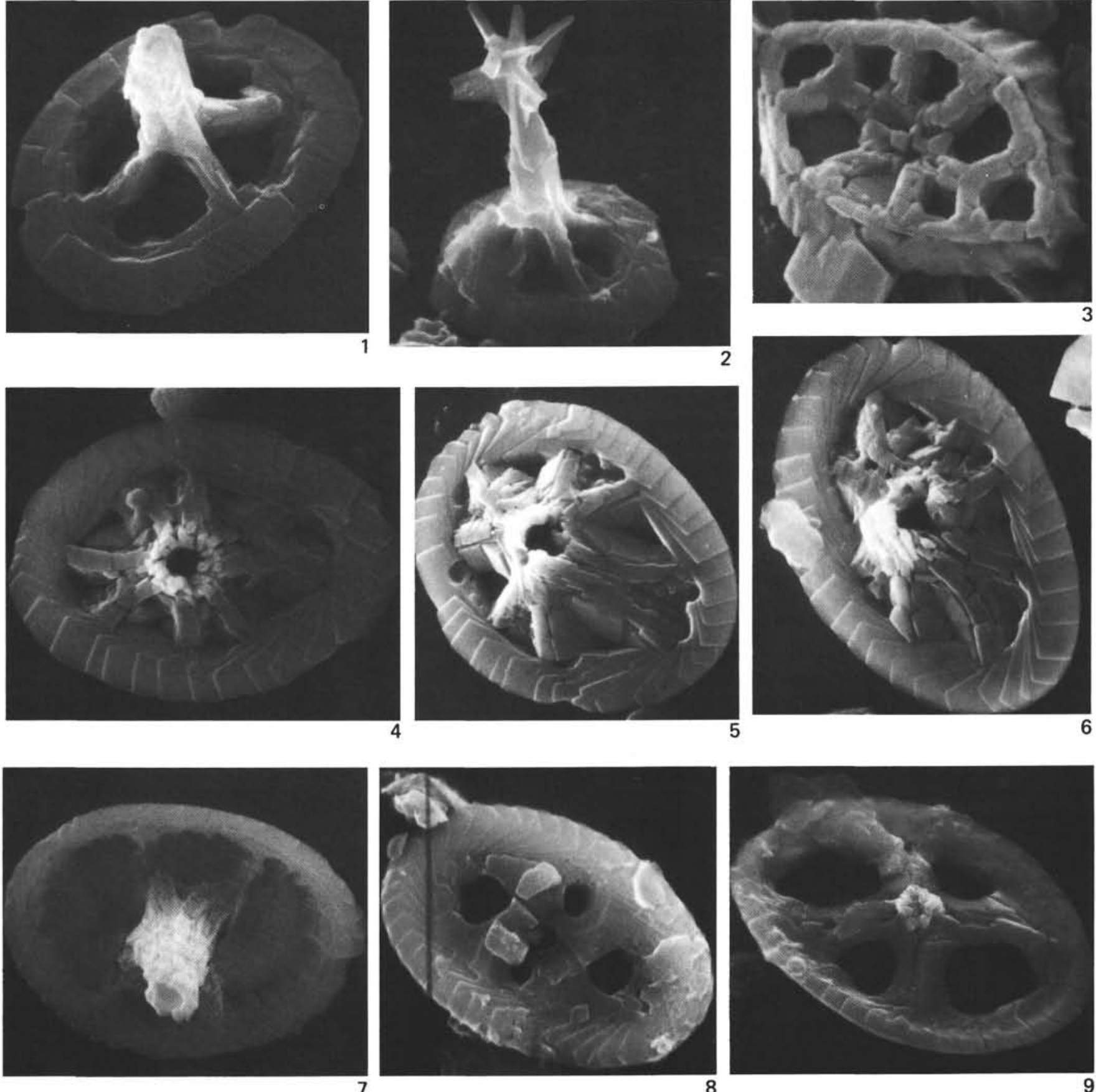

Plate 21. Santonian-Coniacian, all from Sample 511-46-1, $100 \mathrm{~cm}$. 1. Prediscosphaera spinosa (Bramlette and Martini) Gartner, D, $\times 11,500$. 2. Prediscosphaera cretacea (Arkhangelsky) Gartner, D, $\times 7500$. 3. Corollithion rhombicum (Stradner and Adamiker) Bukry, P, Sample $\times 15,000$. 4-6. Ahmuellerella octoradiata (Gorka) Reinhardt, D, (4) $\times 11,000,(5) \times 8,000,(6) \times 10,500$. 7. Eiffellithus turriseiffeli (Deflandre and Fert) Reinhardt, D, $\times 7500$. 8. Tranolithus orionatus Stover, D, $\times 8000$. 9. Chiastozygus synquadriperforatus Bukry, D, $\times 9500$. 

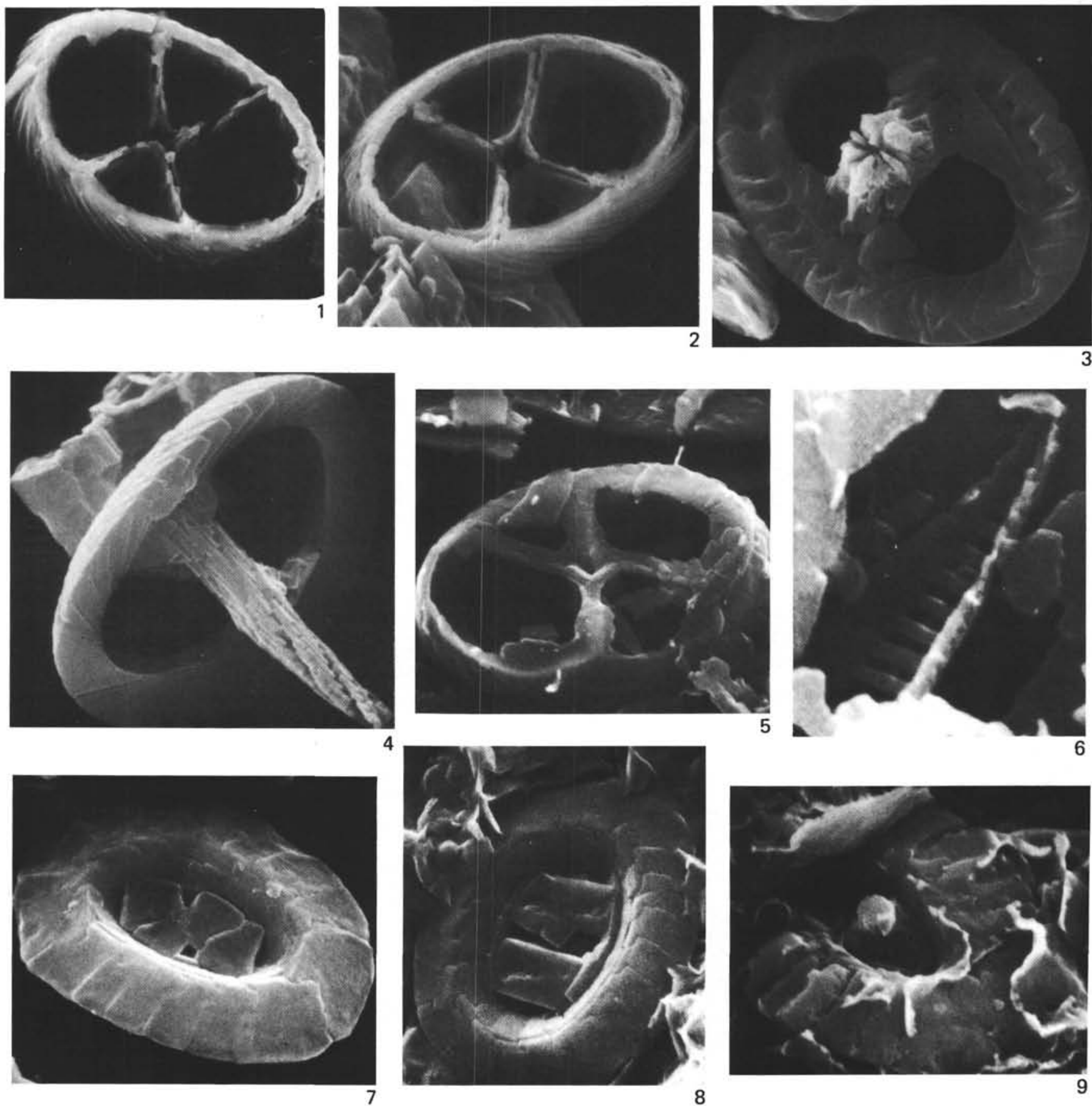

Plate 22. Santonian-Coniacian, Albian. 1-2. Chiastozygus sp., P, Santonian-Coniacian Sample $511-46-1,100 \mathrm{~cm}(1) \times 6000,(2) \times 75000$. 3 . Reinhardtites sp., D, $\times 7500$, Santonian-Coniacian Sample 511-46-1, $100 \mathrm{~cm} . \quad 4$. Zygodiscus? sp., DL, $\times 8000$, Santonian-Coniacian Sample 511-46-1, $100 \mathrm{~cm}$. 5. Chiastozygus sp., P, $\times 17,000$, Albian Sample 511-57-6, $4 \mathrm{~cm}$. 6. Scapholithus fossilis Deflandre, D, $\times 34,500$, Albian Sample 511-57-6, $4 \mathrm{~cm}$. 7-8. Seribiscutum primitivum (Thierstein) Filewicz, Wind, and Wise, (7) D, $\times 12,000$, Albian Sample 511-51-4, 58 cm, (8) D, form transitional to Seribiscutum bijugum Wind and Wise, $\times 10,000$, Sample 511-52-6, $58 \mathrm{~cm}$. 9. Palaeopontosphaera dubia Noël, D, $\times 17,500$, Albian Sample 511-57-6, $15 \mathrm{~cm}$. 
S. W. WISE, JR.
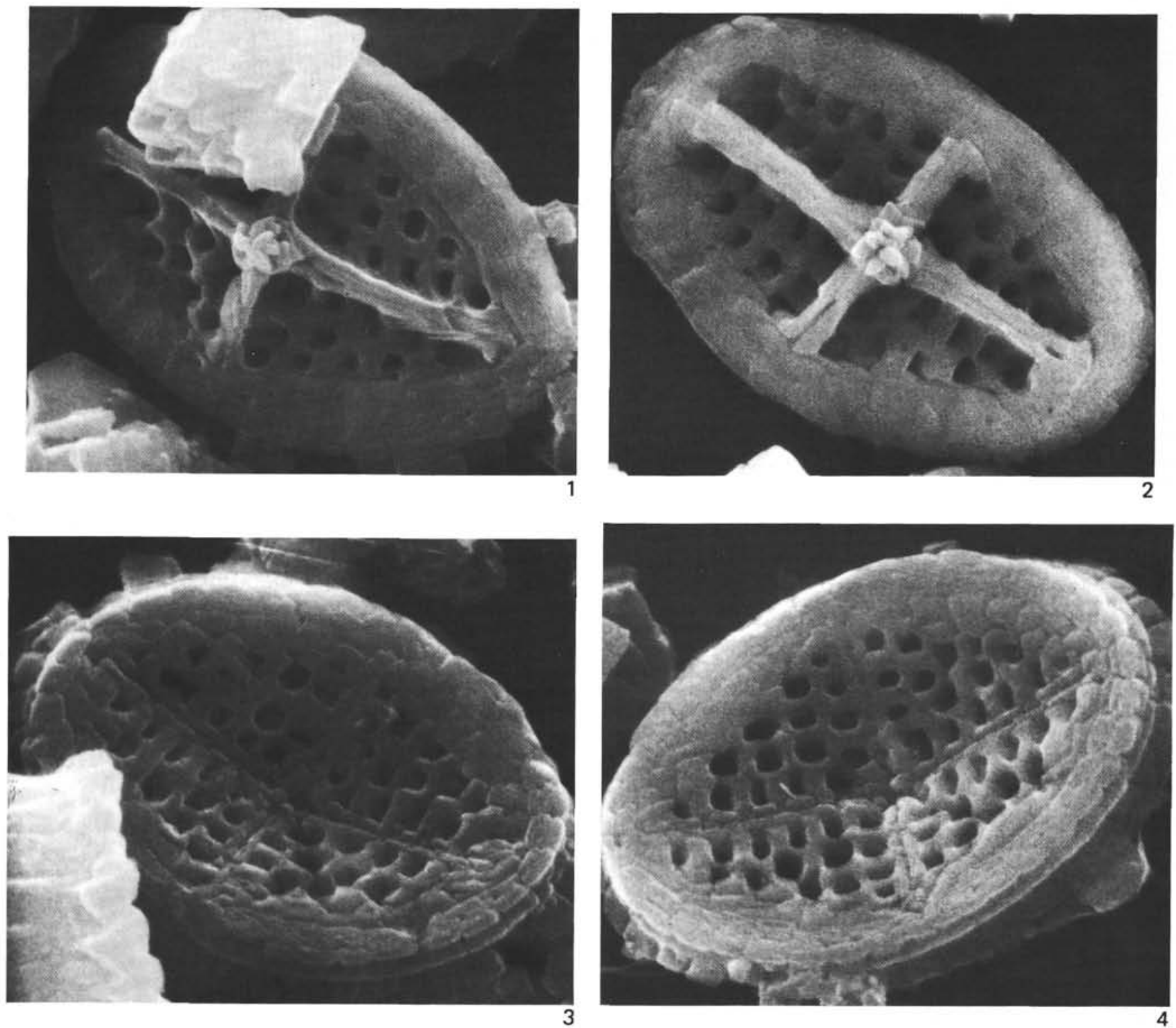

Plate 23. Albian. 1-4. Crucicribrum striatum constansii Wise and Parker, n. ssp., Sample 511-52-6, $58 \mathrm{~cm},(1)$ holotype, D, $\times 15,000,(2)$ paratype, $\mathrm{D}, \times 15,500,(3)$ paratype, $\mathrm{P}, \times 16,000,(4)$ paratype, $\mathrm{P}, \times 17,000$. 

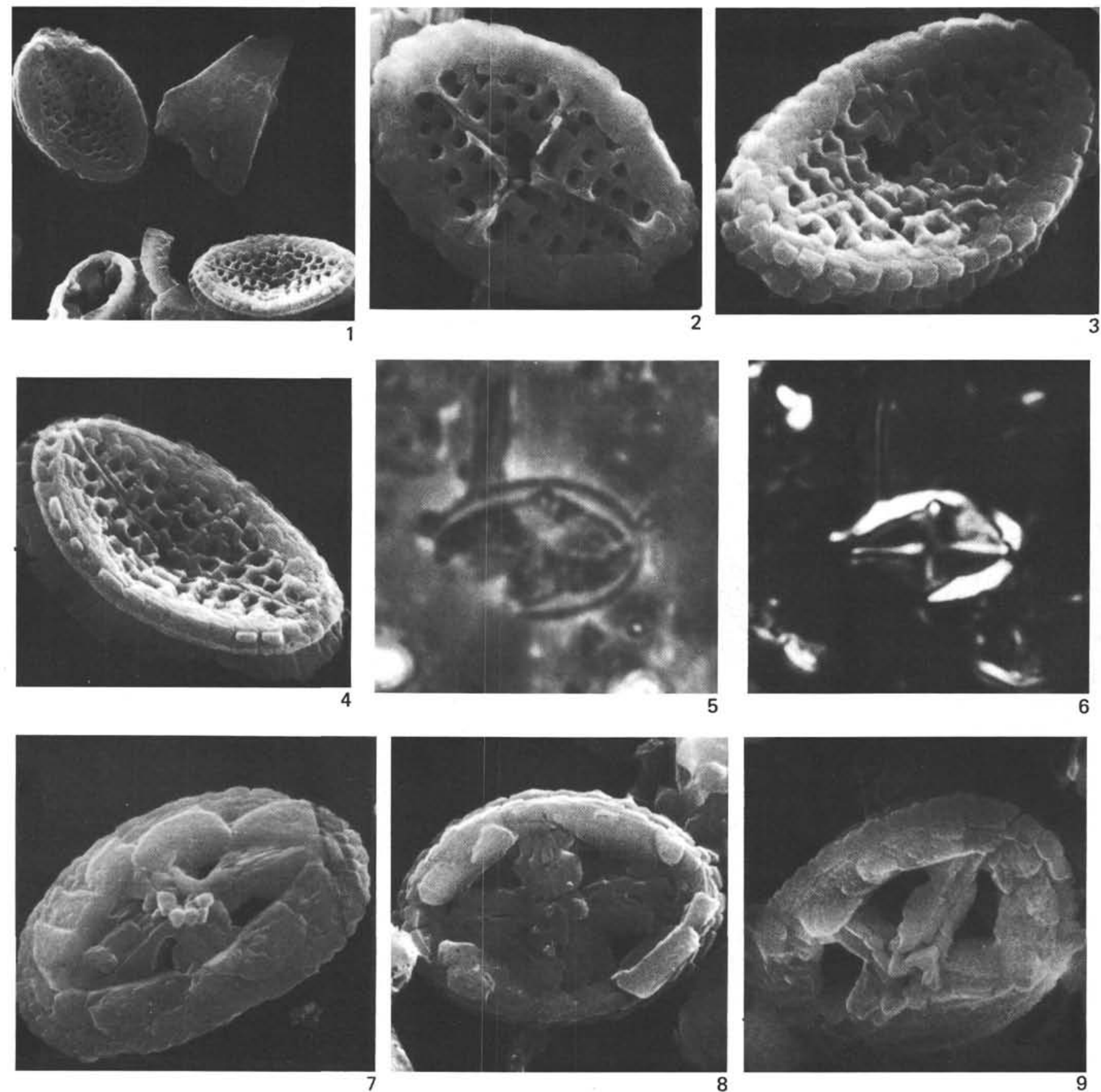

Plate 24. Albian. 1-6. Crucicribrum striatum constansii Wise and Parker, n. ssp., paratypes, Sample 511-52-6, 58 cm, (1) P, upper left and lower right, $\times 5000,(2) \mathrm{D}, \times 12,000,(3) \mathrm{PL}, \times 18,000,(4) \mathrm{PL}, \times 11,000,(5-6) \times 5000(5, \mathrm{Ph} ; 6, \mathrm{Pol})$. 7-9. Acaenolithus sp., D, (7) $\times 6500$, Sample $330-2-2,26 \mathrm{~cm},(8) \times 8000$, Sample $330-2-2,26 \mathrm{~cm},(9) \times 12,500$, Sample $511-55-6,32 \mathrm{~cm}$. 

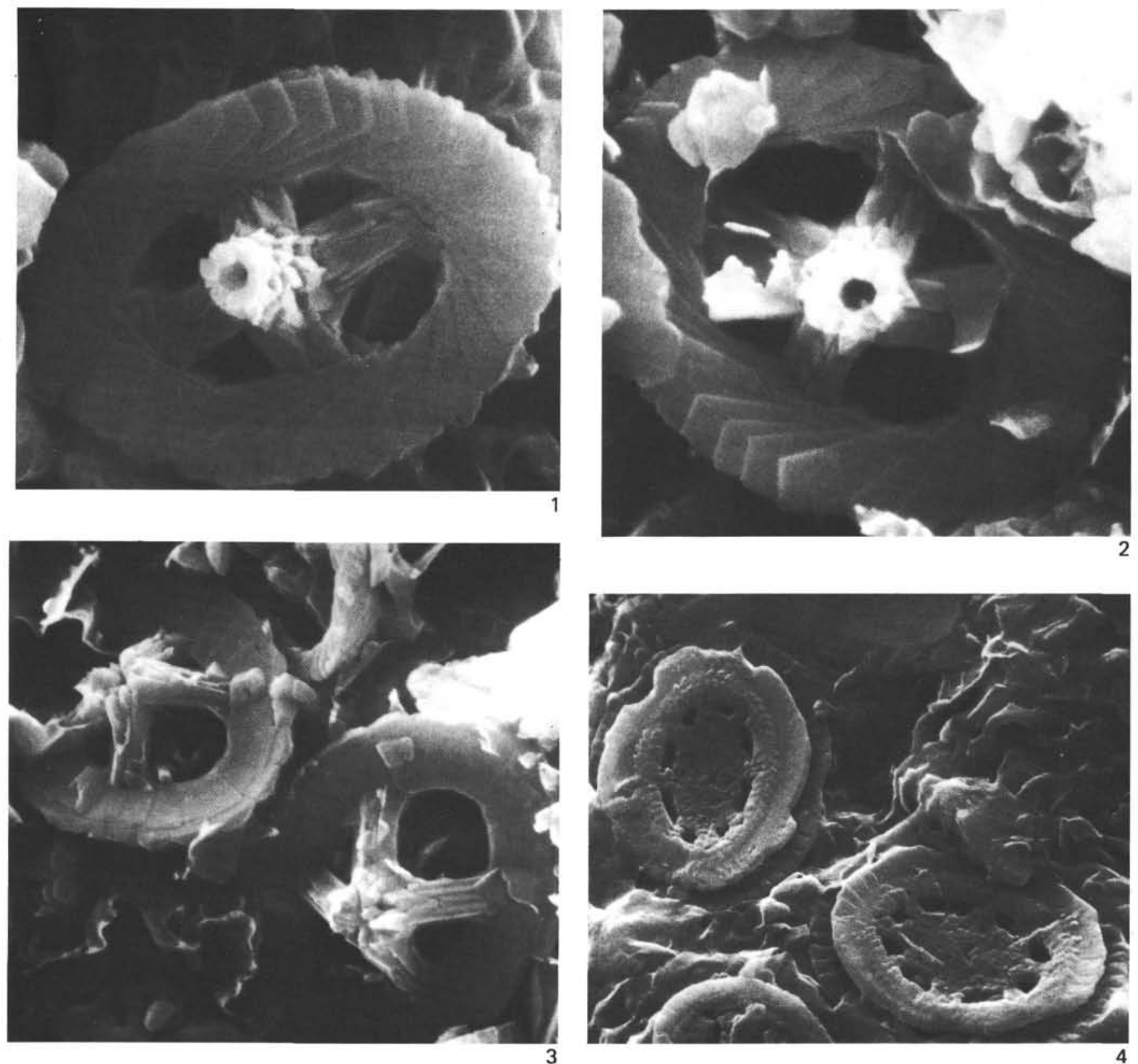

Plate 25. Albian. 1-2. Chiastozygus angustus (Stover) Wise, n. comb., D, Sample 511-55-6, $32 \mathrm{~cm},(1) \times 19,000,(2) \times 17,500$. 3. Grantarhabdus coronadventis (Reinhardt) Grün, D, $\times 12,000$, Sample $511-55-6,32 \mathrm{~cm}$. 4. Sollasites falklandensis Filewicz, Wind and Wise, P, $\times 6000$, Sample 511-52-6, $58 \mathrm{~cm}$. 

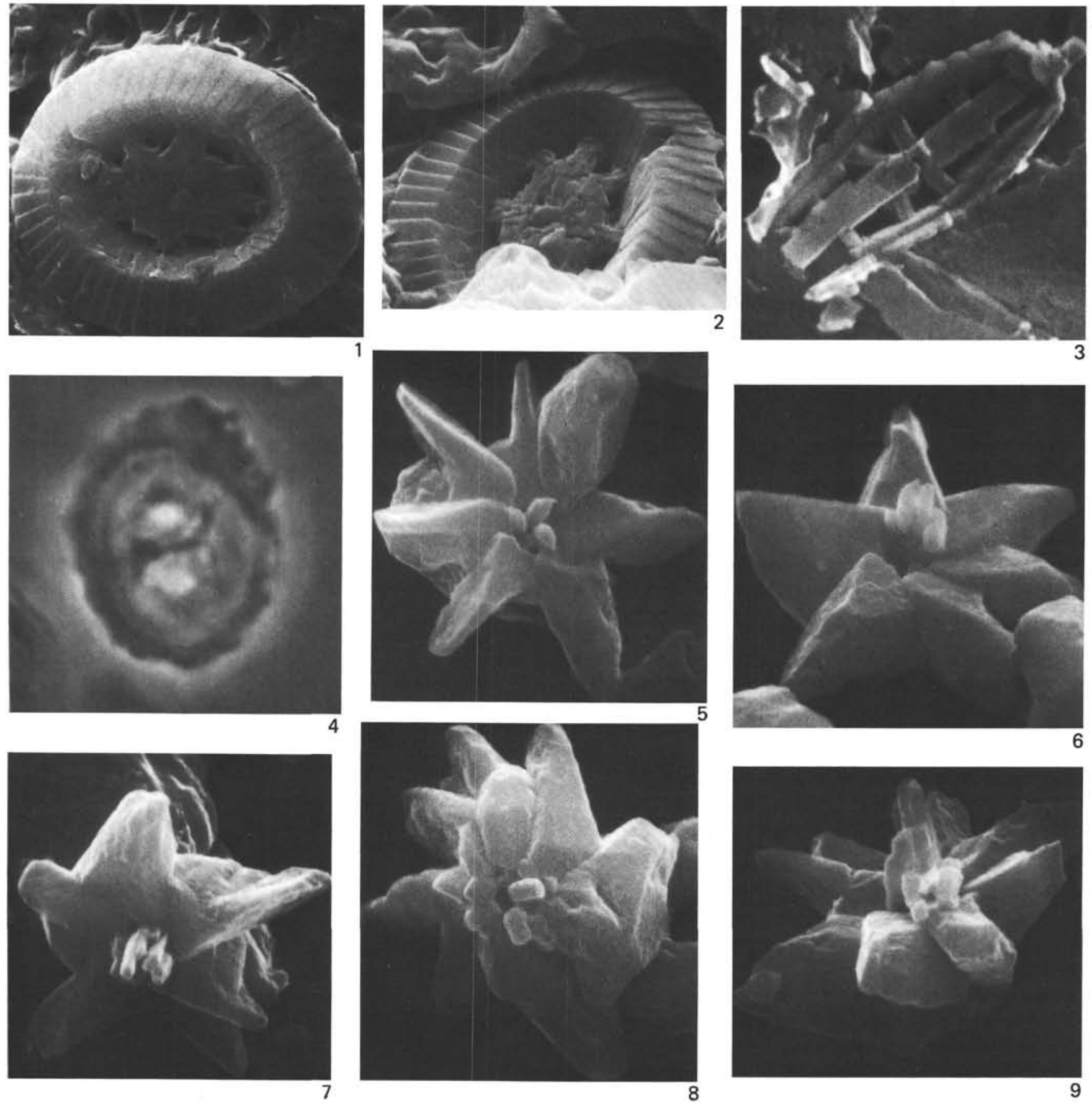

Plate 26. Albian. 1-2. Sollasites falklandensis Filewicz, Wind, and Wise, D, Sample 511-52-6, $58 \mathrm{~cm},(1) \times 7500,(2) \times 9000$. 3. Corollithion pauciramosus (Black) Wise n. comb. D, $\times 22,000$, Sample 511-57-6, $4 \mathrm{~cm}$. 5. Flabellites oblongus (Bukry) Crux, Ph, $\times 5500$, Sample 511-55-1, $32 \mathrm{~cm}$. 6-9. Hayesites albiensis Manivit, Sample 511-51-4, $58 \mathrm{~cm},(6) \times 16,500$, (7) $\times 14,500,(8) \times 14,000,(9) \times 17,000$. 

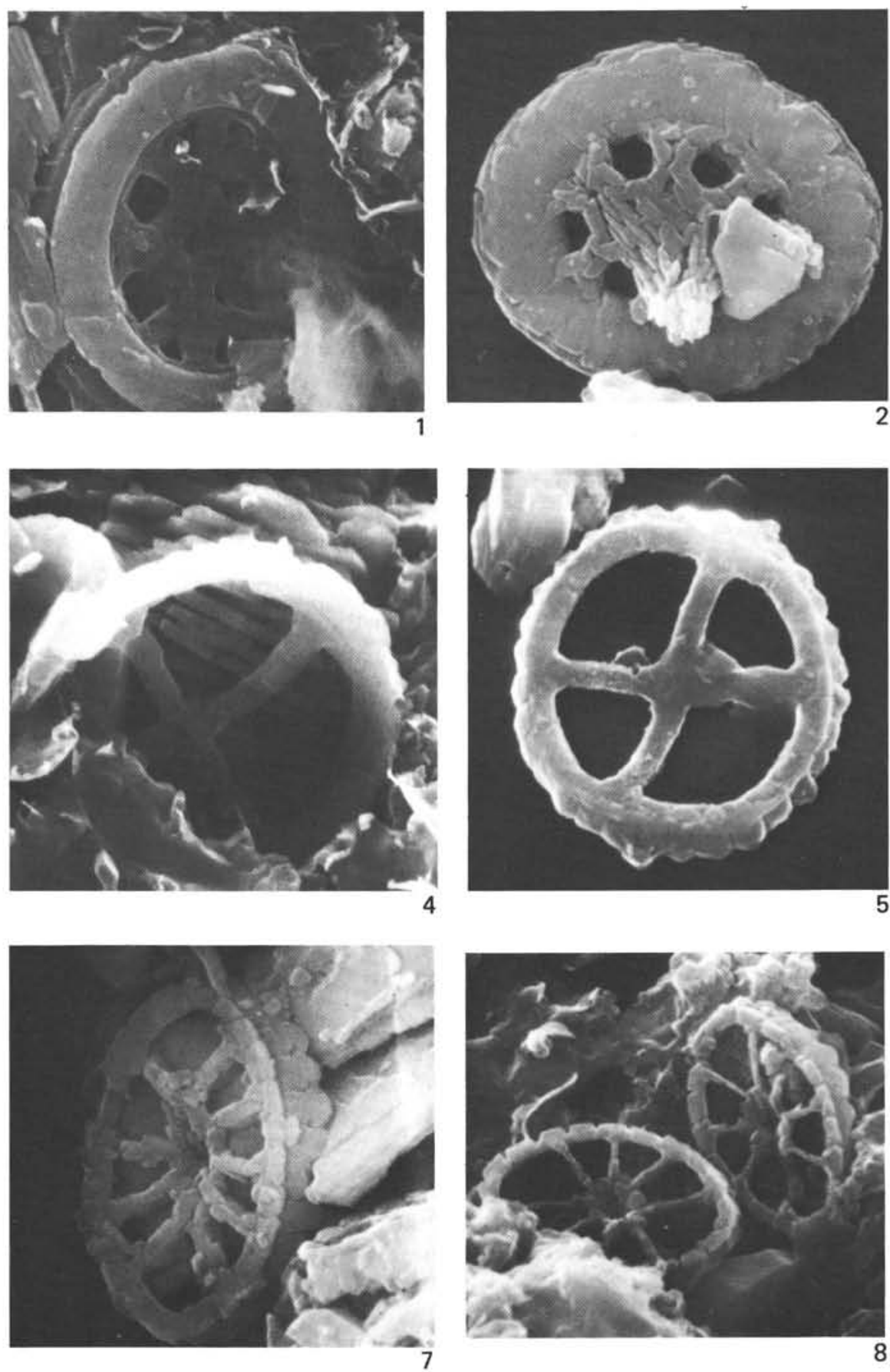

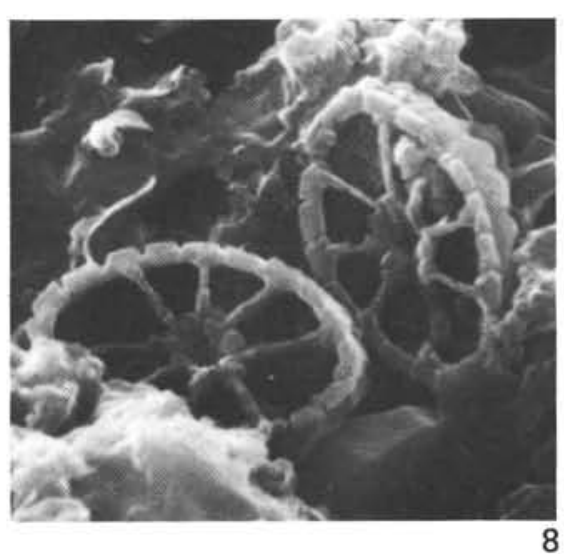

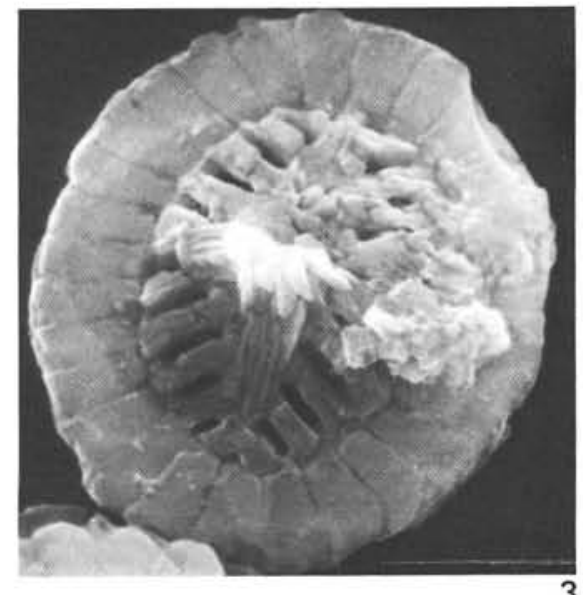
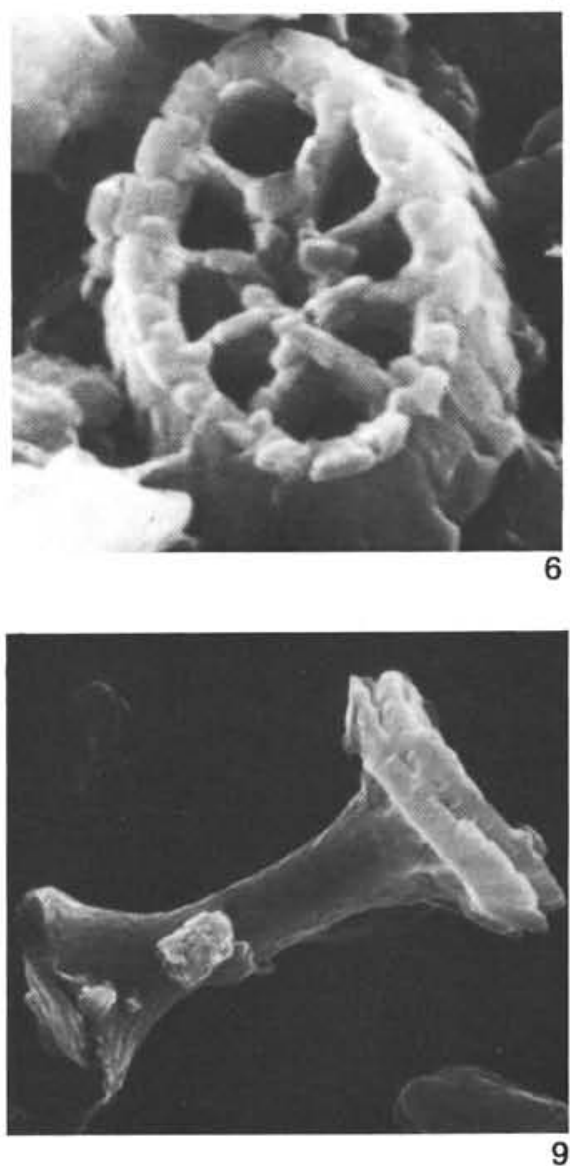

Plate 27. Albian, Aptian. 1. Retacapsa angustiforata (Black) Bukry, P, $\times 12,500$, Aptian Sample 511-57-6, $4 \mathrm{~cm} . \quad 2$. Cretarhabdella bergenii Wise and Wiegand, n. sp., D, $\times 9500$, Aptian Sample 511-59-1, $82 \mathrm{~cm}$. 3. Polypodorhabdus madingleyensis Black, D, $\times 9500$, Aptian Sample 511-59-1, $82 \mathrm{~cm}$. 4-5. Corollithion achylosum (Stover) Thierstein, (4) D, $\times 11,000$, Albian Sample 511-55-6, 32 cm, (5) P, $\times 12,000$, Aptian Sample 511-58-2, $95 \mathrm{~cm}$. 6-8. Corollithion fragilis (Rood and Barnard) Wind and Wise, P, Aptian Sample 511-59-1, 82 cm, (6) $\times 16,500,(7)$ $\times 14,000,(8) \times 9500$. 9. Tetrapodorhabdus decorus (Deflandre and Fert) Wind and Wise, L, $\times 7500$, Aptian Sample 511-58-2, 95 cm. 

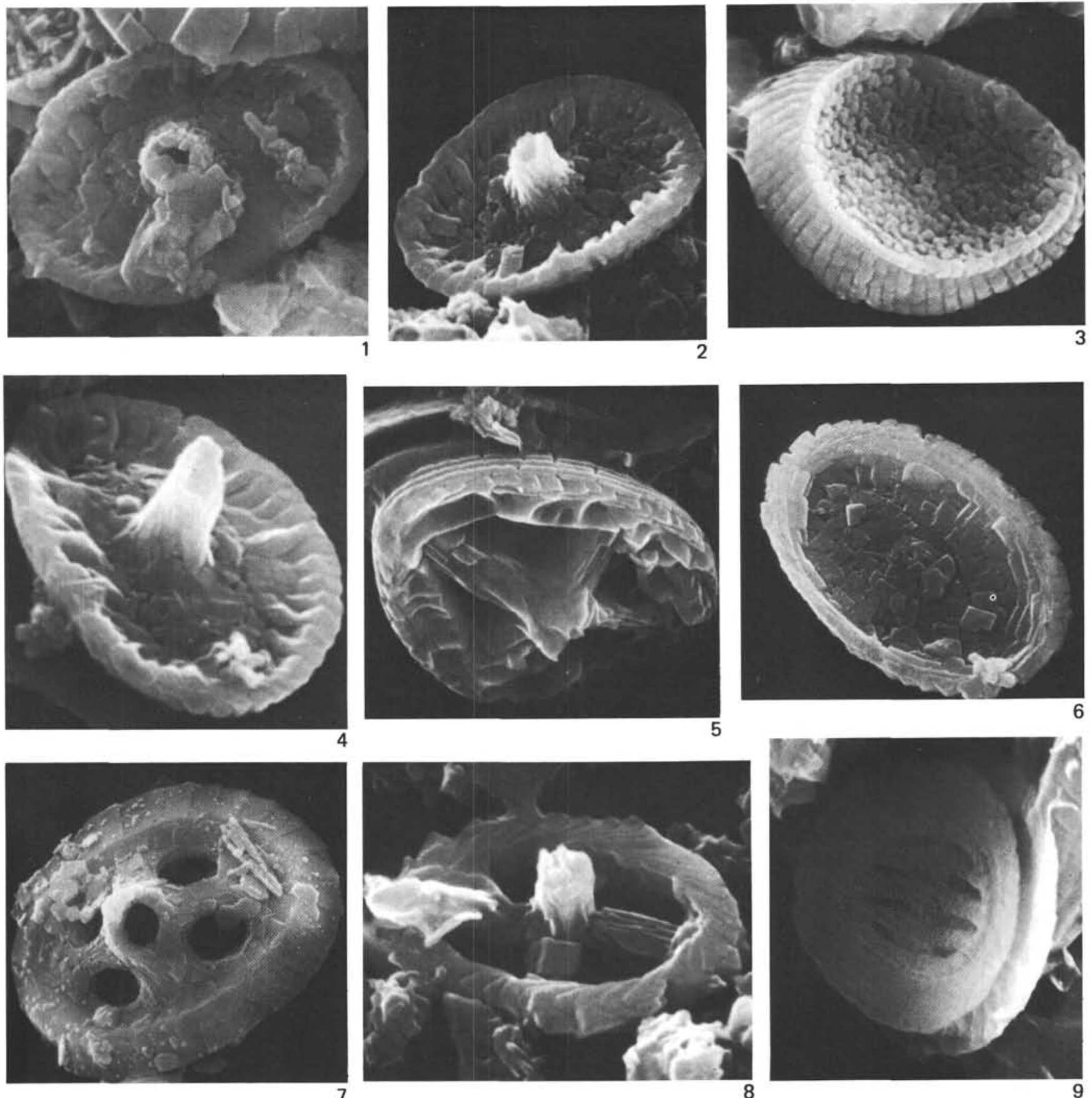

Plate 28. Aptian. 1-4. Rhagodiscus splendens (Deflandre) Verbeek, Sample 511-59-1, $82 \mathrm{~cm},(1) \mathrm{D}, \times 10,500,(2) \mathrm{D}, \times 11,000,(3) \mathrm{P}, \times 10,500$, (4) D, $\times 14,000$. 5. Acaenolithus sp., DL, $\times 11,000$ Sample $511-58-2,77 \mathrm{~cm}$ (from Parker et al., this volume, Pl. 6, Fig. 2). 6. Percivalia fenestrata (Worsley) Wise, n. comb.; D, $\times 7000$, Sample 511-59-1, $82 \mathrm{~cm}$. 7. Axopodorhabdus dietzmanni (Reinhardt) Wind and Wise, D, $\times 7500$, Sample 511-59-1, $82 \mathrm{~cm}$. 8. Vekshinella stradneri Rood, Hay, and Barnard; D, $\times 12,000$, Sample 511-59-1, $82 \mathrm{~cm}$. 9. Sollasites horticus (Stradner, Adamiker, and Maresch) Black, P, $\times 15,000$ Sample 511-58-2, $77 \mathrm{~cm}$ (from Parker et al., this volume, Pl. 5, Fig. 9). 

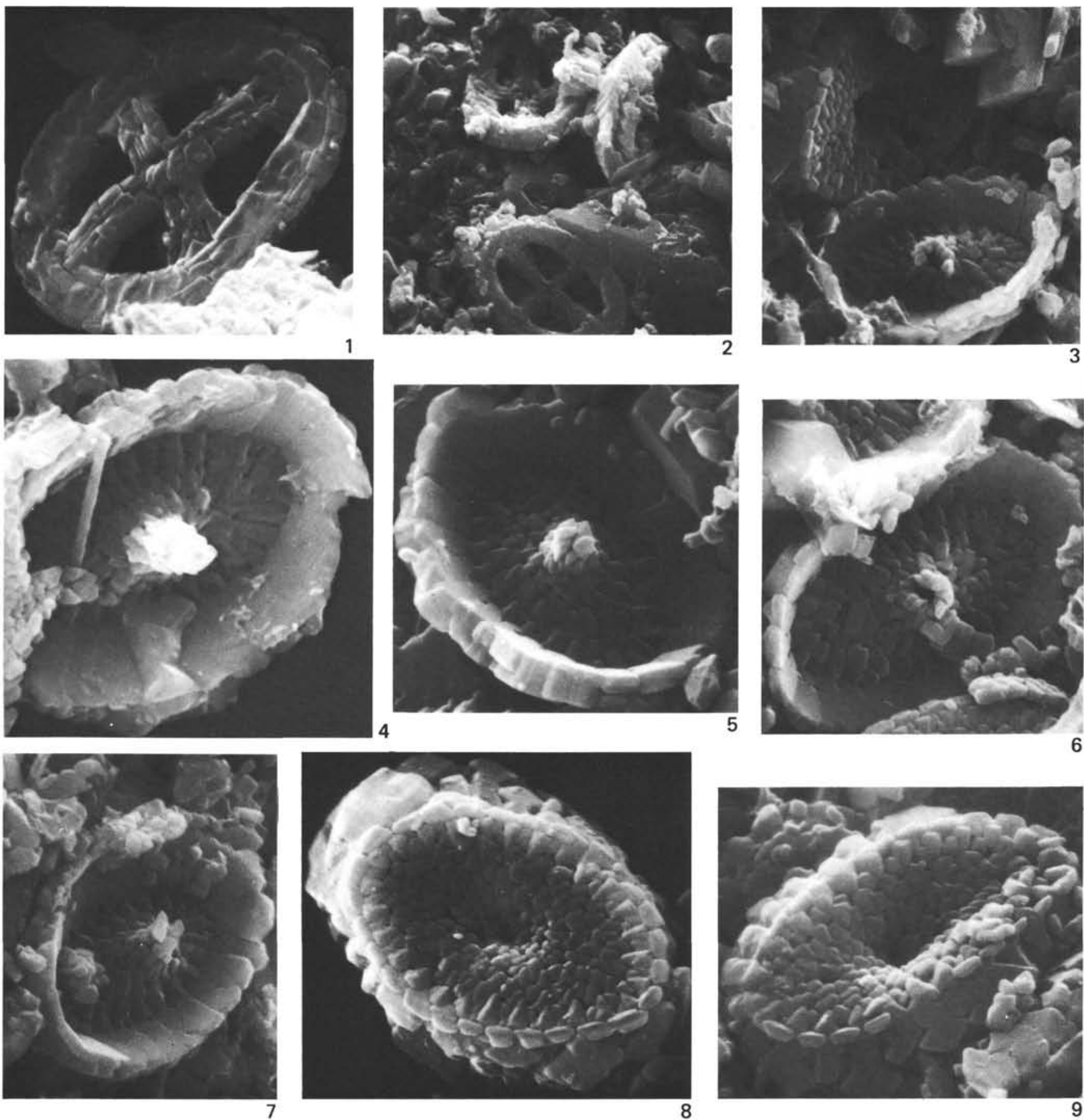

Plate 29. Barremian-Aptian; all from Sample 511-60-1, $76 \mathrm{~cm}$. 1-2. ?Acaenolithus sp., (1) D, $\times 9000$, (2) P, center (upper and lower specimens), $\times 4900$. 3-9. Corollithion silvaradion Filewicz, Wind, and Wise, diagenetically altered specimens, (3) P (upper), D (lower), $\times 8500,(4) \mathrm{D}$, $\times 9500,(5) \mathrm{D}, \times 13,000,(6) \mathrm{D}, \times 11,000,(7) \mathrm{D}, \times 11,000,(8) \mathrm{P}, \times 9500,(9) \mathrm{P}, \times 14,000$. 

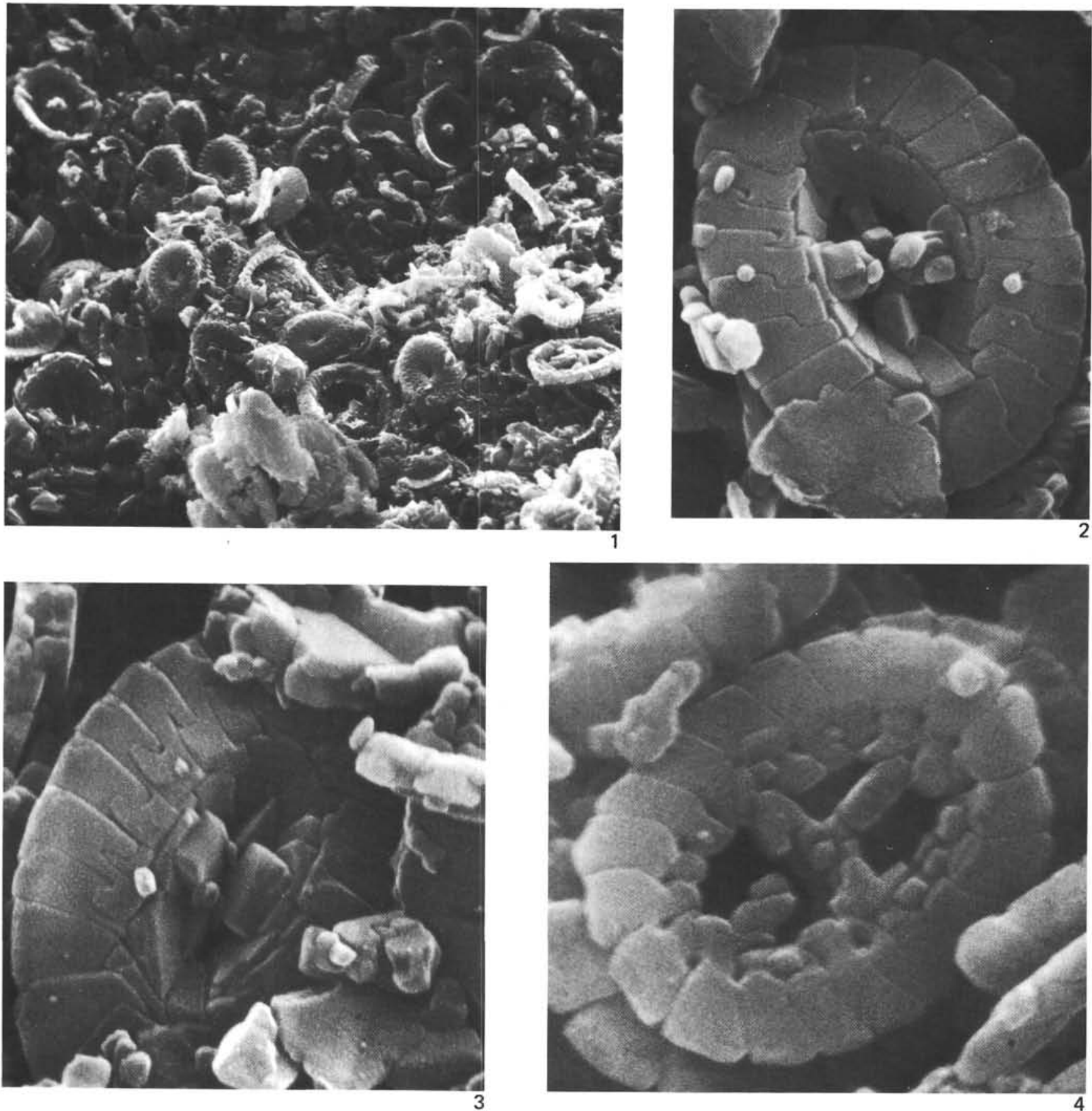

Plate 30. Barremian-Aptian; all from Sample 511-60-1, $76 \mathrm{~cm}$. 1. Corollithion silvaradion Filewicz, Wind, and Wise, large cluster in which a few specimens of Watznaueria barnesae (Black) Perch-Nielsen and Acaenolithus sp. are also present, $\times 2900$. 2-4. Seribiscutum salebrosum (Black) Wise, n. comb., (2) D, $\times 19,000$, (3) $\mathrm{D}, \times 20,500$, (4) $\mathrm{P}, \times 32,500$. 

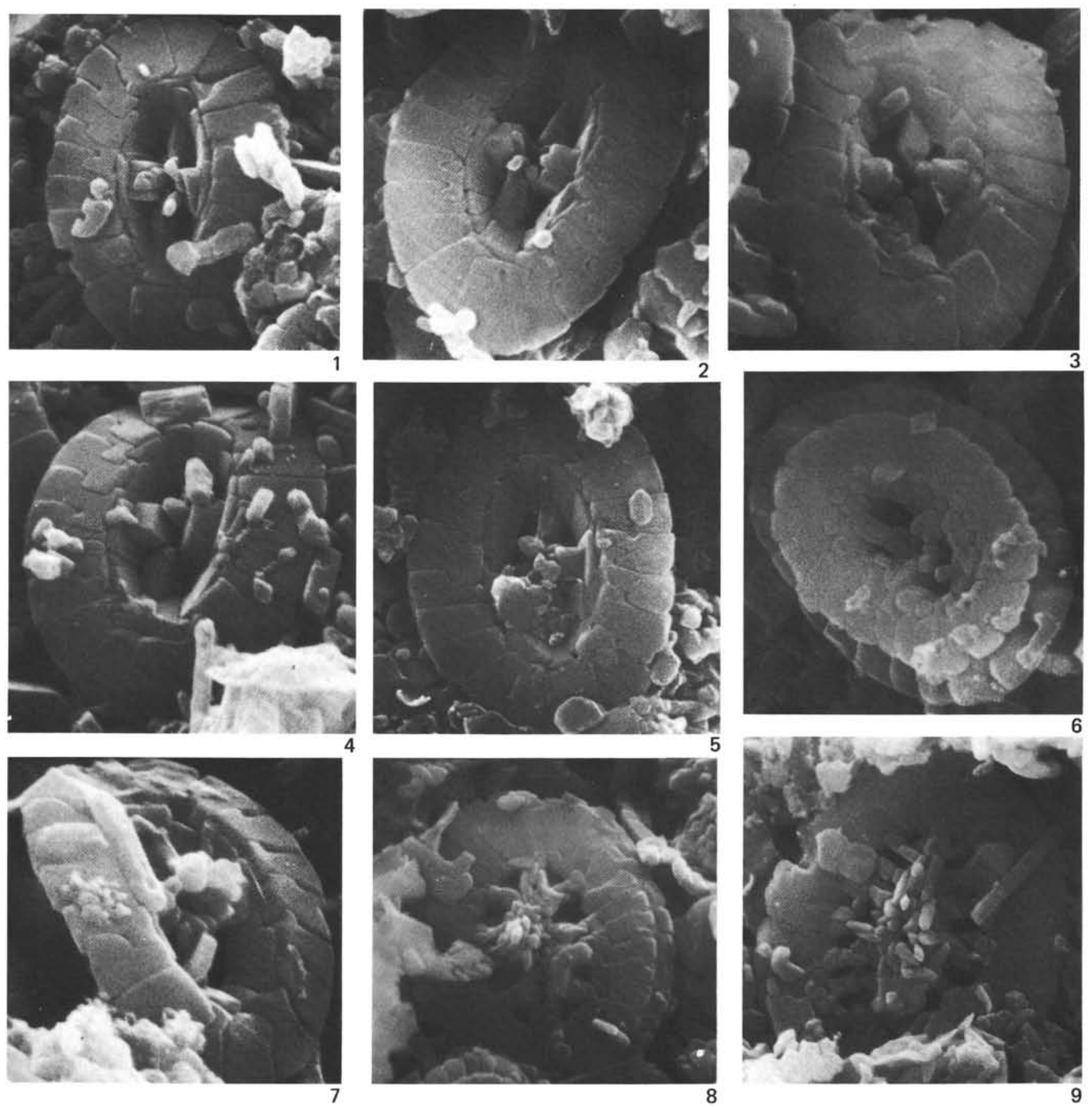

Plate 31. Barremian-Aptian; all from Sample 511-60-1, $76 \mathrm{~cm}$. 1-7. Seribiscutum salebrosum (Black) Wise, n. comb., (1) D, $\times 15,500,(2)$ $\times 15,500$, (3) $\mathrm{D}, \times 20,500$, (4) $\mathrm{D}, \times 16,000,(5) \mathrm{D}, \times 15,500$, (6) $\mathrm{P}, \times 16,000$, (7) $\mathrm{D}, \times 25,000$. 8. Retacapsa angustiforata (Black) Bukry, D, $\times 10,000$. 9. Cretarhabdus conicus Bramlette and Martini, $\mathrm{D}, \times 12,500$. 

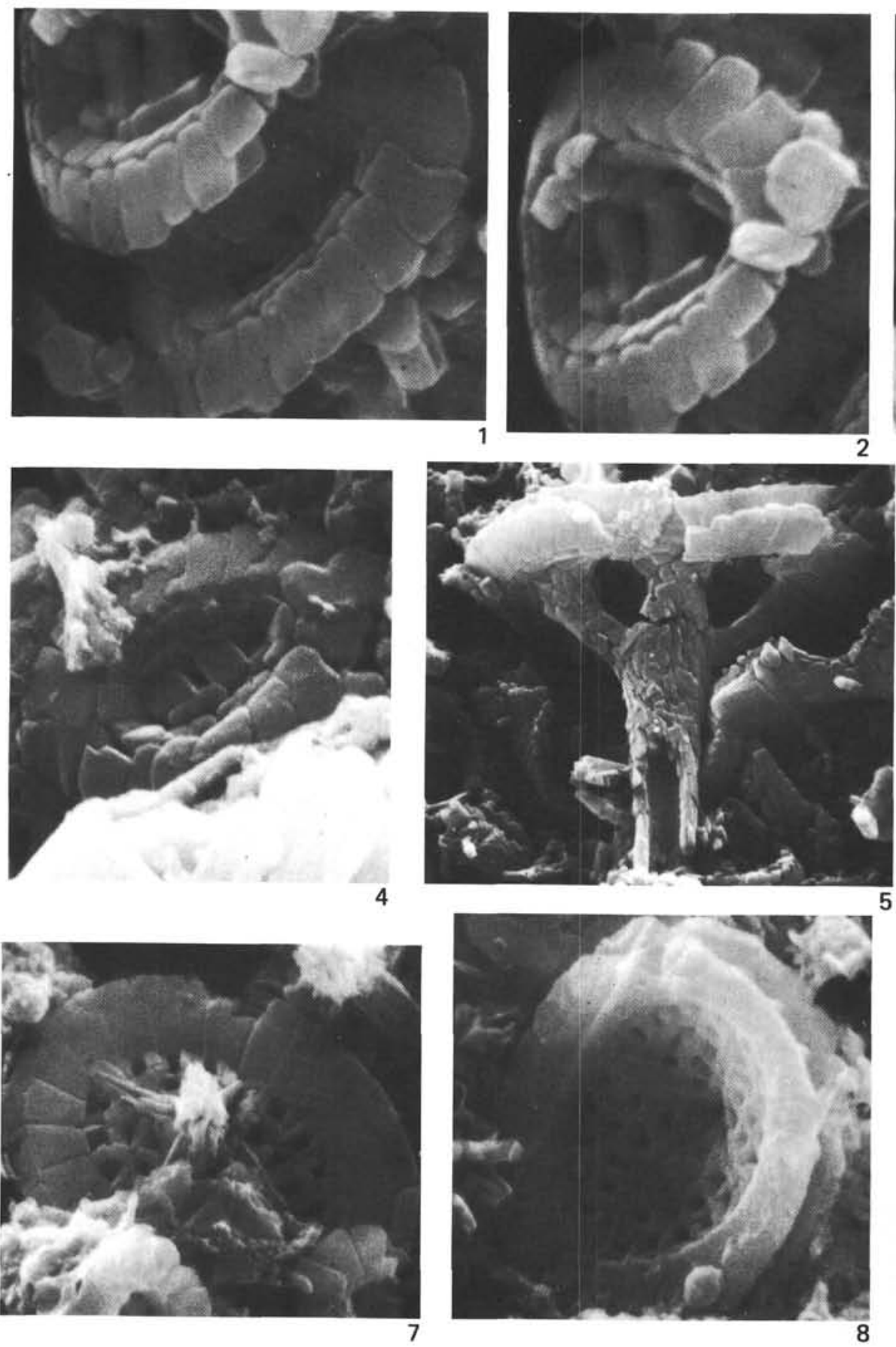
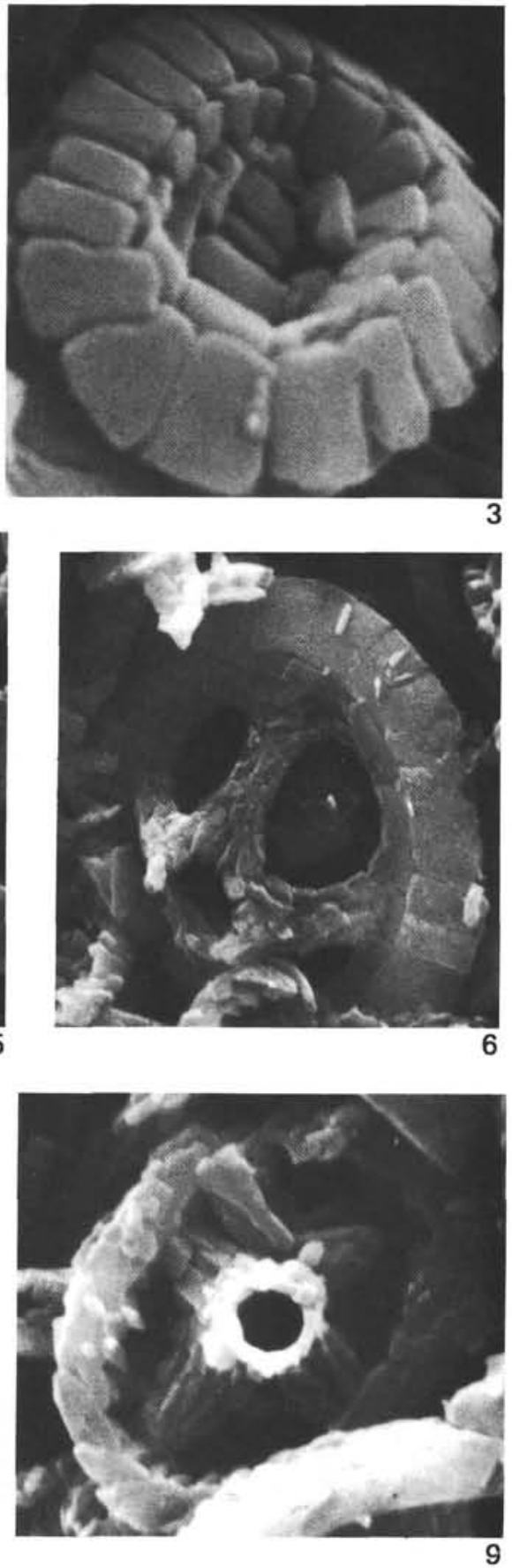

Plate 32. Barremian-Aptian, Neocomian? 1-4. Seribiscutum bijugum Filewicz, Wind, and Wise, D, Barremian-Aptian Sample 511-60-1, 76 cm, (1) $\times 26,000$, (2) $\times 26,500$, (3) $\times 32,500$, (4) $\times 21,500$. 5. Axopodorhabdus dietzmanni (Reinhardt) Wind and Wise, DL, Barremian-Aptian Sample $511-60-1,76 \mathrm{~cm}, \times 6500$. 6. Axopodorhabdus cylindratus (Noël) Wind and Wise, D, $\times 10,000$, Neocomian? Sample $511-61-2,75 \mathrm{~cm}$. 7-8. Cretarhabdus conicus Bramlette and Martini, Neocomian? Sample 511-61-2, $75 \mathrm{~cm}$., (7) D, $\times 14,000,(8) \mathrm{P}, \times 11,000$. 9. Vekshinella quadriarculla (Noël) Noël, D, $\times 17,500$, Neocomian? Sample $511-61-2,75 \mathrm{~cm}$. 

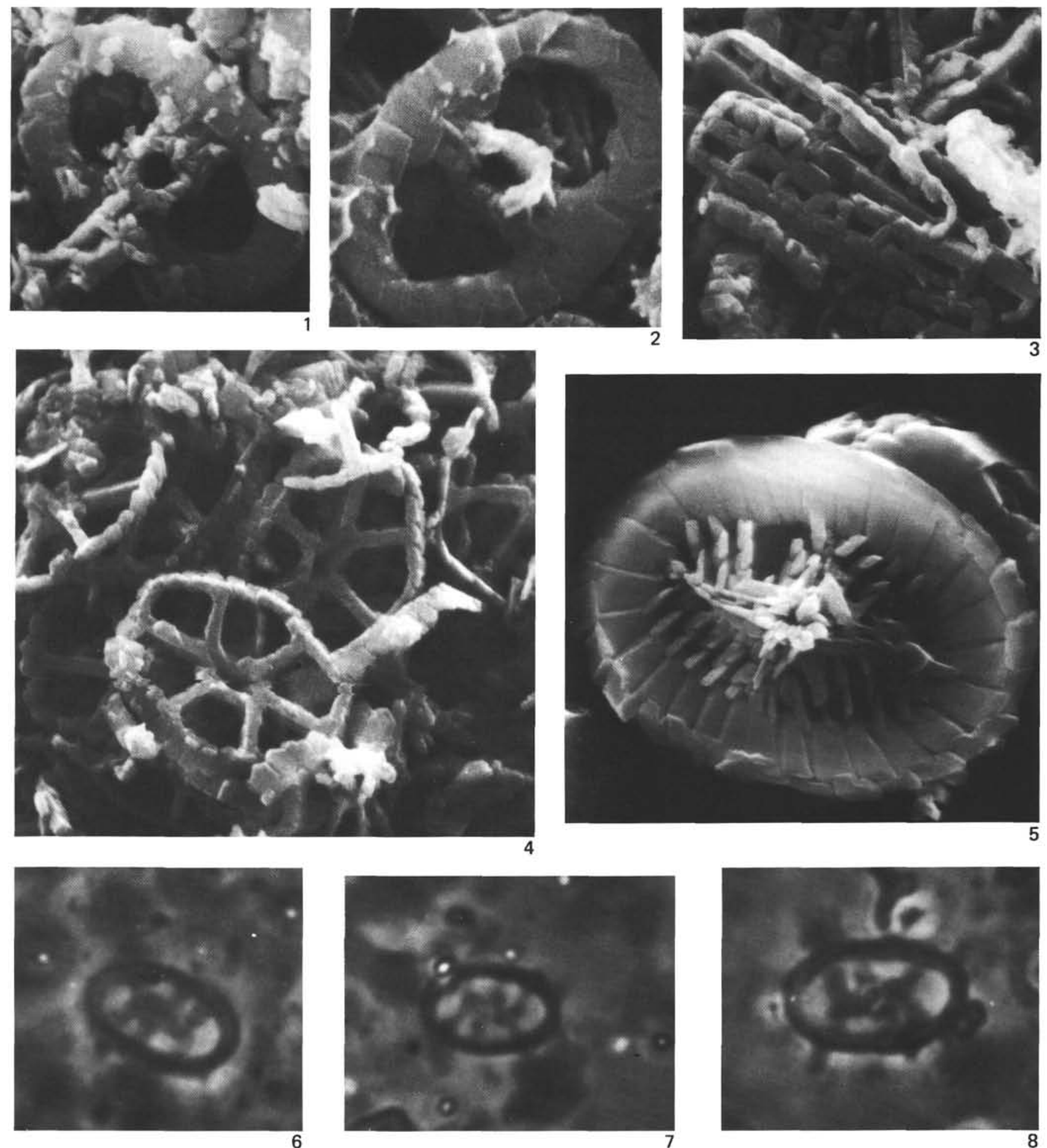

Plate 33. Neocomian?, Jurassic. 1-2. Zeugrhabdotus choffati Rood, Hay, and Barnard, D, Neocomian? Sample 511-61-2, 75 cm, (1) $\times 21,000$,

(2) 22,500. 3. Corollithion delftensis (Stradner and Adamiker) Wise, n. comb., $\times 20,000$, Neocomian? Sample 511-61-2, 75 cm. 4. Corollith-

ion senarius Wind and Wise, $\times 12,000$, Neocomian? Sample $511-61-2,75 \mathrm{~cm}$. 5. Polypodorhabdus escaigi Noël, D, $\times 10,500$, Jurassic Sample 511-66-2, 24 cm. 6-8. Stephanolithion hexum Rood and Barnard, Ph, $\times 6500$, Jurassic Sample 511-70-4, $16 \mathrm{~cm}$. 

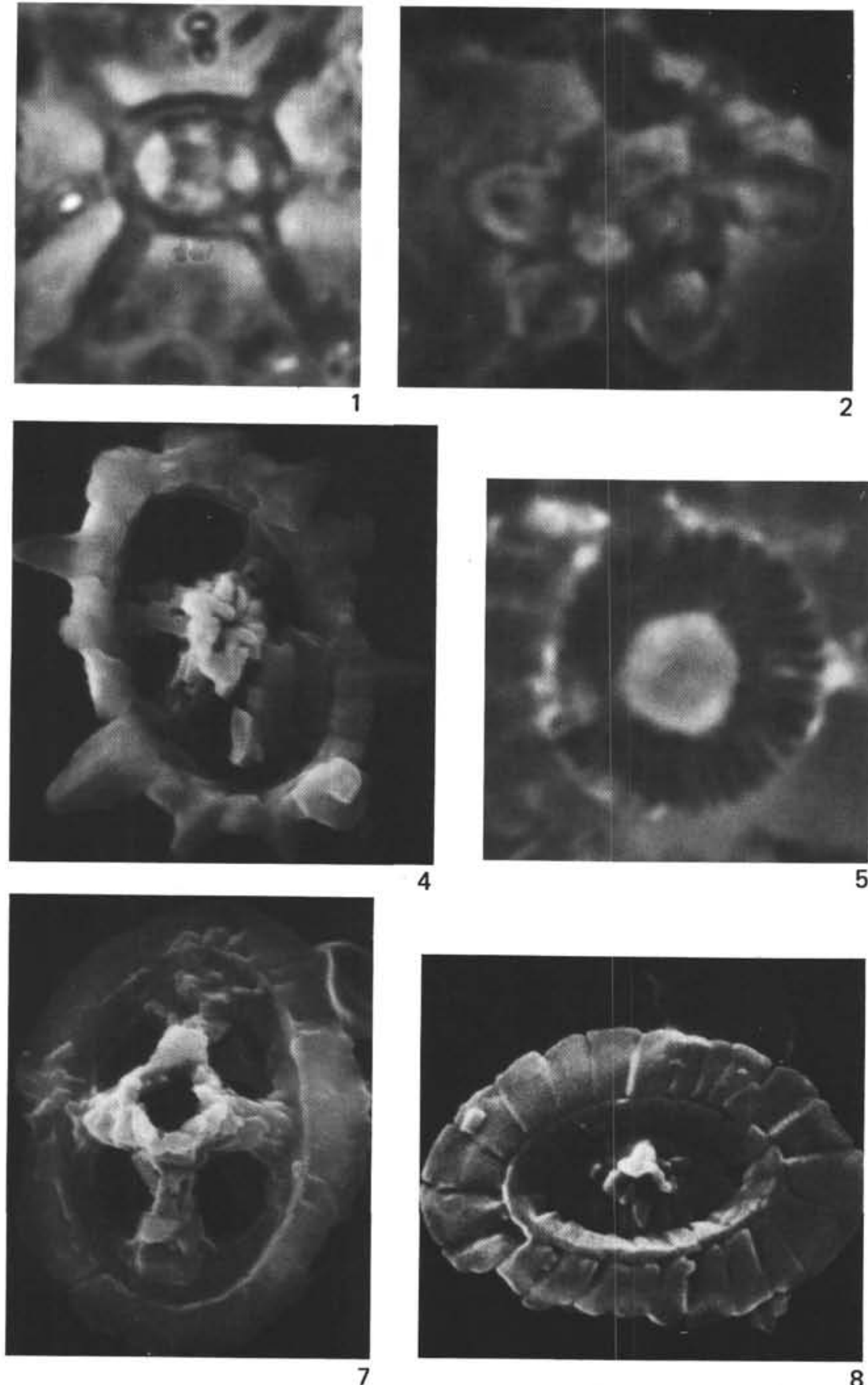

8

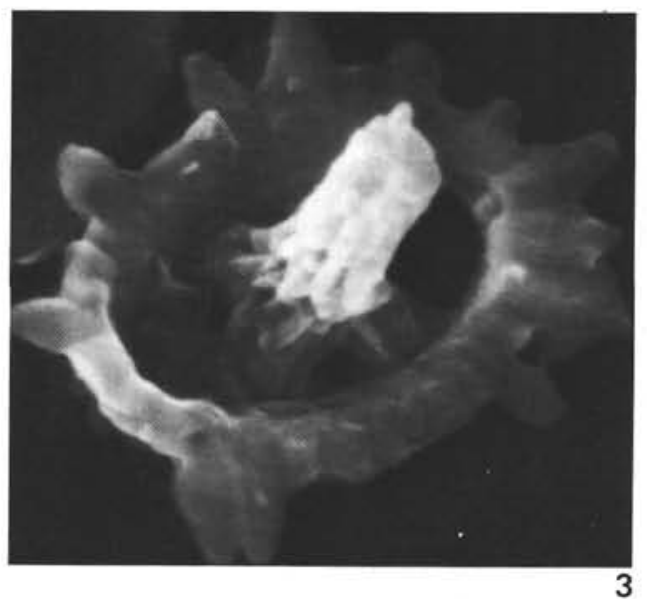

5
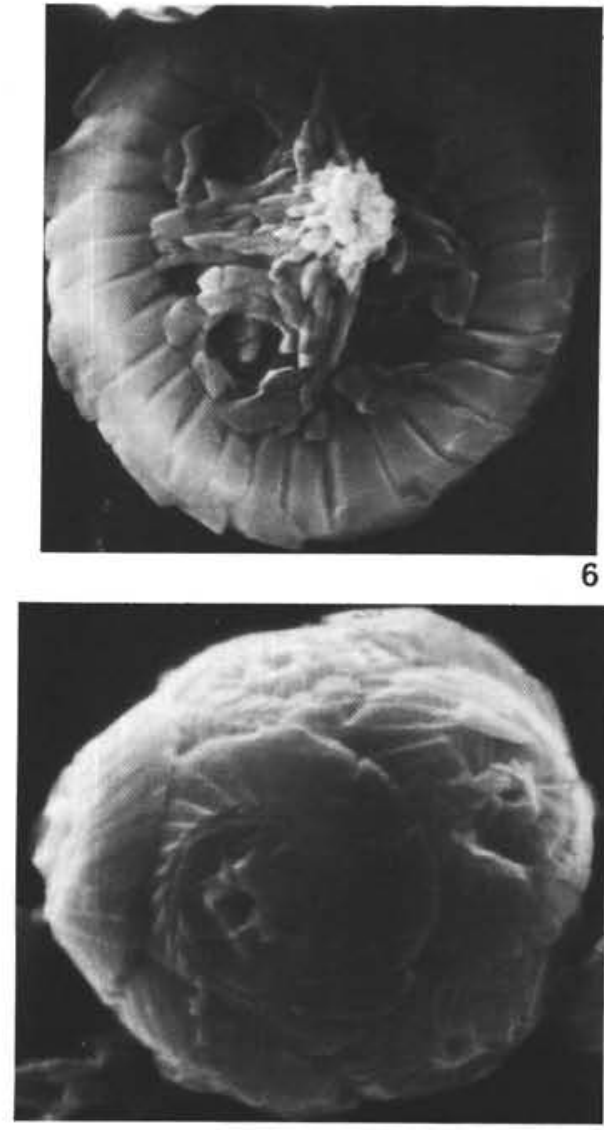

9

Plate 34. Neocomian?, Jurassic. 1-2. Stephanolithion bigoti Deflandre (long lateral spines), $\mathrm{Ph},(1) \times 5500$, Jurassic Sample $511-70-4,16 \mathrm{~cm},(2)$ $\times 6500$, Sample 511-63-2, $64 \mathrm{~cm}$. 3-4. Stephanolithion bigoti Deflandre (short lateral spines), D, Jurassic Sample 511-66-2, 24 cm, (3) $\times 12,000$, (4) $\times 14,500$. 5. Genus et species indet. 3, $\times 7000$, Jurassic? Sample $511-61-4,144 \mathrm{~cm}$. 6. Retacapsa sp. aff. R. angustiforata Black; D, $\times 9500$, Jurassic Sample 511-66-2, $24 \mathrm{~cm}$. 7. Axopodorhabdus cylindratus (Noël) Wind and Wise, D, $\times 7000$, Jurassic Sample 511-66-2, 24 cm. 8. Palaeopontosphaera erismata Wind and Wise, D, $\times 19,000$, Jurassic Sample 511-66-2, $24 \mathrm{~cm}$. 9. Cyclagelosphaera margereli Noël, coccosphere, $\times 6000$, Jurassic Sample 511-66-2, $24 \mathrm{~cm}$. 
S. W. WISE, JR.
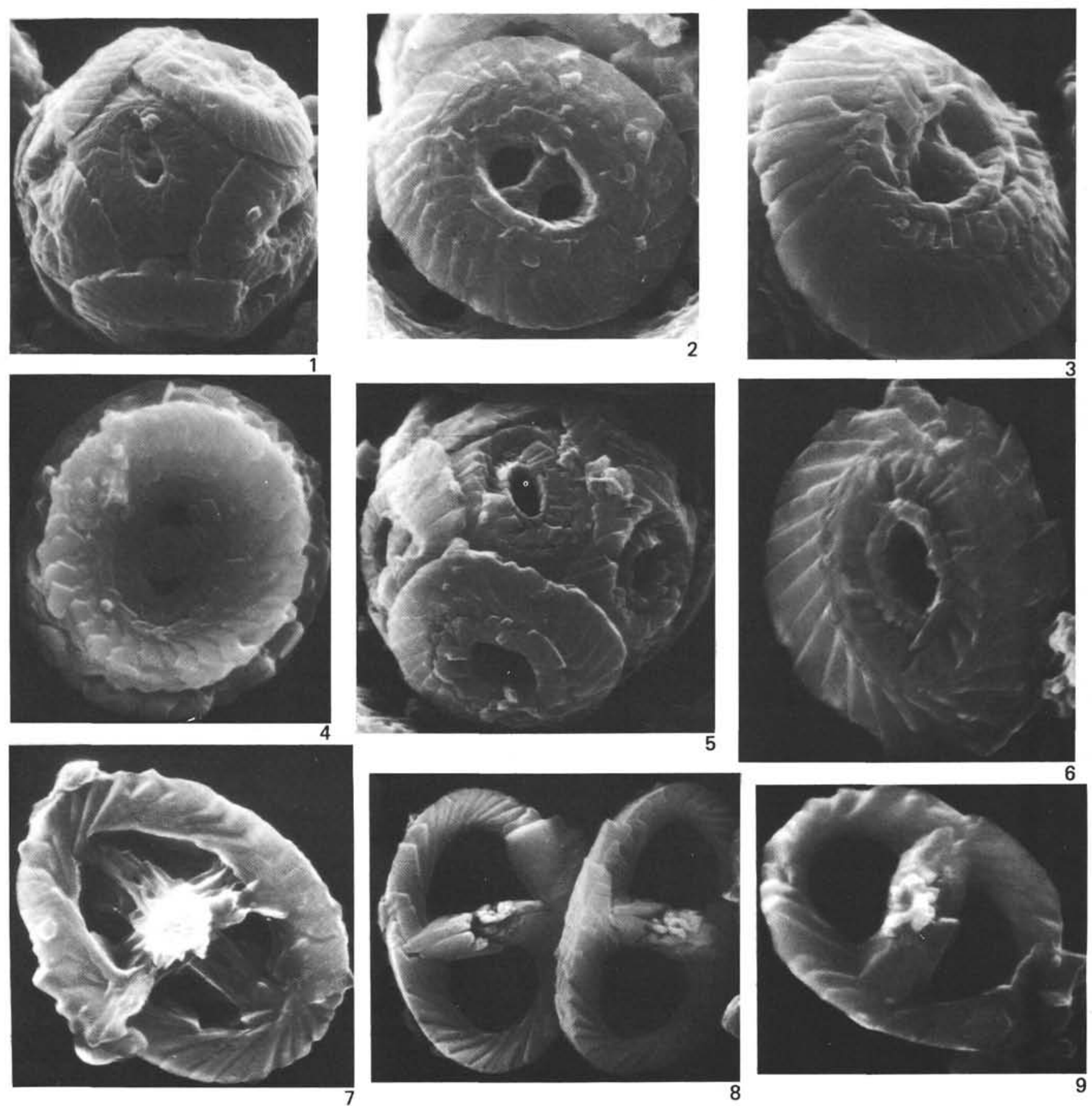

Plate 35. Jurassic; all from Sample 511-66-2, $24 \mathrm{~cm}$. 1-6. Watznaueria britannica (Stradner) Reinhardt, (1) coccosphere, $\times 4500,(2) \mathrm{D}$, specimen resting inside a broken coccosphere, $\times 7000,(3) \mathrm{D}, \times 9000$, (4) $\mathrm{P}, \times 5500,(5)$ coccosphere, $\times 6500,(6) \mathrm{D}, \times 10,000$. 7. Vekshinella stradneri Rood, Hay, and Barnard, D, $\times 12,000$. 8-9. Zeugrhabdotus erectus (Deflandre) Reinhardt, D, $\times 8000$. 